OECDpublishing

SPURRING GROWTH AND

CLOSING GAPS THROUGH

DIGITALISATION IN A POST-

COVID WORLD: POLICIES

TO LIFT ALL BOATS

OECD ECONOMIC POLICY PAPER

November 2021 No. 30 
Economic Policy Paper No. 30

\section{Spurring growth and closing gaps through digitalisation in a post-COVID world: Policies to LIFT all boats}

This paper has been prepared by:

Mauro Pisu

Christina von Rüden

Hyunjeong Hwang

Giuseppe Nicoletti 
The OECD Economic Policy Paper Series is published on the responsibility of the Secretary-General of the OECD. The opinions expressed and arguments employed herein do not necessarily reflect the official views of the Organisation or of the governments of its member countries.

Series: OECD Economic Policy Papers

SSN 2226583X

The statistical data for Israel are supplied by and under the responsibility of the relevant Israeli authorities. The use of such data by the OECD is without prejudice to the status of the Golan Heights, East Jerusalem and Israeli settlements in the West Bank under the terms of international law.

This document and any map included herein are without prejudice to the status of or sovereignty over any territory, to the delimitation of international frontiers and boundaries and to the name of any territory, city or area.

(C) OECD 2021

You can copy, download or print OECD content for your own use, and you can include excerpts from OECD publications, databases and multimedia products in your own documents, presentations, blogs, websites and teaching materials, provided that suitable acknowledgment of OECD as source and copyright owner is given. All requests for public or commercial use and translation rights should be submitted to rights@oecd.org. Requests for permission to photocopy portions of this material for public or commercial use shall be addressed directly to the Copyright Clearance Center (CCC) at info@copyright.com or the Centre français d'exploitation du droit de copie (CFC) at contact@cfcopies.com. 
An earlier version of this paper was discussed at a meeting of Working Party No.1 (WP1) of the OECD Economic Policy Committee.

The authors would like to thank Laurence Boone, Luiz de Mello, Alain de Serres, Dan Andrews, Jon Pareliussen (all from the OECD Economics Department), Cecilia Jona-Lasinio, Valeria Patella, Silvia Sopranzetti (2021 G20 Italian Presidency), OECD colleagues from the Centre for Entrepreneurship, SMEs, Regions and Cities, Directorate for Science, Technology, Directorate for Financial and Enterprise Affairs, Directorate for Employment, Labour and Social Affairs, Statistics and Data Directorate, and participants at the G20 Seminar series organised by the Italian G20 Team in preparation to the 2021 G20 Italian Presidency. The authors would also like to thank Sarah Michelson Sarfati (also from the OECD Economics Department) for excellent editorial support. 


\section{Table of contents}

\section{Spurring growth and closing gaps through digitalisation in a post-COVID world:}

\section{Policies to LIFT all boats}

1. Introduction

2. Digitalisation, elusive productivity gains and increasing wage gaps 10

2.1. Persistent digital divides contribute to curb economy-wide productivity gains 11

2.1. Productivity gaps between frontier and laggard firms are increasing 15

2.1. Digital and productivity gaps contribute to income inequality 21

3. Digitalisation, productivity and incomes in COVID times: challenges and opportunities 21

3.1. The COVID-19 shock offers opportunities to revive productivity growth and narrow inequalities

3.2. COVID-19 poses also new threats to broad-based digital transformation, productivity growth and inclusiveness

4. The right policy mix can accelerate digitalisation and lower income and productivity gaps

4.1. Lifelong learning for all

4.2. Intangible finance for the knowledge economy

3. Framework market conditions for the

4.4. Technology access via digital infrastructure

\section{References}

\section{Tables}

Table 1. Examples of intangible capital and means of protection

\section{Figures}

Figure 1. Linking digitalisation, productivity and income gaps

Figure 2. Productivity growth was already declining before the COVID-19 shock 10

Figure 3. Intangible assets vary markedly across countries 12

Figure 4. Broadband subscriptions vary in terms of coverage and quality 14

Figure 5. Connectivity differs substantially between rural and urban areas and firms of different sizes $\quad 15$

Figure 6. The productivity gap between frontier and laggard firms is increasing 16

Figure 7. Digitalisation is associated with higher sales growth 18

Figure 8. The skill composition differs along the productivity distribution 18

Figure 9. Global skill shortages are high and rising 19

Figure 10. Large firms adopt digital technologies more often than small ones $\quad 19$

Figure 11. Difference in average wages among firms explain a large share of overall wage inequality 21

Figure 12. Pandemics lower labour productivity growth 22

Figure 13. Intangible and digital-intensive firms were more resilient to the COVID-shock

Figure 14. The decline in job vacancies was lower for firms with a high share of jobs amenable to telework 24 
Figure 15. Levels of telework have skyrocketed

Figure 16. Online platform growth before and during COVID 25

Figure 17. Stock market returns surged for firms with a strong digital presence 226

Figure 18. SMEs recognize the importance of digitalisation but face critical challenges 27

Figure 19. The magnitude of job losses has been larger for low-skilled workers 31

Figure 20. A range of policies can support productivity through digital adoption 32

Figure 21. Coverage of adult learning systems 33

Figure 22. Gap in participation by socio-demographic characteristics $\quad 34$

Figure 23. Training the low-skilled contributes strongly to digital diffusion $\quad 35$

Figure 24. SMEs provide less ICT training for their staff 36

Figure 25. Socio-economic profiles still largely explain educational outcome gaps 38

Figure 26. Policy options to make financial systems fit for the rise in intangible investment 41

Figure 27. Improving financial systems to harness the growth opportunities associated with intangible assets 42

Figure 28. Market concentration has increased in Europe and North America 43

Figure 29. Estimated effect of the proposals on tax revenues, by jurisdiction groups 45

Figure 30. The digital transformation of governments is underway but much remains to be done 50

Figure 31. Increase in domestic bandwidth production across G20 countries $\quad 51$

Figure 32. High-speed broadband is associated with higher productivity 52

\section{Boxes}

Box 1. Innovations and productivity growth: the long view

Box 2. Recent evidence on the effects of patents on innovation and technology diffusion 20

Box 3. Lifelong learning - selected policy actions 39

Box 4. Intangible investment - selected policy actions $\quad 42$

Box 5. Framework conditions - selected policy actions $\quad 51$

Box 6. Technology access - selected policy recommendations $\quad 54$ 


\section{Spurring growth and closing gaps through digitalisation in a post-COVID world: Policies to LIFT all boats}

The full potential of digital technologies remains unrealised and their benefits unequally shared because of insufficient investment in enabling intangible assets and communication networks within and across countries. The COVID-19 shock poses new challenges and opportunities. Drawing on past and ongoing OECD work, the paper proposes a multipronged policy approach to durably accelerate the diffusion and uptake of digital technologies across all layers of society, and share their benefits more widely. The building blocks of the proposed LIFT approach include: Lifelong learning for all to ensure everybody has the opportunity to acquire and upgrade the skills needed to thrive in a digital world; Intangibles finance for the knowledge economy to allow more firms, especially small ones, to increase intangible investment and seize the opportunities offered by the digital transformation; Framework market conditions for the digital age to upgrade policies to the digital age, especially in the areas of taxation, competition law and enforcement, digital security, firms' entry and exit, and e-government; Technology access via digital infrastructure to facilitate access to communication networks and accelerate the take up of digital technologies and their international diffusion.

JEL classification codes: L25, L4, O32, O33, O38, I240, J3.

Keywords: Firm Growth, Firm Performance, SME, Competition Policy, Technology Adoption, Technology and Competitiveness, Skill Biased, Innovation Policy, Education and Inequality, Compensation, Wages.

\section{Stimuler la croissance et réduire les fractures grâce au numérique dans un monde post- COVID : adopter l'approche « FFCA » au bénéfice de tous}

Le potentiel des technologies numériques n'est toujours pas pleinement exploité, et leurs avantages sont inégalement répartis en raison d'investissements insuffisants en faveur des actifs incorporels et des réseaux de communication au niveau national et international. Le choc lié au COVID-19 soulève de nouveaux problèmes et ouvre de nouvelles perspectives. En nous fondant sur des travaux antérieurs et en cours de l'OCDE, nous proposons dans ce document une approche pluridimensionnelle pour accélérer durablement la diffusion et l'adoption des technologies numériques dans tous les pans de la société, et faire en sorte que leurs fruits soient plus largement partagés. L'approche «FFCA » proposée ici repose sur les piliers suivants : la formation tout au long de la vie pour tous, pour garantir à chacun la possibilité d'acquérir et d'améliorer les compétences nécessaires pour prospérer dans un monde numérique ; le financement des actifs incorporels nécessaires à l'économie du savoir, pour permettre à davantage d'entreprises, en particulier aux petites, d'accroître leurs investissements immatériels et d'exploiter les possibilités offertes par la transformation numérique ; des conditions-cadre des marchés adaptées à l'ère du numérique, pour que les politiques publiques soient en phase avec l'essor du numérique, en particulier dans les domaines de la fiscalité, du droit de la concurrence et de son application, de la sécurité numérique, de l'entrée et de la sortie des entreprises du marché, ainsi que de l'administration électronique ; et l'accès aux technologies via les infrastructures numériques, pour faciliter l'accès aux réseaux de communication et accélérer l'adoption des technologies numériques et leur diffusion internationale.

Classification JEL: L25, L4, O32, O33, O38, I240, J3.

Mots clés : croissance des entreprises, performances des entreprises, PME, politique de la concurrence, adoption des technologies, technologie et compétitivité, biais en faveur des travailleurs qualifiés, politique de l'innovation, éducation et inégalités, rémunération, salaires. 


\section{Main findings}

This paper reviews the state of knowledge on progress in digitalisation and its impact on growth and gaps in productivity and incomes. Digital technologies can support productivity growth but their full potential remains unrealised and their benefits unequally shared because of insufficient investment in enabling intangibles assets (including R\&D, organisational capital, management skills, ICT skills) and uneven access to communication networks within and across countries.

The COVID-19 shock generates new challenges and opportunities for the digital transformation to revive productivity growth and contribute to narrowing productivity and income gaps. On the one hand, COVID-19 and some of the policies implemented to soften its impact on people and firms can further slow productivity growth and lead to a more uneven distribution of the benefits of the digital transformation. On the other hand, COVID-19 offers opportunities to redesign policies in a vast range of areas, which can not only durably accelerate the digital transformation but also lead to a wider sharing of its economic benefits.

Which of these scenarios will prevail in the post-COVID-19 world is uncertain as COVID-19 is still unfolding and much will depend on the kind and effectiveness of policies countries will implement in the recovery period. Drawing on past and ongoing OECD work, the paper proposes a multipronged policy approach to durably accelerate the diffusion and uptake of digital technologies across all layers of society, and share their benefits more widely. The building blocks of the proposed LIFT approach are the following:

- Lifelong learning for all. Skills are crucial to adopt and effectively use digital technologies; Building effective and inclusive lifelong learning programmes is key to ensuring everybody has the opportunity to acquire and upgrade the skills needed to thrive in a digital world. This hinges on boosting adult learning programmes and on-the-job training schemes, through awareness campaigns and targeted financial incentives, and better integrating digital tools into school curricula aimed at developing cognitive and non-cognitive skills.

- Intangibles finance for the knowledge economy. Intangible assets (such as managerial talent, software and R\&D) are an essential complement to the digital transformation. Easing financial frictions, accelerating the development of equity markets and providing more generous and targeted support to intangible investment can allow more firms, especially small ones, to increase intangible investment and seize the opportunities offered by the digital transformation.

- Framework market conditions for the digital age. Digitalisation has been concomitant with a widespread decline in business dynamism and increasing market concentration, especially in digital-intensive industries. Reversing these trends requires policies fit for the digital age, especially in the areas of taxation, competition law and enforcement, digital security, firms' entry and exit, and e-government. Progress in these areas can secure a level-playing field and market openness, promote business dynamism and increase trust in the digital economy.

- Technology access via digital infrastructure. Digital infrastructure is a necessity for participating in economic and social life and exploiting the opportunities digital technologies offer. However, access to communication networks is still uneven within and between countries, hampering the take up of digital technologies and international technology diffusion. Fiscal incentives to encourage private investment in underserved areas, direct public investment where private investment is not commercially viable, and ensuring competition in telecommunication markets would improve and widen access to communication networks and support the digital transformation everywhere. 


\section{Spurring growth and closing gaps through digitalisation in a post-COVID world: Policies to LIFT all boats}

\section{Introduction}

1. Digital technologies offer a vast potential to enhance welfare and living standards by raising product and service quality, and productivity growth. However, it is widely acknowledged that much of this potential is yet to be realised, as reflected by the productivity slowdown many countries experienced over the past 20 years. Moreover, concerns have emerged that digitalisation is contributing to widen performance and income gaps across firms and workers. The COVID-19 crisis has heightened these concerns as the capacity to benefit from the acceleration in the digital transformation caused by the COVID19 shock varies across firms and individuals.

2. Public policies need to ensure that the digital transformation sustains growth while contributing to closing income and productivity gaps. Drawing on a large body of research, including OECD work, this paper aims at summarising current knowledge on the drivers of digitalisation, its role in widening firms' performance and income gaps and what policies can do to support a strong and inclusive digital transformation. Fully realising the benefits of digital technologies and sharing them widely across and within countries requires appropriate market incentives to widen digital adoption and increase investment in complementary factors (such as communication networks) and intangibles assets (such as organisational capital, cognitive and non-cognitive skills, data, software and R\&D). Moreover, rapid advances in digital technologies (e.g. artificial intelligence) will make these complementary factors even more important in the future, as the demand for high-speed communication networks increases and human-machine interactions become more complex and pervasive.

3. Digital technologies have been spreading rapidly but many obstacles still hamper their wider adoption and effective use. These include uneven access between and within countries to communication networks and intangible assets. As a result, as discussed in Section 2, digital technologies' reach and benefits vary significantly across firms, socio-economic groups and countries. Large digital divides persist between advanced and emerging-market economies, urban and rural areas, large and small firms, highand low-skilled individuals, hindering strong and inclusive growth. Small and low productive firms often fail to adopt digital technologies in the first place and, when they do, they are unable to reap their full benefits. This is especially problematic in economies where micro and small firms, and informal activity, account for a large share of employment and output. Persistent digital divides contribute to productivity gaps between firms at the technology frontier and those lagging behind. In turn, this weighs on aggregate productivity growth and widens differences in average wages between firms, contributing to wage and income inequality (Figure 1) (Criscuolo et al., 2020[1]; OECD, 2020[2]).

4. The COVID-19 shock adds new difficult challenges and risks, potentially aggravating these trends. As discussed in Section 3, the fall in investment and international trade, lower mobility of workers across sectors and firms, erosion of unemployed workers' human capital and students' educational losses because of school closures jeopardise long-term growth prospects and inclusiveness. In the shorter term, firms and households who were less familiar with digital technologies have been less resilient during the crisis. Initial data show that young people, low-skilled and non-standard workers (i.e. informal, selfemployed and part-time workers) have experienced starker income losses (OECD, 2020[3]). At the same 
time small firms and those with no or low intangible capital face higher risks of distress and failure (Demmou et al., 2021[4]).

5. With appropriate policies, however, the COVID-19 shock offers opportunities to expedite the digital transformation and share its benefits more widely (OECD, 2020 $\left[{ }_{[5]}\right)$. Digitalisation processes - previously hampered by inertia, lack of vision, urgency, or budget - have suddenly become necessary to implement governments' emergency responses and allow many people and firms to keep working and producing during lockdowns. Drastic surges in the number of people teleworking, the large rise in online platforms' activity and e-commerce, and the continuity of access to public services during lockdowns are a testament to these changes (OECD, 2020[6]; OECD, 2021 [7]]; OECD, 2021 [8] ).

Figure 1. Linking digitalisation, productivity and income gaps
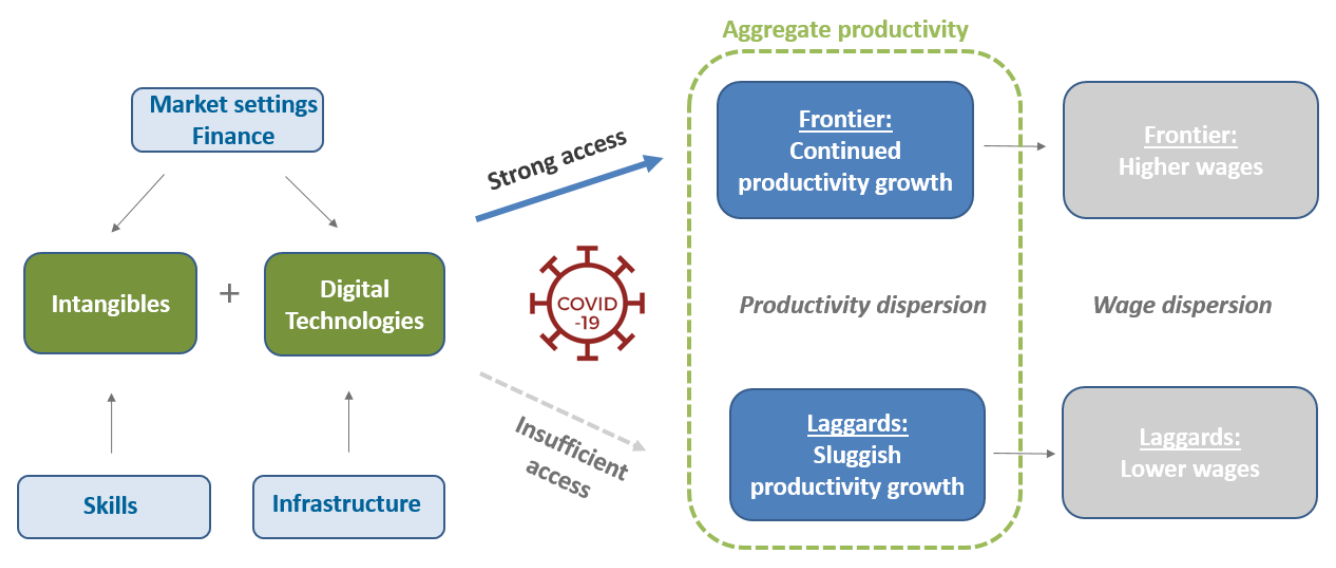

Source: OECD.

6. The COVID-19 shock has pushed many OECD and G20 countries to implement a range of - often overdue - policies aiming at accelerating the digitalisation of public and private-sector activities. These include improving broadband connectivity, helping firms to adopt online business models, promoting online payments and digital government services, and enhancing digital skills. Building synergies among this wide range of policies and interventions requires careful coordination across policy areas.

7. To tackle the interlocking challenges and seize opportunities this paper puts forward, based on past and ongoing work across OECD directorates, a comprehensive approach to accelerate the diffusion of digital technologies. The key elements of the proposed LIFT approach are the following:

- Lifelong learning for all: As skills are key to the successful adoption of digital technologies, policymakers should step up efforts to increase participation in adult learning programmes and on-thejob training, and effectively integrate digital tools and skills into school systems also through better teacher training (OECD, 2020[9]).

- Intangibles finance for the knowledge economy: To enhance firms' investment in intangible assets, which are complementary to the digital transformation, policies should aim at easing financial frictions, accelerating the development of equity markets and providing public support to intangible investments where needed (Demmou and Franco, 2021 ${ }_{[10]}$ ).

- Framework market conditions for the digital age: Innovation and access to markets are key to a broad-based digital transformation. Yet, digitalisation has been concomitant with a widespread decline in business dynamism and increasing market concentration, especially in digital-intensive industries. This calls for policies fit for the digital age, especially in the areas of taxation, competition law and enforcement (OECD, 2020[11]; OECD, 2020[12]), digital security (OECD, 2019[13]; OECD, 
$\left.2020_{[14]}\right)$, firm entry and exit (OECD, 2020[15]; OECD, 2020[16]), and digital government (OECD, $2020[17])$. Progress in these areas is crucial to secure a level-playing field, ensure market openness and promote business dynamism while enhancing trust in digital technologies.

- Technology access via digital infrastructure: More than ever before, universal connectivity is key to participating in economic and social life (OECD, 2020[18]), but access to communication infrastructure is still uneven, slowing down digitalisation and abetting inequalities. Policy interventions, such as fiscal incentives to encourage private investment in underserved areas or direct public investment where it is not commercially viable, leveraging public procurement strategies for the supply of digital infrastructure while ensuring competition in telecommunication markets would widen access to communication networks and support the digital transformation (OECD, 2020[5]).

\section{Digitalisation, elusive productivity gains and increasing wage gaps}

8. COVID-19 has hit while the global economy was already grappling with a persistent productivity slowdown. In most advanced economies, yearly productivity growth had been around or below $1 \%$ for the past fifteen years (Figure 2, Panel A and B). In some emerging-market economies productivity growth had been stronger, but the global financial crisis significantly slowed down their productivity convergence towards advanced economies (Figure 2, Panel C). COVID-19 could be a further threat to global productivity dynamics (di Mauro and Syverson, 2020[19]) and its economic consequences risk entrenching the productivity divide between advanced and emerging-market economies.

\section{Figure 2. Productivity growth was already declining before the COVID-19 shock}

Panel A: OECD, G20 - GDP per hour worked, percentage Panel B: OECD, G20 - GDP per person employed, rate at annual rate percentage rate at annual rate
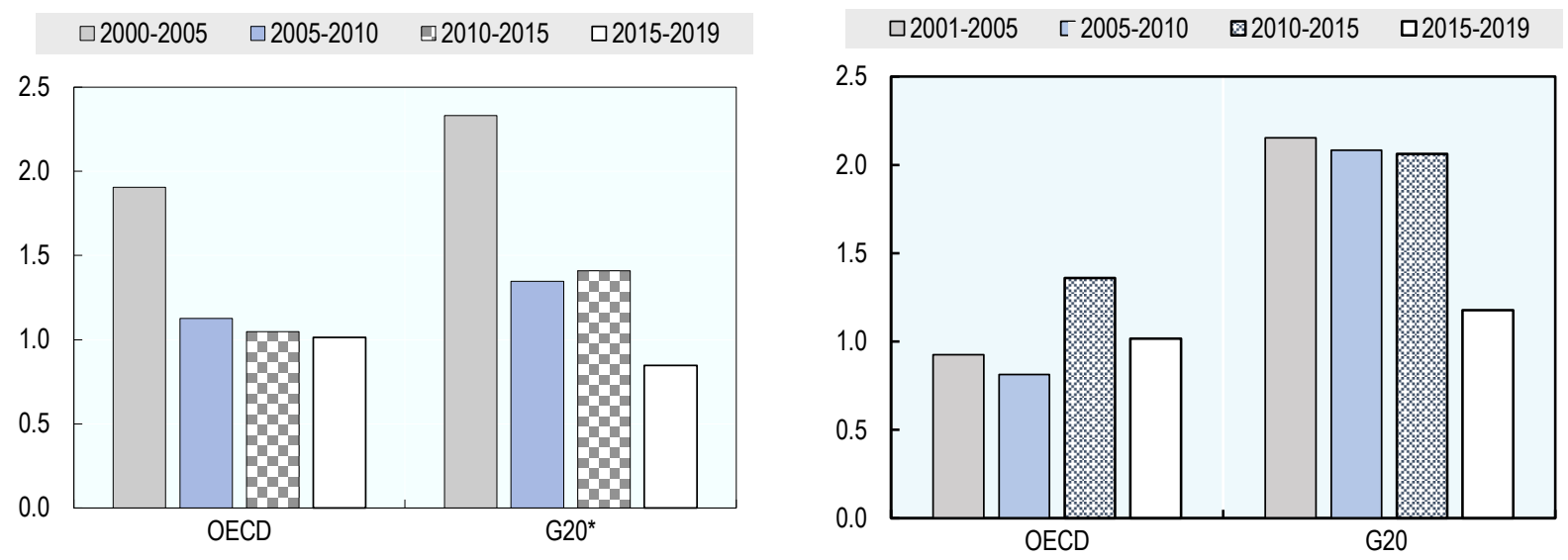
Panel C: BRIICS economies - GDP per person employed, percentage change at annual rate

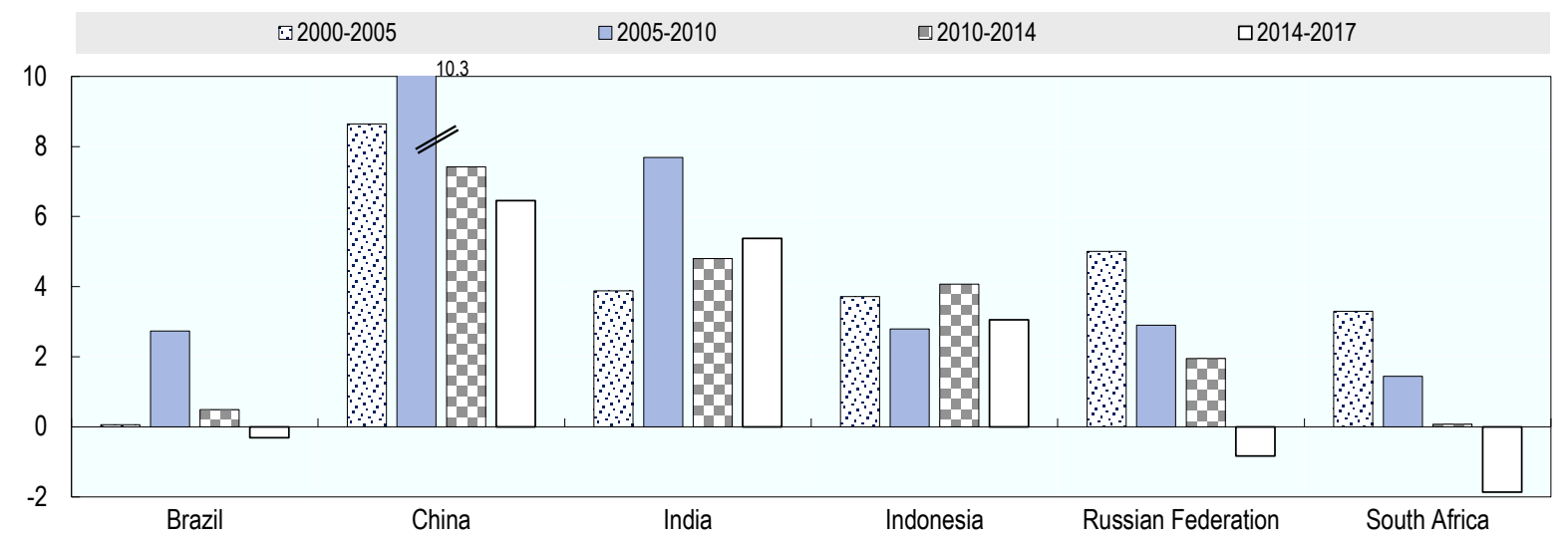

Source: OECD $\left(2019_{[20]}\right)$ based on OECD Productivity Statistics (database) http://dx.doi.org/10.1787/pdtvy-data-en, Economic Outlook database, and World Bank indicators https://data.worldbank.org/indicator/SP.POP.TOTL. ${ }^{*} 15$ G20 members for which data was available (Australian, Canada, European Union, France, Germany, Italy, Japan, Korea, Mexico, New Zealand, Russia, South Africa, Turkey, United Kingdom, and United States).

\subsection{Persistent digital divides contribute to curb economy-wide productivity gains}

9. The productivity slowdown is, at first glance, puzzling as it has occurred at a time of rapid advances in digital technologies. Digital technologies can lead to efficiency improvements through a variety of channels (Syverson, 2011[21]; Goldfarb and Tucker, 2019[22]). They lower transaction costs in market exchanges (e.g. acquisition and use of information, matching of buyers and suppliers, search and transport costs, tracking and verification), allow firms to innovate (both products and processes, for instance by automating routine tasks) and scale up rapidly best practices (e.g. by outsourcing costly digital spending via cloud computing and telework). The intangible nature of many digital technologies can also lead to "scale without mass" effects (Brynjolfsson et al., 2008[23]), allowing firms, such as online platforms, to become global players with a relatively small number of employees and few physical assets. ${ }^{1}$ Over the past decade, online platforms have indeed become ubiquitous and many of them expanded globally (Costa et al., forthcoming[24]).

10. A leading explanation of the failure of digital technologies to offset the aggregate productivity slowdown lies in their complementarity with intangible assets that are often difficult and costly to acquire. These include organisational capital and management skills, human capital and ICT-related skills as well as data and software, in addition to access to communication infrastructure. For instance, a recent OECD study finds that by closing half of the skills gap with top performing countries the average OECD country could increase the adoption rate of digital technologies by $6-8 \%$ and raise firm productivity growth by 3.5 percentage points after three years (Sorbe et al., 2019 $9_{[25]}$ ). Historically, complementary factors were crucial to the widespread deployment and effective use of other major general purpose technologies (Box 1). Looking ahead, new technologies requiring complex skills and altering the way people think, act and interact among each other and with machines, such as artificial intelligence, are likely to strengthen the complementarity between digital technologies and intangibles (Sorbe et al., 2019 [25]; Brynjolfsson, Rock and Syverson, 2018[26]).

11. Acquiring these complementary intangible assets, however, is costly and takes time, which could explain the delay of the digital transformation in generating strong aggregate productivity growth

\footnotetext{
${ }^{1}$ For instance, the Whatsapp messaging platform went from serving 200 million users with 50 employees at the beginning of 2013 to serving 420 million users with 55 employees just one year later (Olson, 2015[223]).
} 
(Brynjolfsson, Rock and Syverson, 2018[26]). Moreover, the ability to acquire these assets greatly differs across countries, firms and individuals, implying rising digital divides across and within countries. For instance, emerging-market economies have markedly lower intangible assets than advanced ones (Figure 3).

\section{Figure 3. Intangible assets vary markedly across countries}

Gross fixed capital formation of intangible assets over value added (2011-2015 average)

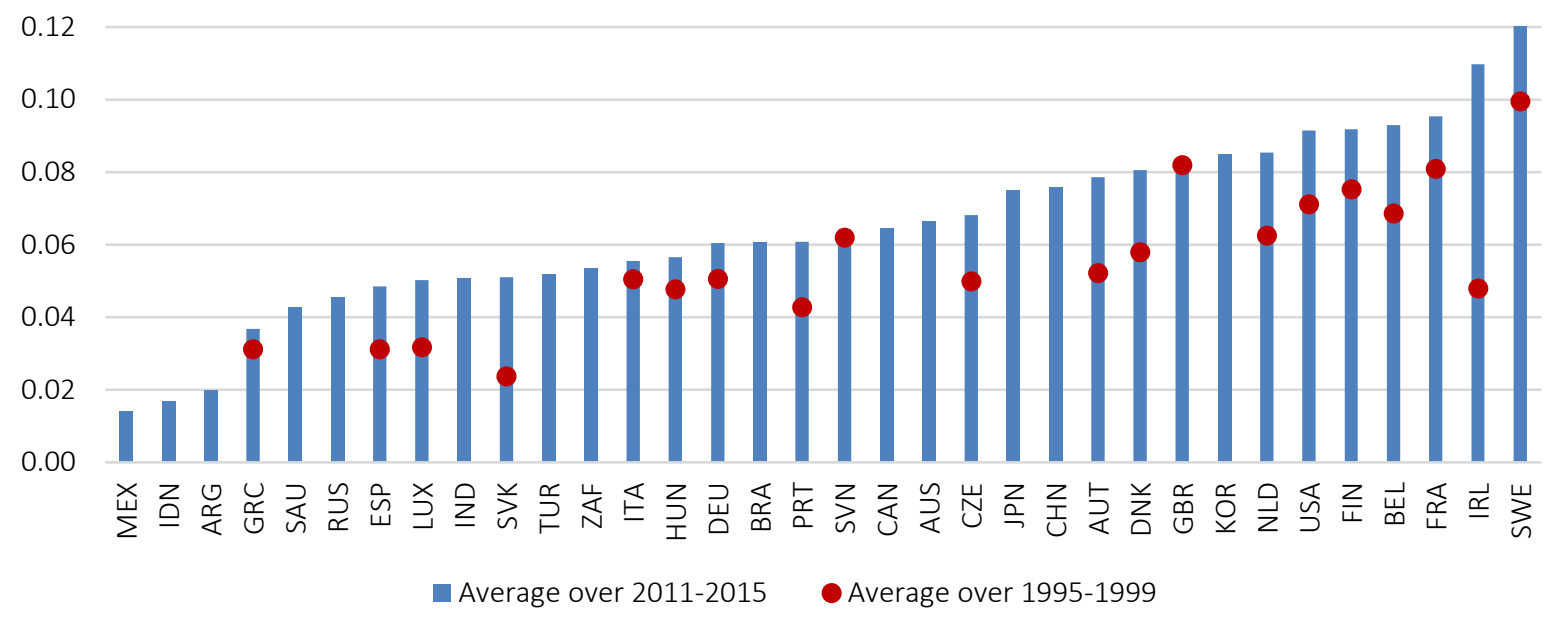

Note: Intangible assets' gross fixed capital formation is computed either using INTANInvest or, for countries not covered by INTAN-Invest, using a combination of data sources and a novel methodology described in Demmou and Franco (2021 $[10])$. In order to make the two sources fully comparable, the training component of intangible investment is excluded. Value added is based on the World Bank GVA data series. Total gross fixed capital formation is obtained from the OECD National Accounts (GFCF by assets tables), complemented with data from National Statistical offices and corrected to account for the intangible asset types that are not included in standard GFCF calculations. All the three variables employed to build the ratios of interest are measured in national currency constant 2015 prices.

Source: Demmou and Franco $\left(2021_{[10]}\right)$.

12. Digital divides also persist in terms of internet connectivity. Still today, less than half of the South African and Indian population have private access to internet services, against two thirds of the population in several advanced economies. The world average broadband penetration is just half of the OECD average (OECD, 2020[5]). Although average broadband speed has generally been increasing over time (OECD, 2020[27]), access to high-speed internet connections remains limited and continues to vary greatly across countries (Figure 4). In 2020, the percentage of fibre in total fixed broadband connections was about $80 \%$ in Korea and Japan against less than $5 \%$ in Germany, Austria, United Kingdom, Israel, Belgium and Greece.

\section{Box 1. Innovations and productivity growth: the long view}

History shows that the relationship between technological innovations and productivity growth is neither simple nor linear. Labour productivity growth has followed decade-long waves, with accelerations following not major inventions or innovations but rather their widespread diffusion. Many general purpose technologies have generated productivity gains only after a long temporal lag and might even have contributed towards a productivity slowdown in the early adoption phase (David, 1990[28]; Hornstein and Krusell, 1996[29]; Brynjolfsson, Rock and Syverson, 2018[26]). For instance, it took a full century of complementary innovations and improvements for the steam engine (developed in the late $18^{\text {th }}$ century in Great Britain) to be widely adopted and yield broad based productivity benefits (Allen, 2012[30]; Rosenberg, 1972[31]). The diffusion process of the electrical dynamo across production plants was also slow as it started 20 years after the introduction of the carbon filament incandescent lamp by Edison and Swann (in 1879), and of the central 
generating stations in New York and London (early 1880s) (David, 1990[28]), and was greatly heterogeneous across countries and industries (Ristuccia and Solomou, 2014[32]). Data on the diffusion across countries of major new technologies over the past 200 years indicate that differences in adoption lags and in the intensity of use explain a significant share of the cross-country income divergence in the $18^{\text {th }}$ and $19^{\text {th }}$ centuries (Comin and Mestieri, 2018[33]).

Implementation lags and differences in intensity of use can also help explain the missing productivity benefits of advanced digital technologies. As with other general-purpose technologies of the past, the widespread and effective use of digital technologies follows an extended period of incremental technical improvements, a gradual and protracted diffusion process and the confluence with other streams of technological innovations, through which they can acquire a broad domain of specific applications. The productivity effects of advanced digital technologies thus hinges on complementary innovations and investments involving organizational changes, new skills and the accumulation of intangible capital (Brynjolfsson, Rock and Syverson, 2018[26]; Pilat and Criscuolo, 2018[34]).

The level of skills can explain the speed and timing of technology diffusion (Rosenberg, 1972[31]; Broadberry and O' Rourke, 2010 $[35])$. Secondary inventions improved and adapted major new technologies, facilitating their diffusion and allowing them to better suit demand (Rosenberg, 1972[31]). The diffusion hinges on the skills necessary to make and utilise inventions in their operating environment.

Access to finance also played an important role. The diffusion of innovation is characterised by two stylised facts: 1) high uncertainty about the benefits; 2 ) high sunk costs of new technologies (Hall, $\left.2009_{[36]}\right)$. For this reason, in some countries advanced financial systems have played an important role in overcoming these two barriers (Cameron, 1975[37]). In Belgium, France, and Germany, for instance, joint stock investment was organised to promote railway equipment and construction based on imported British steam engine technology, and it facilitated the rapid diffusion of steam engines in these countries.

National and international policy support and coordination is another factor that can facilitate not only the creation but also the diffusion of new technology:

- Based on numerous case studies, mostly from the United States, Mazzucato $\left(2015_{[38]}\right)$ argues that public investments have proved transformative in many industries, such as the Internet, nanotechnology, biotechnology and clean energy, and helped to create new markets. Such transformational public investments were the result of policies aimed at tackling what were considered unique challenges and not just at correcting market failures.

- Empirical studies show that in the 1920s the expansion of international trade facilitated the diffusion of electricity technology across countries financed by allowing for the provision of long-term loans for overseas infrastructure investments (Cameron, $1975_{[37]}$ ). After WWI, international capital markets experienced a remarkable recovery with the de facto establishment of the gold-exchange standard as an international monetary system in 1928, and war-debt settlements with the Young Plan in 1929, though trade tariffs remained high (Broadberry and $\mathrm{O}^{\prime}$ Rourke, 2010 ${ }_{[35]}$ ). In the same vein, some studies show that the resurgence of restrictions on capital mobility since the 1930s slowed the diffusion of technology and productivity growth (Wolf, 2010[39]). 
Figure 4. Broadband subscriptions vary in terms of coverage and quality

Fixed broadband subscriptions per 100 inhabitants, by speed tiers, June 2020

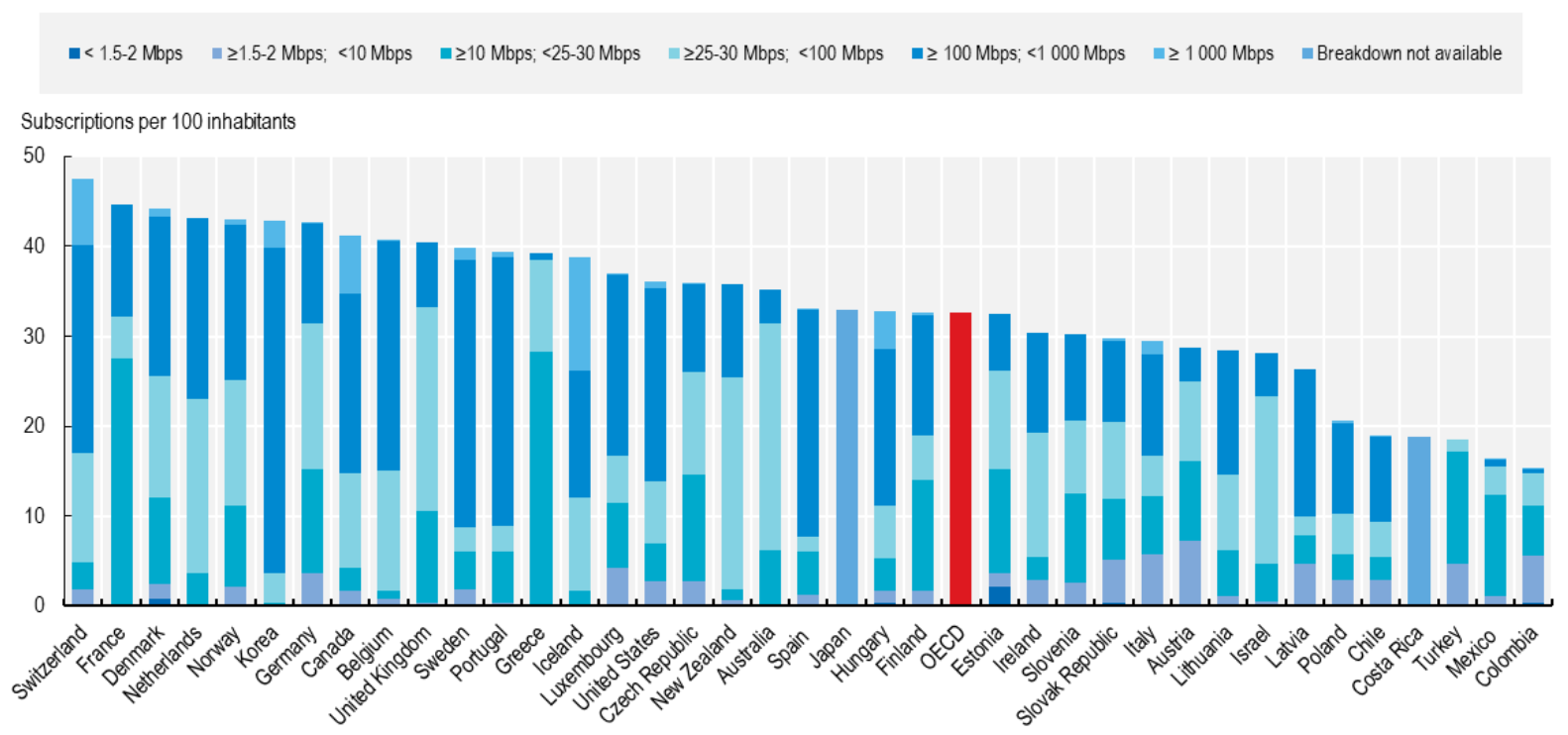

Note: Based on Dec. 2019 speed tiers. Mbps = Megabits per second. Australia: Data reported for December 2018 and onwards is being collected by a new entity using a different methodology. Figures reported from December 2018 comprise a series break and are incomparable with previous data for any broadband measures Australia reports to the OECD. Speed tier data are only for services purchased over the National Broadband Network (NBN), which comprise the majority of fixed broadband services in operation. There is no public data available for the speed of non-NBN services. Mexico and Switzerland: Data are preliminary. New Zealand : Speed tiers are for 2018 instead of 2020. Poland: Data are OECD temporary estimates.

Source: OECD, Broadband Portal, www.oecd.org/st//broadband/oecdbroadbandportal.htm (accessed on 3 June 2020).

13. Within countries, the digital divide between rural and urban areas is wide (Figure 5, Panel A). On average across OECD countries, the region with the best digital infrastructure has a 23 percentage point higher share of people with access to fast (above $30 \mathrm{Mbps}$ ) internet networks than the region with the worst access; one in three households in rural areas do not have access to high-speed broadband at all (OECD, 2020[40]). In Italy, for example, $90 \%$ of urban households benefit from access to high-speed broadband, but only $43 \%$ of rural households do so. Overall, only seven countries, out of 26 for which data are available, have succeeded in providing more than $80 \%$ of households in rural regions with a highspeed connection.

14. Overall, productivity in rural areas is typically $20 \%$ lower than average productivity in urban areas within the same country, with this gap yawning in many countries (OECD, 2019 $9_{[41]}$. COVID-19 may have contributed to widening geographical divides as urban areas have better digital connectivity and a larger share of jobs amenable to telework than rural areas (OECD, 2020[42]) (OECD, 2019[41]). Policies to address infrastructure bottlenecks (both in terms of availability and affordability) in places with insufficient access can therefore entail a double-dividend by improving productivity and attracting high value-added jobs to rural areas.

15. Yet, digital divides can have many more aspects. For instance, in OECD countries internet-use rates are on average $22 \%$ higher for high-income than low-income households. Within households, internet use rates are up to 18 percentage point higher for men than women (OECD, 2019[43]). These differences are likely to be even more marked in developing countries. The gap in internet use between large and small firms also remains significant in some OECD countries (Figure 5, Panel B) and many emergingmarket economies. Moreover, in 2018 less than $20 \%$ of small businesses against $50 \%$ of large firms in OECD countries had access to high-speed broadband (OECD, 2020[5] ). 
Figure 5. Connectivity differs substantially between rural and urban areas and firms of different sizes

Panel A: Percentage of households with access to Internet $>30 \mathrm{Mbps}$ in 2019 or latest available year, at the rural and national levels

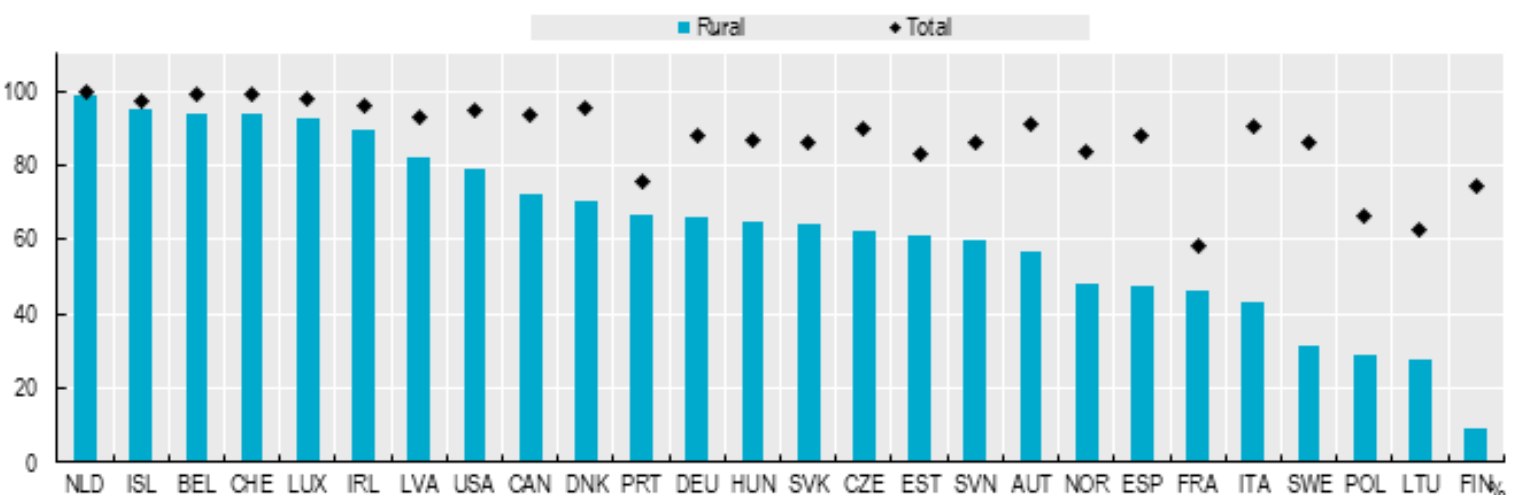

Panel B: Broadband connectivity by size, as a percentage of enterprises in each employment size class, 2020 or latest available year

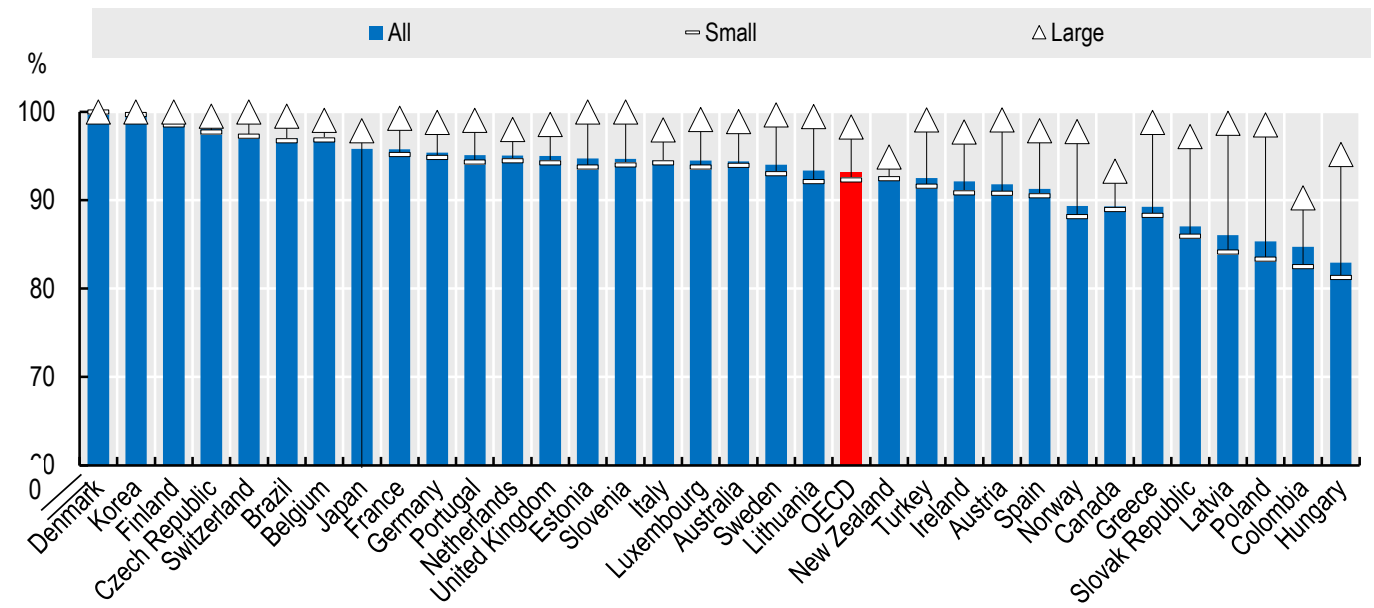

Note: Except where otherwise stated, only enterprises with ten or more employees in manufacturing and non-financial market services industries are considered. Size classes are defined as: small (10-49 employees), medium (50-249 employees) and large (250 employees or more). Fixed broadband only except Canada, Japan, Korea and Switzerland, which include mobile broadband.

Source: Panel A: OECD (2020[40]); OECD 2020; Panel B: OECD ICT Access and Usage by Businesses Database, http://oe.cd/bus (accessed in May 2021).

\subsection{Productivity gaps between frontier and laggard firms are increasing}

16. The uneven diffusion of digital technologies is a key determinant of the productivity gap between frontier and laggard firms. Firm-level data indicate that for firms at the technological frontier productivity growth has continued at an unbroken pace while it has decelerated for low productive firms (Figure 6, Panel A) (Andrews, Criscuolo and Gal, 2016[44]). These gaps have sizeable macroeconomic consequences as lifting the productivity of the lowest productive firms (i.e. firms in the bottom $40 \%$ of the productivity distribution) to median productivity level would boost aggregate output by up to $6 \%$ (Berlingieri et al., 2020[45]).

17. The productivity gap has widened especially in digital-intensive sectors (Figure 6, Panel B) suggesting that the muted effect of digitalisation on aggregate productivity reflects the inability of laggards to adopt the best practices and technologies from the frontier (Gal et al., 2019[46]]). Similarly, Corrado et al. 
(2021 forthcoming $\left.{ }_{[47]}\right)$ find the productivity difference between frontier and laggard firms to be significantly larger in intangible-intensive sectors (Figure 6, Panel C).

Figure 6. The productivity gap between frontier and laggard firms is increasing

Panel A: Evolution of multifactor productivity in the non-farm, non-financial business sector

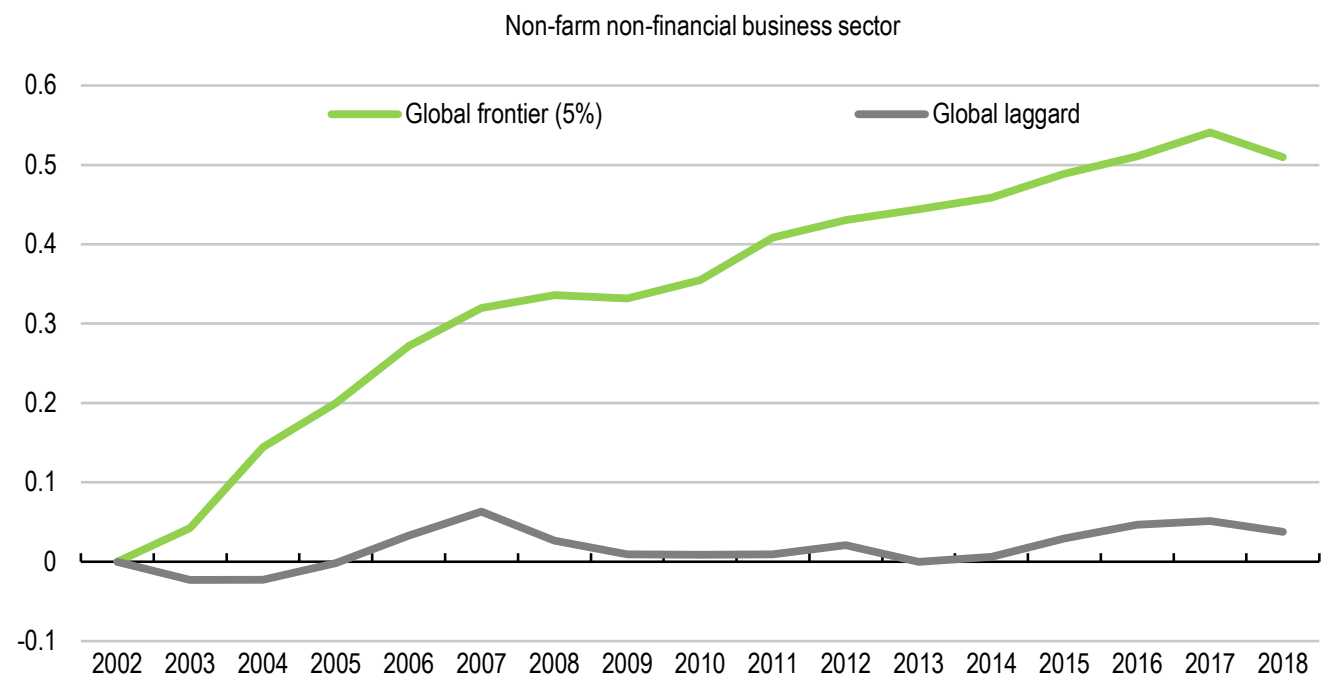

Panel B: Evolution of productivity dispersion (difference between frontier and laggards) grouped by digital intensity, $(2002=100)$

\section{Productivity dispersion by digital intensity}

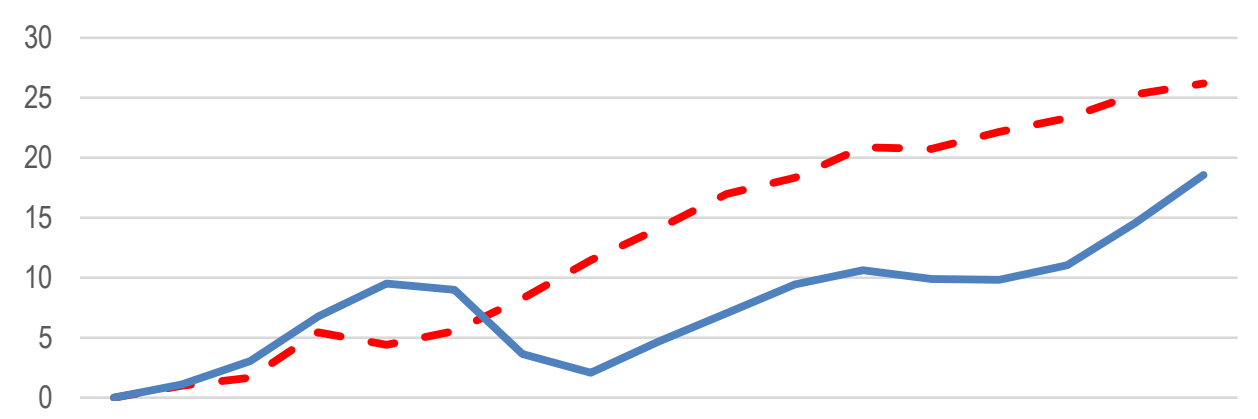

20022003200420052006200720082009201020112012201320142015201620172018

- High digital intensity industries

Low digital intensity industries 
Panel C: Evolution of productivity dispersion (difference between frontier and laggards) grouped by intangible intensity $(2000=100)$

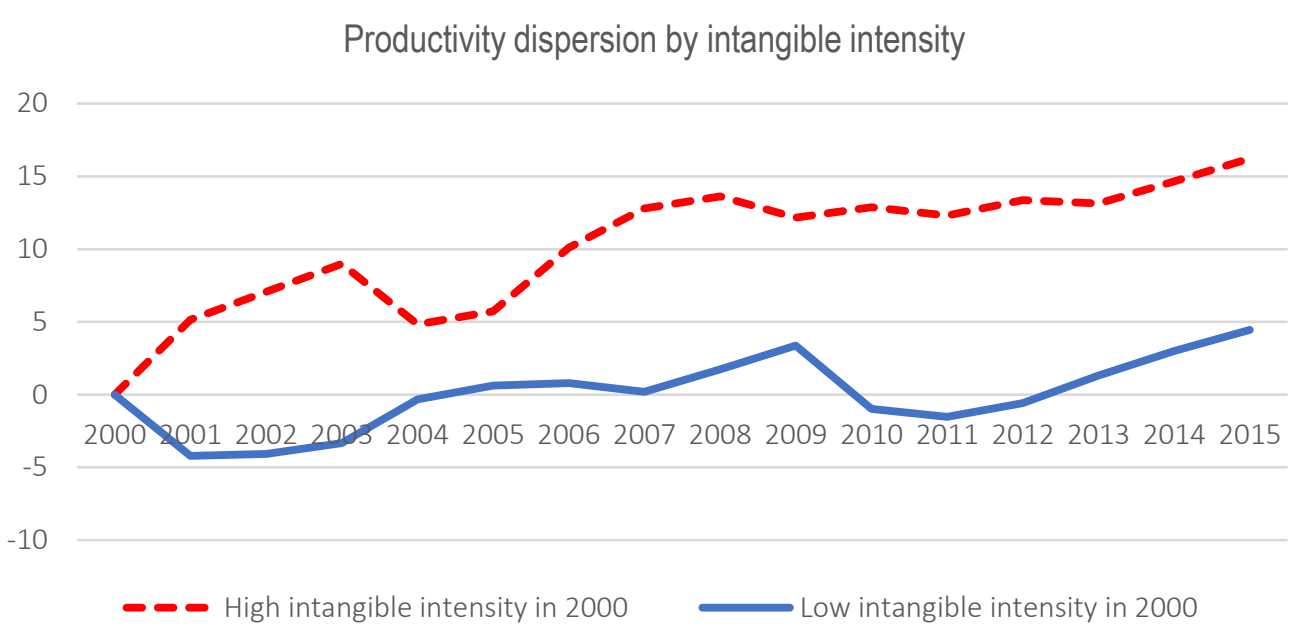

Note: Panel A and: B: The "frontier" is measured by the average of log multi-factor productivity, based on the Wooldridge (2009) methodology, for the top $5 \%$ of companies with the highest 3-year moving-average productivity levels in each 2-digit industry and year, across 22 OECD countries. The "firms below the frontier" corresponds to the average of the log-productivity distribution of non-frontier firms in each industry and year. The values obtained for the detailed 2-digit industries are averaged to industry groups that are classified either as having "high" or "low" digital intensities according to the methodology in Calvino et al. (2018). The series are normalised to 100 in the starting year (2002=100). The coverage of companies in the last year, 2018 is more limited than in previous years, hence the figures for that year might be less accurate. Countries that are included in the global frontier calculations in Panel A are: Australia, Austria, Belgium, Denmark, Estonia, Finland, France, Germany, Hungary, Ireland, Italy, Japan, Korea, Netherlands, Portugal, Poland, Spain, Slovenia, Sweden, United Kingdom and the United States. Panel B includes the European subset of these countries. Panel C: The graph plots the evolution of productivity dispersion for high and low intangible intensive industries, after controlling for other factors driving productivity dispersion including average gross output, capital and labour inputs and capital-labour ratios. Country-industries are ranked by their intensity of intangible investment in the year 2000. Countryindustries above the median are classified as "High intangibles intensity", country-industries below the median as "Low intangibles intensity". Averages weighted by gross output across two-digit industries are shown for both groups, normalized to 0 in the starting year. The time period is 2000-15. Productivity dispersion is measured as the $90-10$ difference in multi-factor productivity a la Woolridge, i.e. the difference in productivity between firms at the 90th percentile of the productivity distribution in a country-industry and firms at the 10th percentile. The vertical axes represent log-point differences from the starting year: for instance, productivity dispersion in the high intangible intensity group has increased by about 0.17 in the final year, which corresponds to approximately $17 \%$ higher productivity dispersion in 2015 compared to 2000 . Countries included are AUT, BEL, DEU, DNK, FIN, FRA, IRL, ITA, NLD and PRT.

Source: Panel A and B: OECD based on Bureau van Dijk ORBIS data. Panel C: Corrado et al. (2021 forthcoming $\left.{ }_{[47]}\right)$.

18. As highlighted above, the inability of many firms to adopt and use effectively digital technologies is partly attributable to the lack of complementary intangible assets such as skills (Corrado et al., 2021 forthcoming[47]; Haskel and Westlake, 2018[48]; OECD, 2013[49]). Businesses with access to a large pool of skills or offering formal training courses thus tend to experience higher growth, are more productive and more resilient to economic shocks (Cette et al., 2020[50]; Squicciarini and Samek, forthcoming $[51]$ ). Even among the global top 500 MNEs covered by the OECD Analytical Database on Individual Multinationals and Affiliates (ADIMA), highly digitalised firms recorded in the two years before COVID-19 higher sales growth (after controlling for average industry growth) than less digitalised ones (Figure 7). Recent OECD evidence also show that firms at the productivity frontier employ twice as much high-skilled staff as those that lag behind, pointing to their relative advantage in hiring scarce talents (Figure 8). 
Figure 7. Digitalisation is associated with higher sales growth

Average sales growth

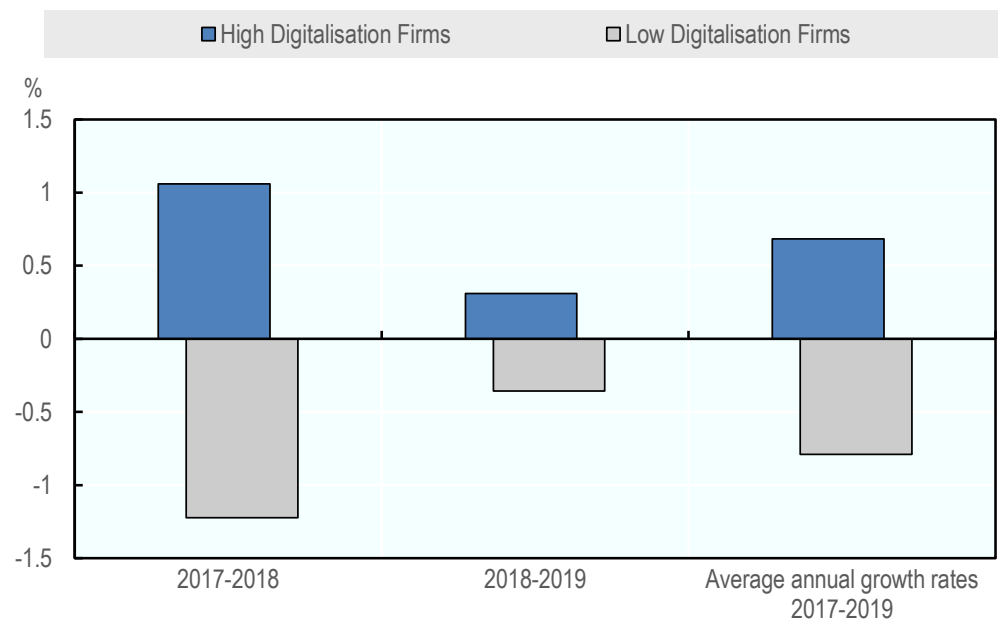

Note: The graphs show the average of normalised sales growth of firms in the OECD ADIMA dataset with a high or low digital presence. For each firm, the normalised sales growth is computed as the firm's sales growth minus the sales growth of the industry they belong to. The digital presence index is computed with the cumulative page rank for the websites belonging to each MNE derived from the OECD ADIMA Database (oe.cd/ADIMA). High Digitalisation Firms are those with a digital presence index above the industry median, otherwise they are classified as Low Digitalisation Firms.).

Source: OECD calculations based on the OECD ADIMA Database (OECD, 2020[52]) (oe.cd/ADIMA).

19. Skill shortages were increasing before the COVID-19 crisis hit, hardening competition for talent and lowering productivity growth, especially of small and laggard firms (Gal et al., 2019 [46]; Manpower, 2020[53]) (Figure 9). As computing memory and speed, software and algorithms developments are rapidly enlarging the scope of artificial intelligence and machine learning applications, many skills may become outdated. Overall, OECD research suggests that in the early 2010 s' $^{\prime} 14 \%$ of jobs were at high risk of automation, rendering their skills obsolete (Nedelkoska and Quintini, 2018[54]). Digital skills are not immune to the risk of obsolescence as for instance, coding skills tend to become outdated after only a few years. Absent policy action, these trends could heighten already pressing skill shortages and job-skill mismatches across OECD and G20 economies.

Figure 8. The skill composition differs along the productivity distribution

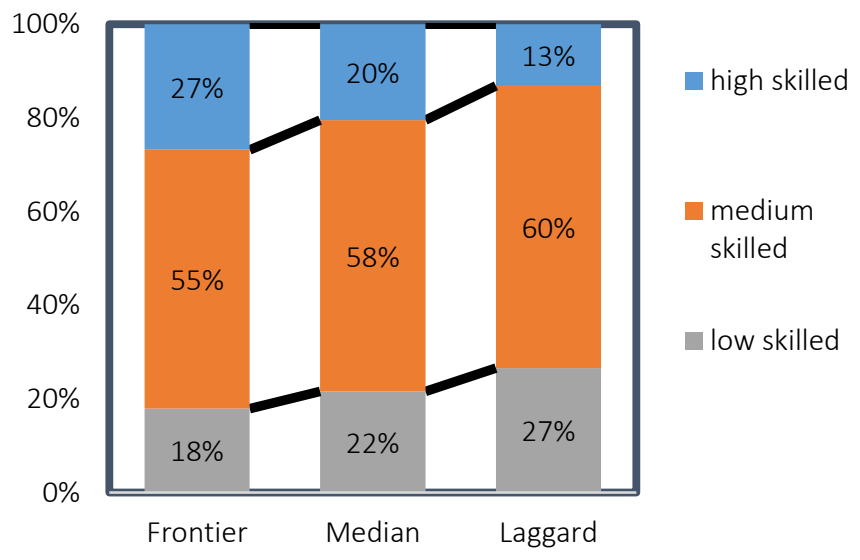

Note: Horizontal axis classifies firms based on labour productivity: Frontier are firms in the $10 \%$ of the labour productivity distribution; Median are those within the $40^{\text {th }}$ and the 60th percentiles; Laggards are those in the bottom $10 \%$

Source: OECD (2021 $\left.{ }_{[55]}\right)$. 


\section{Figure 9. Global skill shortages are high and rising}

Share of companies reporting skill shortages

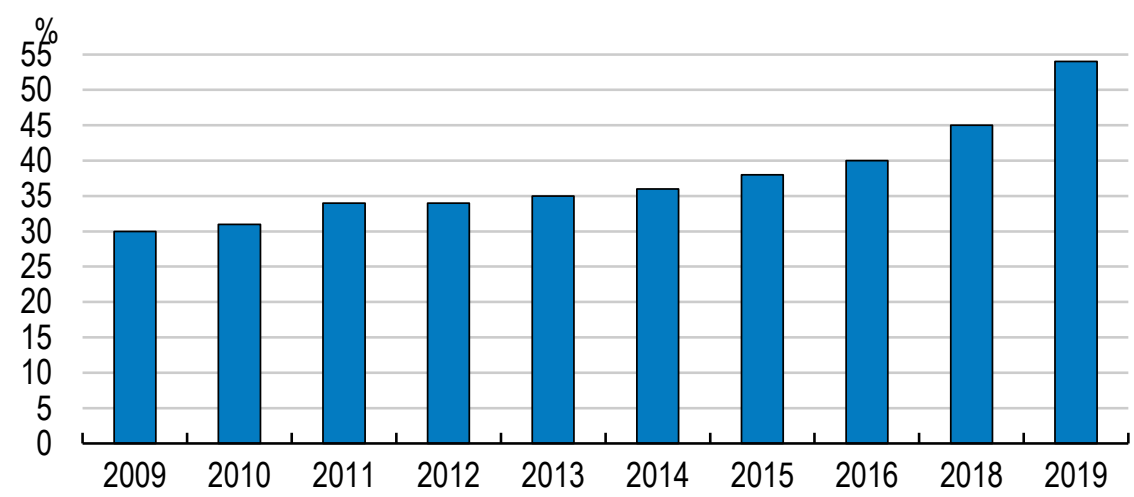

Note: The survey includes the following countries: Australia, Belgium, Finland, France, Germany, Japan, India, Italy, Israel, Mexico, Netherlands, Norway, United Kingdom, United Sates, Spain, Sweden does not cover Russia, Africa (with exception of South Africa), the Middle East, and Indonesia.

Source: Manpower (2020[56]).

20. SMEs generally use digital technologies less intensively than large companies as they face more difficulties in acquiring the necessary complementary factors due to a host of factors, including financial constraints and the absence of professional management (OECD, 2019 $\left.{ }_{[57]}\right)$. This weighs heavily on aggregate productivity performance as SMEs account for the bulk of employment and activity in many OECD and G20 countries (firms with less than 250 employees account for more than $70 \%$ of total employment and value added on average across OECD countries) (OECD, 2019[57]). As a result, the difference between the share of SMEs and large firms adopting digital technologies remains significant, and in some cases (e.g. high-speed broadband and cloud computing) it even increased over the past decade (Figure 10).

Figure 10. Large firms adopt digital technologies more often than small ones

As a percentage of enterprises with ten or more persons employed

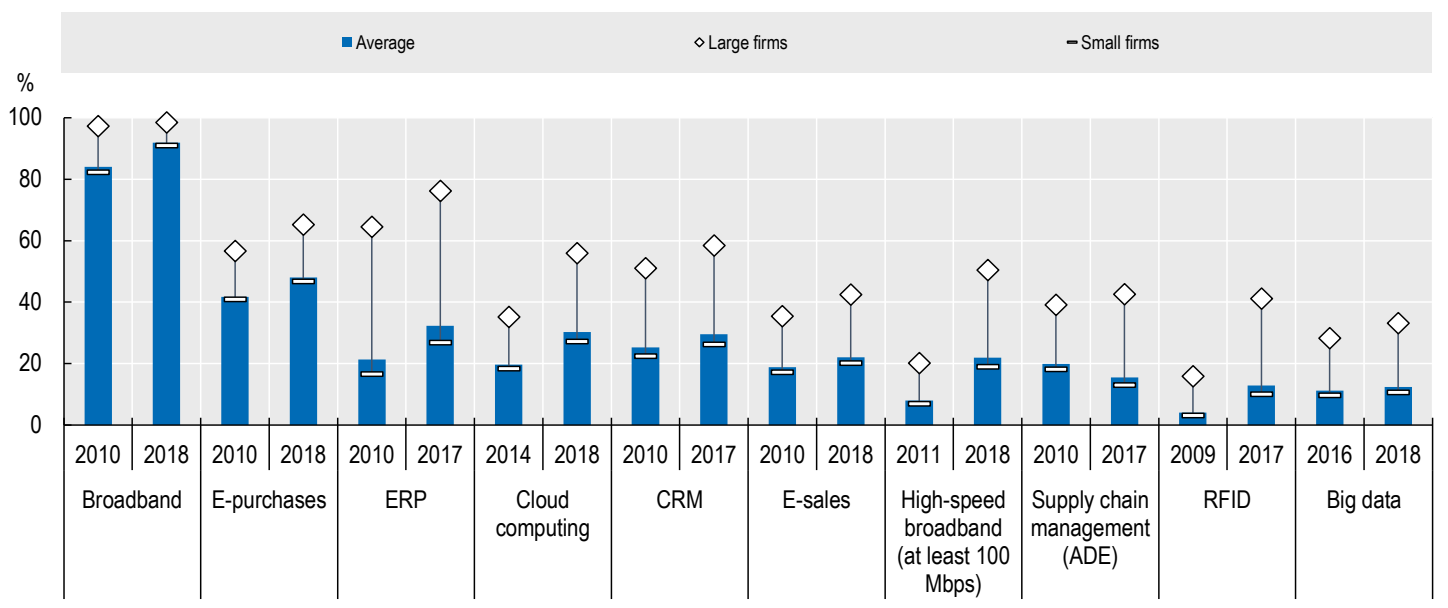

Note: Broadband includes fixed connections with an advertised download rate of at least $256 \mathrm{Mbps}$. For each ICT tool or activity, based on data available for 2010 and 2018, a simple OECD average was calculated for large and small firms. For the most recent year, data refer to 2018 for the majority of countries, with the following exceptions: for ERP, CRM, SCM and RFID, data refer to 2017. For the earlier data year, data refer to 2010 for the majority of countries, with the following exceptions: for cloud computing, data refer to 2014 for the majority of countries. For Big data, data refer to 2016. For RFID, data refer to 2009 for the majority of countries. For high-speed broadband, data refer to 2011 for the majority of countries.

Source: OECD (2019[58]). 
21. Some scholars and policy makers have voiced concerns over the current patent system as it does not always favour investment in intangibles and innovation in addition to slowing down technology diffusion. Patents, along with other intellectual property rights, such as trademarks, designs, and copyright, grant innovators a temporary period of market power to appropriate the benefits for their innovation efforts, thus strengthening incentives to innovate and produce original ideas (Nordhaus, $1969_{[59]}$ ). Patents are less important than other forms of intellectual property rights (OECD, 2015[60]). However, critics argue that the current patent system results in an excessive number of patents, sometimes of dubious quality. The resulting fragmentation of patents' ownership can reduce $R \& D$ and innovation by raising transaction costs, creating bargaining-coordination problems over licensing and exposing firms to excessive patent litigation risks (Cohen, Nelson and Walsh, 2000[61]). These problems can be particularly acute in "complex technology" industries and where innovation is cumulative, as it requires inputs from a large number of patented components held by different entities. When bargaining over patent licensing fails (because of asymmetric information and coordination problems among the many parties involved), follow-on innovation may be forsaken altogether (Heller and Eisenberg, 1998[62]; Bessen and Maskin, 2009[63]; Galasso and Schankerman, 2010[64]).

22. Empirical evidence on the effects of patents on innovation is slowly accumulating. Overall, the body of available evidence suggest that impact of patents on innovation research may be heterogeneous across industries or technologies (Box 2). Changes to patent policy must carefully consider what alternative strategies firms will use to protect their discoveries in the absence of patents. Weakening or abolishing patent rights may push innovators to invest more in research that can be more easily protected through trade secrets and for which reverse engineering and copying is more difficult, thus lowering disclosure (Moser, 2005[65]). Also, weakening patent rights may affect financing opportunities for start-ups and small firms as patents can have an important signalling role in capital markets, making it easier for start-ups and small firms to attract venture capital investors (Conti, Thursby and Thursby, 2013[66]).

\section{Box 2. Recent evidence on the effects of patents on innovation and technology diffusion}

Recent studies cast doubt on the effectiveness of the current patent system in spurring innovation, especially cumulative innovation (i.e. innovation building on previous innovation) (Moser, 2013[67]). Bessen and Maskin (2009[63]) and Bessen and Hunt (2007[68] $)$ show that when innovation is cumulative patent protection stifles innovation. They take as an example the software industry in the United States through the 1980s and 1990s where a series of court decisions strengthened significantly patent protection for computer programs. Firms in industries known to accumulate large patent portfolios for strategic reasons (computers, electrical equipment, and instruments) acquired most of the software patents granted. Not only software development and innovation were quicker before these court decisions but also firms that acquired most of the software patents actually reduced their R\&D spending relative to sales. However, Sampat and Williams $\left(2019_{[69]}\right)$ find that patents on human genes had no quantitatively important effect on follow-on scientific research and product development, suggesting that at least in this sector patents do not seem to hamper follow-on innovation.

Galasso and Shankerman (2015[70] $)$ exploit quasi-experimental variation in court decisions in the United States to invalidate patents to show that court invalidation leads to a $50 \%$ rise, on average, in citations to the focal patent. The positive impact starts only after two years the court decision, which is consistent with the entry of new downstream innovators, and is concentrated in fields characterized by complex technology and high fragmentation of patent ownership (i.e. computers, electronics, and medical instruments). This point to the importance of bargaining-license failure as a factor blocking follow-on innovation. Also, the effect of patent invalidation on follow-on innovation is entirely driven by patents owned by large firms, which increases the number of small innovators subsequently citing the focal patent. 


\subsection{Digital and productivity gaps contribute to income inequality}

23. The growing productivity dispersion has far-reaching implications for inclusive growth as it tends to widen income gaps. In many OECD and G20 countries, differences in average wages across firms explain about half of overall wage inequality, with the remaining half explained by the wage differences among workers in the same firms (Figure 11). In turn, differences in average wages across firms are mostly attributable to firm-level productivity differences, with differences in workforce composition playing a lesser role (Criscuolo et al., 2021 ${ }_{[71]}$ ). This points to a close connection between productivity and wage dispersion, which in turn contributes to income gaps as wage dispersion has been a key driver of rising income inequality over the past decades.

\section{Figure 11. Difference in average wages among firms explain a large share of overall wage inequality}

Dispersion of wages within countries, latest available year.

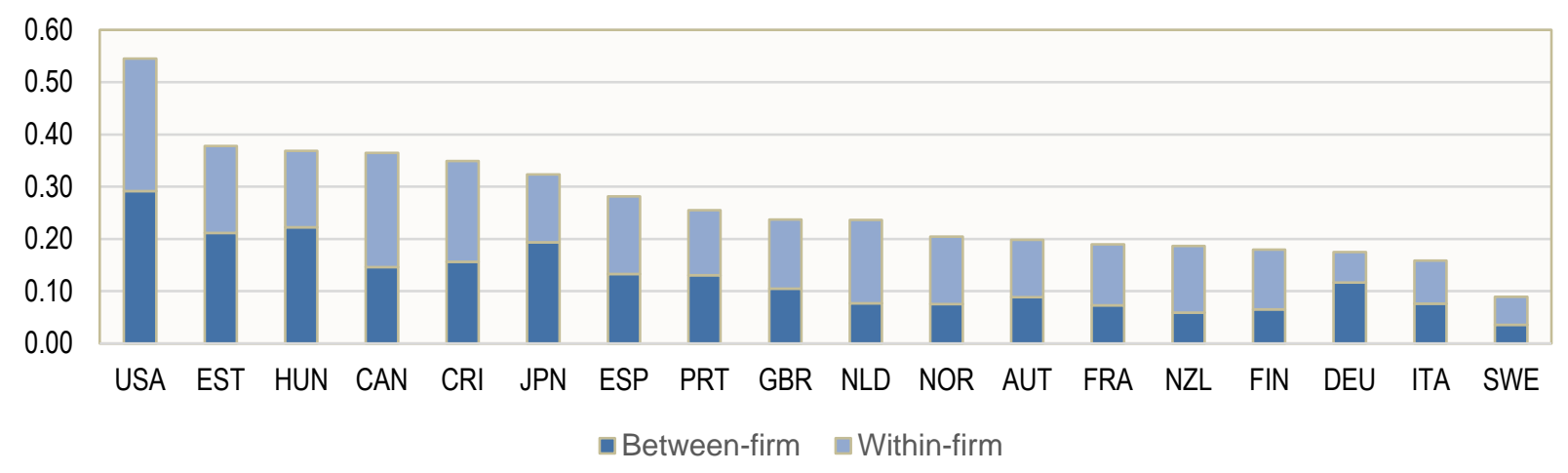

Note: The dispersion in wages within countries is measured with the log wage variance.

Source: Criscuolo et al. (2021 [71]).

24. Closing digital gaps by supporting technology adoption, easing access to intangibles - especially for small and low productive firms - and eliminating skill shortages can boost aggregate growth while reducing productivity and wage dispersion. Of course, other factors affecting the wage-bargaining power of firms and workers come into play as well (Criscuolo et al., 2021 ${ }_{[71]}$ ). For instance, in the presence of firm-level productivity dispersion, barriers to job mobility raise wage inequality by weighing down wages in low-productivity firms and pushing them up in high-productivity firms that need to attract workers. ${ }^{2}$ However, the pass-through of productivity to wages within firms tends to be higher for high-skilled workers, perhaps reflecting the higher firm-specific content of their skills. This indicates that, unless labour market frictions and skill shortages are reduced, high-skilled staff benefit more from digitalisation and higher productivity than low-skilled workers.

\section{Digitalisation, productivity and incomes in COVID times: challenges and opportunities}

25. The COVID-19 shock has plunged the global economy into the deepest recession of peace times (OECD, 2020[72]). The immediate effects of COVID-19 on output and jobs have been large but its longterm impact on productivity dynamics and income inequality is still uncertain as the crisis is still unfolding

\footnotetext{
2 In perfectly-competitive labour markets without frictions, productivity differences between firms would translate into employment rather than wage differences, whereas in frictional labour markets productivity differences are passed on to both employment and wages.
} 
and much will depend on the effectiveness of policies implemented both in the emergency and recovery phases. Evidence suggests that previous epidemics (including SARS, Mers, Ebola and Zika) had significant and persistent negative impacts on labour productivity growth (Figure 12).

26. COVID-19 has generated new opportunities and challenges for closing productivity and income gaps via the digital transformation. On the one hand, COVID-19 provides an unprecedented opportunity to redesign policies in a wide range of areas to increase resilience to shocks, so as to durably accelerate digital adoption in the private and public sectors and share more widely its benefits across all layers of society. On the other hand, there are also reasons why the COVID-19 crisis might lower productivity growth and make closing productivity and income gaps more arduous. This is because of the erosion of human capital, a further deceleration in business dynamism, weaker investment and trade, and the scarring effects the crisis can have on vulnerable groups.

\section{Figure 12. Pandemics lower labour productivity growth}

Effect of past pandemics on productivity

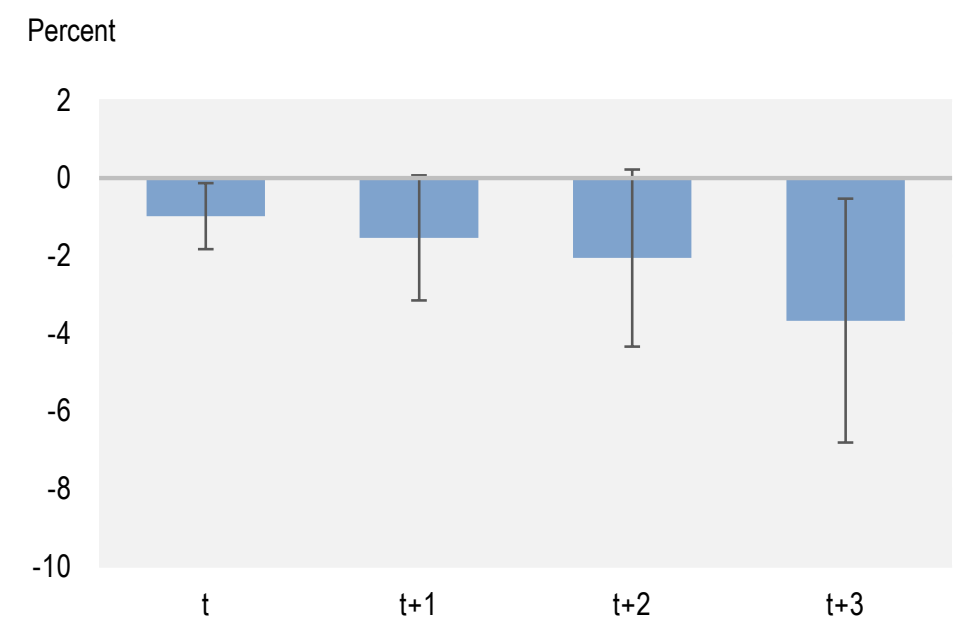

Note: Bars show the estimated impacts of the four most severe biological epidemics on labour productivity, levels relative to non-affected EMDEs (emerging-market and developing economies). The four epidemics considered are SARS (2002-03), MERS (2012), Ebola (2014-15) and Zika (2015-16). Swine flu (2009), which coincided with the 2008-09 global financial crisis, is excluded to limit possible confounding effects. The sample includes 116 economies: 30 advanced economies, and 86 EMDEs. Lines display the range of the estimates with 90 percentile significance. An episode dummy for a specific type of event is 1 if the event occurs at least once (>=1) in a country-year pair and 0 otherwise. Source: Dieppe $(2020[73])$.

\subsection{The COVID-19 shock offers opportunities to revive productivity growth and narrow inequalities}

27. With the right policies, the COVID-19 crisis may herald a sustained and broad-based acceleration of the digital transformation despite the risks looming on the horizon. The benefits from the acceleration in the digital transformation COVID-19 has engendered may outlast the crisis. Moreover, the higher resilience of highly-digitalized and intangible-intensive firms (Figure 13) points to the potential of these firms to drive the post-COVID-19 recovery. Sectors with a higher share of jobs amenable to telework (working-fromhome) also saw a lower decline in job vacancies throughout the first months of the pandemic (Figure 14).

28. However, a sustained and broad-based acceleration of the digital transformation depends on countries' ability to promote the use of digital technologies more widely. Recent OECD evidence suggests that this also hinges on countries' digital preparedness, such as the level of skills and broadband penetration (Costa et al., forthcoming[24]). 
29. The public sector can play an important role in this process by improving the digital provision of information and services to firms and households in addition to developing enabling conditions to promote innovation in service design and delivery, such as digital identity or open government data (OECD, $2020_{[74]}$ ). Digital tools can improve the public sector's efficiency and service quality with positive effects on firm-level productivity growth. For instance, evidence for Italy point to a positive effect of local public-sector efficiency on firms' productivity growth (Fadic, Garda and Pisu, 2019 $\left.{ }_{[75]}\right)$.

\section{Figure 13. Intangible and digital-intensive firms were more resilient to the COVID-shock}

Panel A: Percentage of otherwise viable firms turning Panel B: Change in firm performance high-tech vs non highdistressed after the COVID shock by intangible intensity tech; February-May 2020
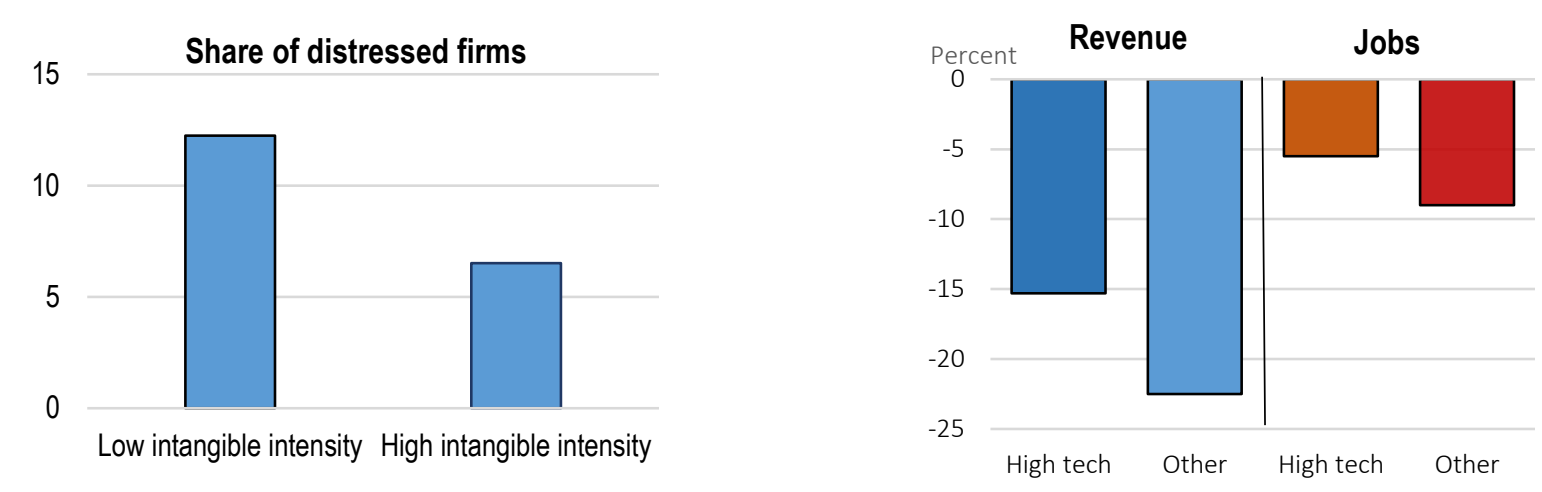

Note: Panel A: The figure shows the percentage of distressed firms by sectoral intangible intensity, where intangible intensity is measured, following (Demmou, Stefanescu and Arquie, $2019_{[76]}$ ), as the median ratio (across firms within industries) of intangible over total assets. Firms are defined as distressed if their book value of equity is predicted to be negative one year after the implementation of confinement measures. Notice that the sample is restricted ex-ante to firms having both positive profits and book value of equity in the 2018 reference year. The underlying scenario foresees a sharp drop in activity lasting two months (the confinement period), followed by a second, relatively smaller, outbreak from the eighth month onwards, accompanied by more limited lockdowns. Panel B: High tech=1 if firm has $5+$ apps connected before the pandemic. Apps pertain to cashflow reporting \& management (Cashflow, Inventory, Square) and E-Commerce (Shopify, Stripe, WooCommerce). Sample includes Australia, New Zealand and Great Britain.

Source: Panel A: OECD $\left(2020_{[16]}\right)$; Panel B: Xero Small Business Insights. 
Figure 14. The decline in job vacancies was lower for firms with a high share of jobs amenable to telework

Average firm level change in job vacancies relative to ability to telework (2019-2020)

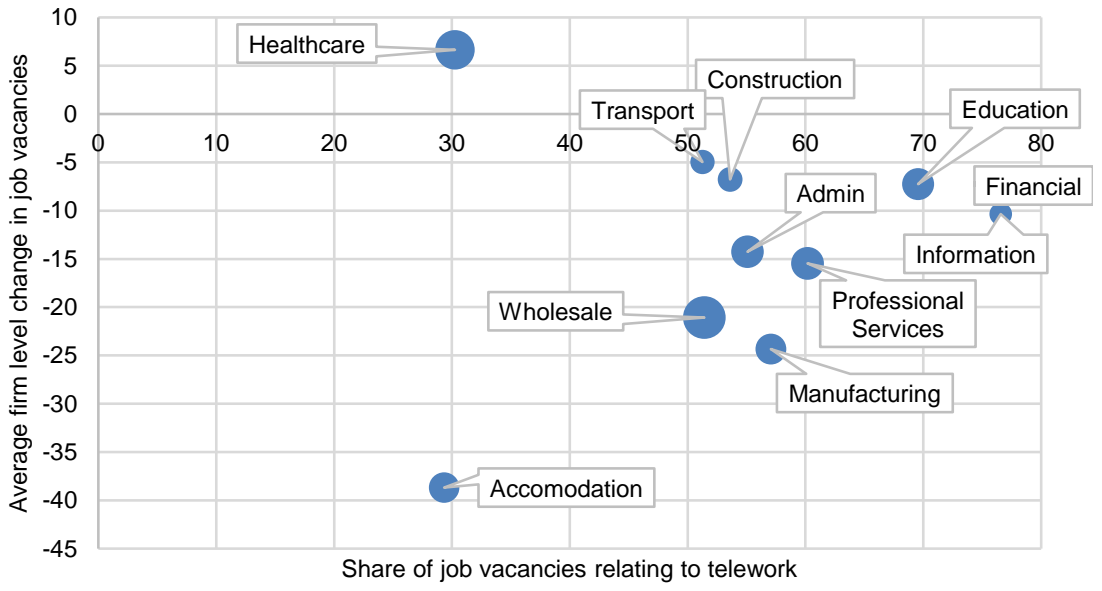

Note: UK based firms with over 100 job advertisements in both 2019 and 2020 are considered for inclusion from the BurningGlass database. Name matching is provided by OpenCorporates and only firms with a sufficient match are considered for inclusion. Companies House data is used for matching firm level data to SIC Industries and firms related to the recruitment industry are excluded as these are subject to bias in the BurningGlass dataset. Non-weighted industry level averages are then presented, with the bubble size reflecting the number of firms considered for each industry.

Source: OECD calculations based on Burning Glass, OpenCorporates and Companies House data.

\subsubsection{COVID-19 has catalysed the digital transformation}

30. Unlike any year before, 2020 was a watershed for the digital transformation (McKinsey, 2020[77]). With physical interactions being impossible or risky, digitalisation became a matter of survival for many firms and organizations, forcing people to adopt new ways of working and abandon entrenched habits. Digitalisation processes that were previously hampered by inertia, lack of vision, urgency, or budget, suddenly became a necessity to maintain business and government operations open.

31. The sudden surge in telework (Figure 15) and cloud computing services (PWC, 2020[78]) epitomises this transformation. Tentative evidence also supports the idea that COVID-19 shifted the direction of innovation towards new technologies supporting working from home (Bloom, Davis and Zhestkova, 2020[79]). In tandem with the general rise of other digital technologies, purchases shifted from brick-and-mortar to online shops, crowning those online platforms offering services free of physical contact, whose use was already increasing in previous years, as winners of this crisis (Figure 16). People and businesses increasingly turned to online platforms to maintain private and professional communications, pursue their education and work, or make online purchases (OECD, 2020[80]). Even among the global top 500 MNEs covered by the OECD ADIMA dataset, since the start of the pandemic, the stock market returns of those with a high digital presence outpaced those with a low digital presence, pointing to market expectations of better performance and profitability associated with the use of digital technologies (Figure 17). 
Figure 15. Levels of telework have skyrocketed

Share of respondents who started to work from home before the pandemic and because of it

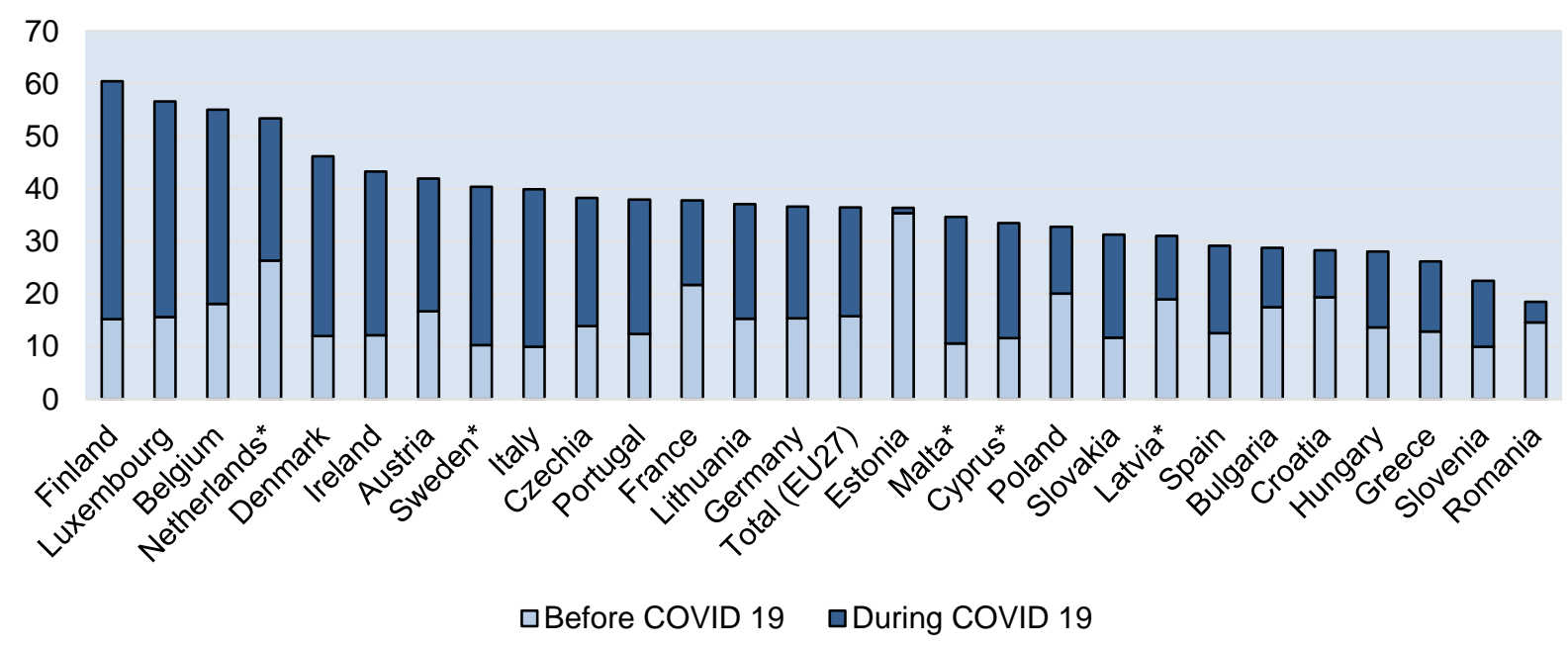

Note: The data show 'no' and 'yes' for respondents in the EU27 when asked: "Have you started to work from home as a result of the COVID-19 situation?" Slovenia is excluded from the data for this question because of a translation issue. * denotes low reliability of data.

Source: Eurofund (2020[81]) http://eurofound.link/covid19data.

\section{Figure 16. Online platform growth before and during COVID}

Panel A: Number of platforms (primary) and platform activity per capita (average 12 countries), 2013-2019;

Panel B: Yearly growth rate of online platform activity

Panel A

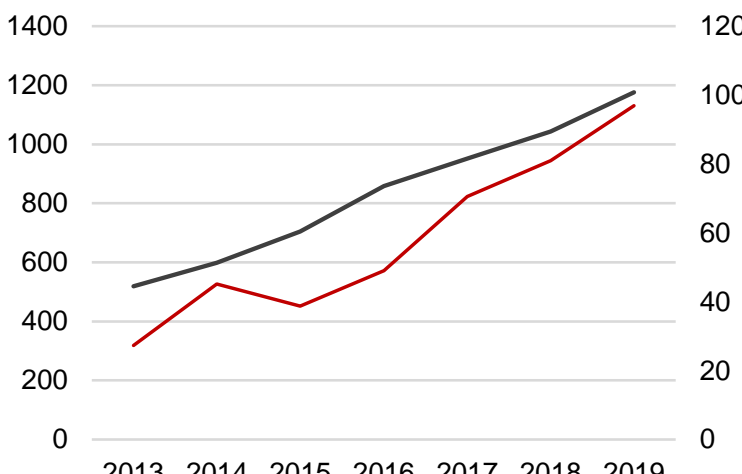

2013201420152016201720182019

Total number of platforms

Average of traffic per capita - 12 G20 countries
Panel B

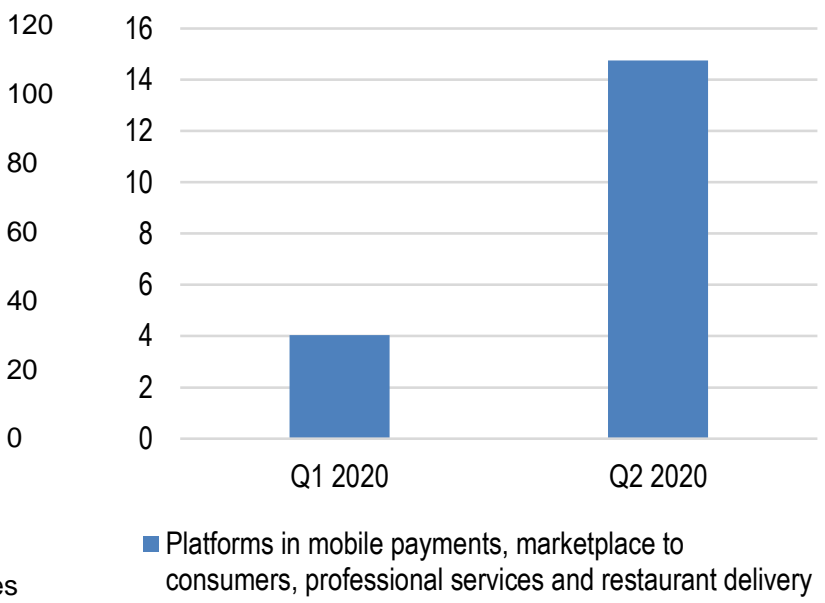

Note: The first graph depicts the total number of platforms in all G20 countries (primary axis) and the average platform activity per capita in 12 G20 countries for which data is available for all years (secondary axis). The second graph depicts the change in the growth of platform search index in the first six months of 2020 relative to the first six months of 2019 Source: Costa et al. (forthcoming[82]). 
Figure 17. Stock market returns surged for firms with a strong digital presence

Stock market return index

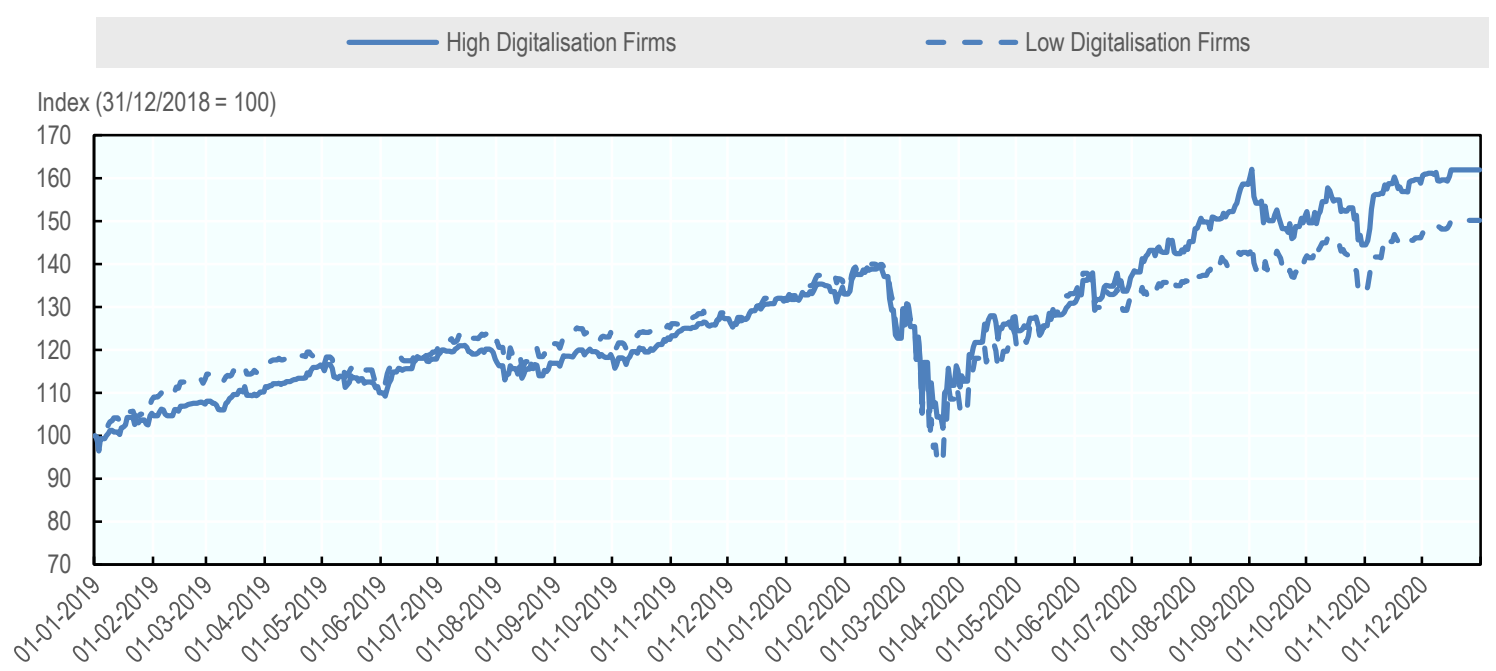

Note: Stock Market Indices allocate each one of the 500 companies within OECD ADIMA to High or Low Digitalisation based on the cumulative Page Rank of the websites identified as belonging to the company within the ADIMA Digital Register whilst controlling for the Economic Sector determined by The Refinitiv Business Classification (TRBC). Allocations are chosen to ensure that the most digitalised $50 \%$ of Market Capitalisation is classified within the "High Digitalisation" Index.

Source: OECD calculations based on (OECD, 2020[52]).

32. The surge in digital adoption could be especially beneficial to SMEs. For instance, online platforms offer simple pathways to digitalisation for firms, while providing services (e.g. outsourcing of data storage, advanced low-cost logistics and payment services, tailored advertising, better communications between buyers and suppliers and dispute resolutions) that can be especially beneficial to micro enterprises and SMEs (OECD, 2021 $[83])$. In line with this idea, preliminary empirical evidence suggests that the productivity benefits from digital platform diffusion are larger for SMEs, suggesting that platforms can play a role in closing productivity gaps between SMEs and larger and more productive firms that are already at an advanced stage of digitalisation (Costa et al., forthcoming[82]).

33. At the same time, recent surveys covering business owners and managers show that the use of digital technologies in small firms has increased to a much lower extent than for large firms since the start of the pandemic (Figure 18, Panel A, left). Yet, smaller firms equally recognize the importance of digital technologies for their business (Figure 18, Panel A, right). Digging deeper, it appears that smaller firms are often restrained by the cost of purchasing digital technologies and a lack of awareness and adequate skills (Figure 18, Panel B), while larger firms mainly face difficulties integrating the digital technologies purchased into their processes.

34. This pattern is consistent with other studies, though the specific impediments micro and SMEs face to digitalise vary across countries. For instance for France, surveys show that small retailers, tradespeople and managers of micro and SMEs are sceptical of the benefits digital technologies. For this reason, they allocate scant time and resources to develop digital adoption strategies and to hire the skills needed to implement them (Faquet and Malardé, 2020[84]). In Indonesia and India, instead, access to reliable communication infrastructure remain one of the major obstacles limiting micro and SMEs' use of the internet and digital technologies (McKinsey, 2016[85]; Falentina et al., 2019 [86]; CSIS, 2018[87]; OECD, $\left.2019_{[88]}\right)$. In China, most of micro firms are not aware of the government's policies to support digital adoption and lack of skills (especially programming skills) is an important obstacle to digital adoption 
(OECD, 2019[89]). Targeted policies to support digitalisation of micro enterprises and SMEs can then contribute to narrowing the digitalisation gaps between small and large firms.

\section{Figure 18. SMEs recognize the importance of digitalisation but face critical challenges}

Panel A: Percent of businesses reporting (left panel) or foreseeing changes in the use of digital technologies (right panel), by number of employees

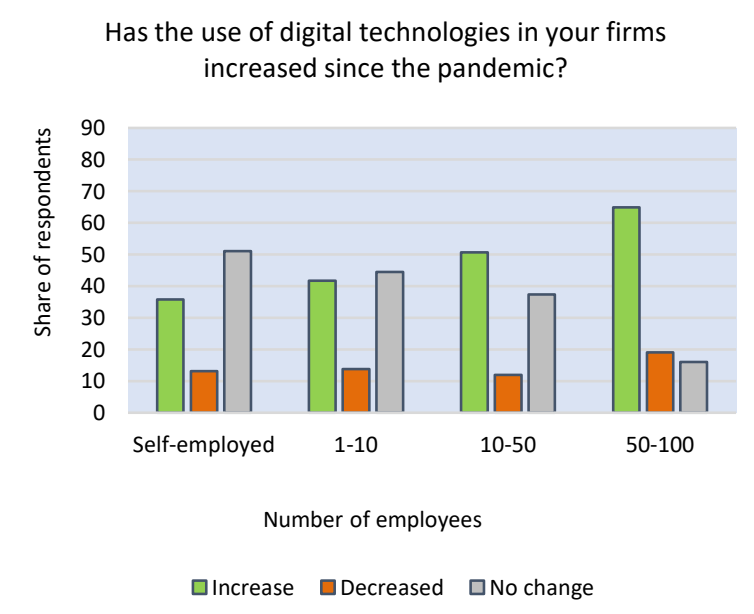
Will COVID permanently change the use of digital technologies in your business?

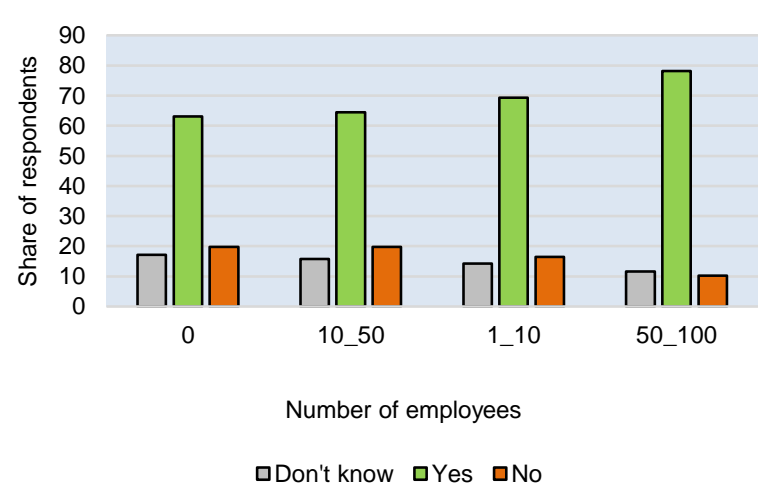

Panel B: Percent of respondents reporting one of the following factors as impediments to digitalisation, by number of employees

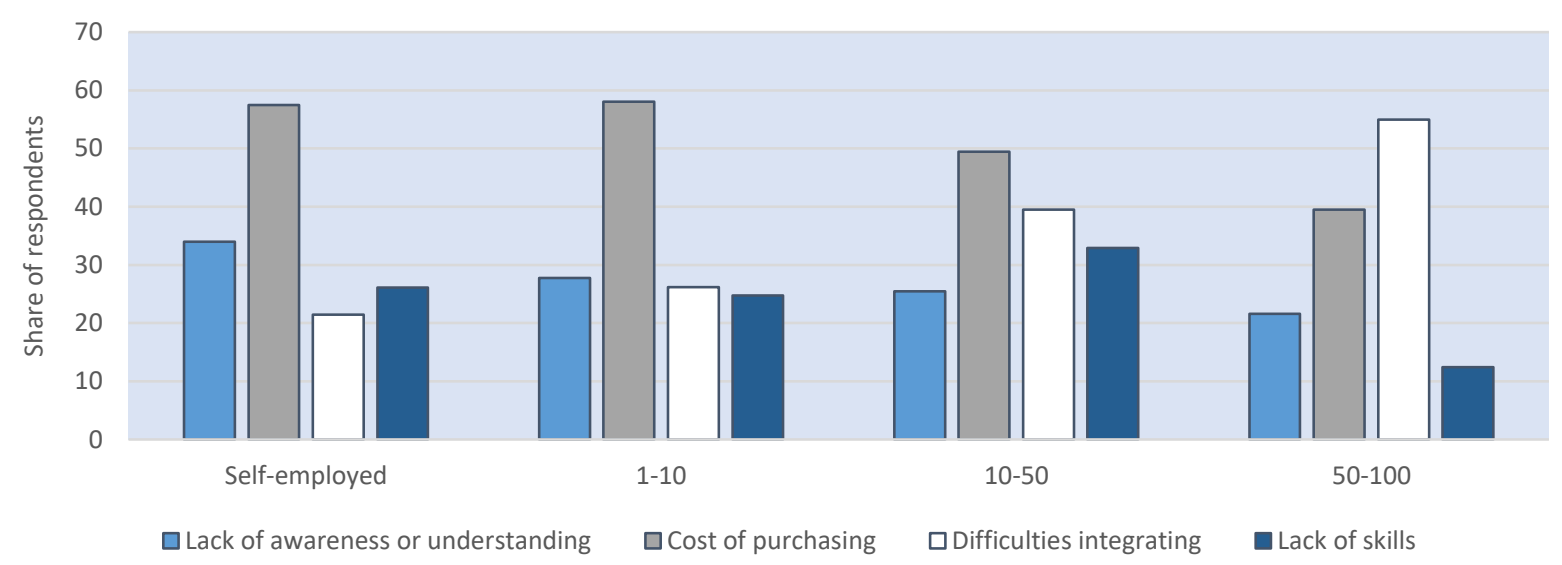

Note: Panel A, left: Share of respondents answering the question "How has this businesses use of digital technologies (left panel) or platforms (right panel) changed since the start of the COVID-19 pandemic?". Panel A, right: "Do you think the COVID-19 crisis is going to change the use of digital technologies permanently for this business?". Panel B: "What are the main obstacles for increasing the use of digital technologies by this business? [Please choose the most important two]." Sample includes weighted data for G20 and OECD countries, excluding China, Latvia and Iceland for which no data was available, with firms up to 100 employees. Only answers respondents that were either owners or managers were taken into account. Respondents that did not reply were dropped.

Source: Facebook-OECD-World Bank - Future of Business Survey (December 2020). 


\subsubsection{COVID-19 can transform the public sector}

35. The crisis put a spotlight on the importance of the public sector's digital preparedness, as this was key to deploying countries' emergency responses and enhancing their resilience. The COVID-19 crisis has imperilled the provision of critical public services through traditional means, pushing countries to shift towards digital service provision to ensure continuity in addition to addressing health and safety concerns (OECD, 2020[90]). The crisis has also raised awareness of the importance of harnessing digital technologies and using data analytics to enhance infrastructure policy and decision-making (OECD, 2020[91]).

36. Beyond the emergency response, the public sector's digital preparedness can be instrumental to closing productivity and income gaps. For instance, if well implemented, digital education can usefully complement traditional education-service delivery and help to tear down geographic and socio-economic barriers, as online teaching material can be tailored more easily to different learning environments and individual needs (López-Gurrero, 2020[92]). Increasing and improving the use of digital tools in education systems has the potential to narrow educational gaps between and within countries, supporting growth and opportunities in lagging areas and enhancing social equity (Bianchi, Lu and Song, 2020[93]).

37. In line with the OECD (2014[94]) Recommendation of the Council on Digital Government Strategies, the crisis has also underlined the importance of investments to support e-government services by enabling firms and individuals to carry out their interactions with governments more easily, more quickly and at lower cost. During the COVID-19 pandemic, governments have also strongly relied on their national portals, social media platforms and dedicated mobile apps to keep citizens informed (UN/DESA, 2020[95]) and to complement existing manual contact tracing through national contact tracing apps (EU, 2020[96]). In addition, open data initiatives on COVID-19 and related indicators were used to promote innovative research and development, and foster trust through transparency and accountability (OPSI, 2020[97]; OECD, 2020[91]). COVID-19 has also encouraged the use of e-procurement platforms and functionalities even when they are not mandatory (OECD, 2020[90]) and of digital tools allowing for the remote access to procurement records for audit purposes (OECD, 2020[90]).

\subsection{COVID-19 poses also new threats to broad-based digital transformation, productivity growth and inclusiveness}

\subsubsection{Lower investment, erosion of human capital, sluggish business dynamics and trade can weigh on the ability of firms to digitalise}

38. The erosion of human capital caused by the disruption of work, school and university education is one of the most important hurdle on the way to broad-based digitalisation and faster productivity growth. The COVID-19 shock is drastically affecting education and training, and depriving workers and job seekers of valuable work experience. For instance, young people entering the labour market during a recession are particularly at risk of experiencing deep and protracted income losses because of lower work experience (Andrews et al., 2020[98]; Oreopoulos, von Wachter and Heisz, 2012[99]). Azevedo et al. $\left(2020_{[100]}\right)$ estimate that a five-month period of school closures could be equivalent to losing more than a half year of schooling and reduce lifetime earnings by $5 \%$ on average. Without compensatory action, lifetime earnings of the current cohort of students could be large also in developed countries, equivalent to about $10 \%$ of GDP in Italy and $13 \%$ in the United States for instance (Gavosto and Romano, 2020 [101]; Psacharopoulos et al., 2020[102]).

39. Leaning and lifetime income losses are likely to be larger for pupils from lower socio-economic background. They often lack basic enabling factors (connectivity, access to devices, quality content, and teacher training, monitoring, school meals and other supports) to cope with school closures (OECD, $2020_{[103]}$; OECD, 2020[104]). In emerging-market economies, children from lower socio-economic backgrounds and girls might also suffer more from the income shock caused by COVID-19 if their families 
put them back to work or the allocation of ICT resources for home schooling favours boys over girls (Azevedo et al., 2020[100]). All this risks enlarging existing educational and digital divides.

40. In many countries, business dynamism was already declining before COVID-19 struck (Calvino, Criscuolo and Verlhac, 2020[105]). This crisis and the policies implemented to mitigate the short-term economic and social effects of COVID-19 could aggravate this trend by further increasing market concentration, dampening the exit of firms and the creation of start-ups:

- Initial evidence suggests that the COVID-19 shock might be contributing to increasing market concentration. Anecdotal evidence indicates that some highly digitalised companies have recorded large increases in sales and activity, reflecting the surge in the demand for digital products and services and the resilience of highly digitalised firms. For instance, activity of many online-platforms in sectors such as retail sales and restaurant delivery has soared during confinement periods (OECD, 2021 $\left.{ }_{[8]}\right)$. These dynamics could intensify winner-take-most dynamics and widen the gap between frontier and laggard firms (di Mauro and Syverson, 2020 [19]; Bajgar et al., 2019 [106]).

- At the same time, some of the necessary emergency responses implemented to mitigate the economic and social damages caused by COVID19 have altered business dynamics on the exit side (Barrero, Bloom and Davis, 2020[107]). These emergency responses (e.g. prohibition of firing of workers, pausing bankruptcy filings, credit guarantees) have succeeded to a large extent in protecting jobs and incomes but they have "frozen" the economy, helping viable and non-viable firms to survive, at least in the short term. Preliminary data for some countries indicates that business mortality has been much lower than what could have been expected from previous recessions. This however could foreshadow a wave of insolvencies in the future as governments lift emergency measures. Many countries' bankruptcy systems are ill-prepared to deal with the potentially large number of business failures, due to ineffective and slow restructuring procedures (OECD, 2020[108] $)$. This could hamper business dynamism in two related ways: 1) widespread liquidation of still viable companies if public support is withdrawn too soon (Demmou et al., 2021 ${ }_{[4]}$ ); 2) the persistence of non-viable "zombie" firms. Both these phenomena risk widening productivity gaps and weighing down on aggregate productivity growth (Adalet McGowan, Andrews and Millot, 2018[109]).

- Business registration data indicate a large fall in business creation in some countries, at least in the early phases of the crisis $\left(\mathrm{OECD}, 2020_{[15]}\right)$. This is worrying as start-ups are often a catalyst for radical innovation, with significant contributions to aggregate productivity and employment growth (Klenow and Li, 2020[110]; OECD, 2020[15]). Compared with the year before, new business registrations in the first half of 2020 were down in Germany, France, Belgium and Iceland, but not in Norway, Japan, Sweden and the Netherlands (OECD, 2021 $\left.{ }_{[111]}\right)$. However, evidence for the United States and France suggests that the initial negative shock of COVID-19 on business creation was short-lived and more than offset by a surge in new business registration in the second half of the year (Dinerlosz et al., 2021 [112]; Gourdon, 2020[113]).

41. The large fall in investment following the COVID-19 shock is an additional risks to aggregate productivity growth, especially if investment cutbacks concentrate in intangible assets that are complementary to digital technologies (OECD, 2020[72]). First, overleveraging of firms during the crisis could depress investment via a debt overhang (Demmou et al., 2021 [4]). Second, protracted and high levels of uncertainty could induce firms to postpone intangible investment, as it is largely irreversible and risky. Third, during the recovery, over-indebted firms may find it particularly difficult to fund intangible investment, as intangible assets are more difficult to pledge as loans' collateral than tangible assets. Finally, the unprecedented drop in economic activity may result in a wave of bankruptcies causing the premature liquidation of many viable intangible-intensive companies (OECD, 2020[15]; OECD, 2021 [114]]).

42. The drop in economic activity caused by COVID-19 has also reverberated through trade and FDI flows, raising concerns about the long-term viability and vulnerability of global value chains (GVCs) (OECD, 
$\left.2020_{[115]}\right)$. However, while GVCs can propagate economic shocks across borders and industries, they also help firms and countries to diversify supply options and contribute to boost innovation, technology diffusion and productivity growth (Halpern, Koren and Szeidl, 2015[116]; OECD, 2013[117]; Gal and Witheridge, 2019[118]).

43. Retreating from GVCs would hamper the international diffusion of new technologies, without necessarily contributing to enhancing economies' resilience to shocks (Bonadio et al., 2020[119]). Weaker GVCs would make it more difficult for SMEs to engage in international markets, lowering knowledge spillovers from multinational enterprises (MNEs), thus widening productivity and digital gaps (López González et al., 2019[120]; Criscuolo and Timmis, 2018[121]).

\subsubsection{COVID-19 risks widening social and economic disparities}

44. As for past pandemics, COVID-19 may contribute to widening income and wealth inequality. Across countries, low-skilled, low-pay and non-standard workers (i.e. informal, self-employed and those in temporary or part-time dependent employment) have experienced starker income and job losses often due to limited opportunities of working from home (Figure 19) (Hupkau et al., 2020[122]; Davis, Ghent and Gregory, 2021 [123]; Galasso and Foucault, 2020[124]). Similarly, women and younger people often saw greater cuts in working hours, being over-represented in the sectors in which only a small share of tasks could be done from home (OECD, 2020[3]; Adams-Prassl et al., 2020[125]).

45. Data for France indicate that households in the upper end of the income distribution experienced a significant increase in financial wealth, reflecting the evolution of asset prices, while the bottom deciles accumulated further debt (Bounie et al., 2020[126]). These dynamics could have inter-generational effects. Children and young people with parents on temporary contracts, for instance, are more likely to drop out of education and be unemployed than children whose parents are on regular contracts (Ruiz-Valenzuela, $\left.2020_{[127]}\right)$. The lower educational attainment of children from disadvantaged background can translate into lower digital skills when adults, thus entrenching digital divides and the corresponding wage gaps.

46. Durable increases in productivity dispersion among firms will also contribute to wage inequality. If the COVID-19 shock negatively affects especially some types of firms - such as low digital and intangibleintensive firms, financially weaker and younger firms, firms operating in traditional sectors - while policies allow them to survive, this could contribute to increasing the share of low productivity firms and widening the productivity gap between frontier and laggard firms. This would lead also to higher wage inequality, in addition to detracting from aggregate productivity growth. 


\section{Figure 19. The magnitude of job losses has been larger for low-skilled workers}

Country-level changes in employment, by skill level, second quarter of 2020 (year-on-year) (percentage)

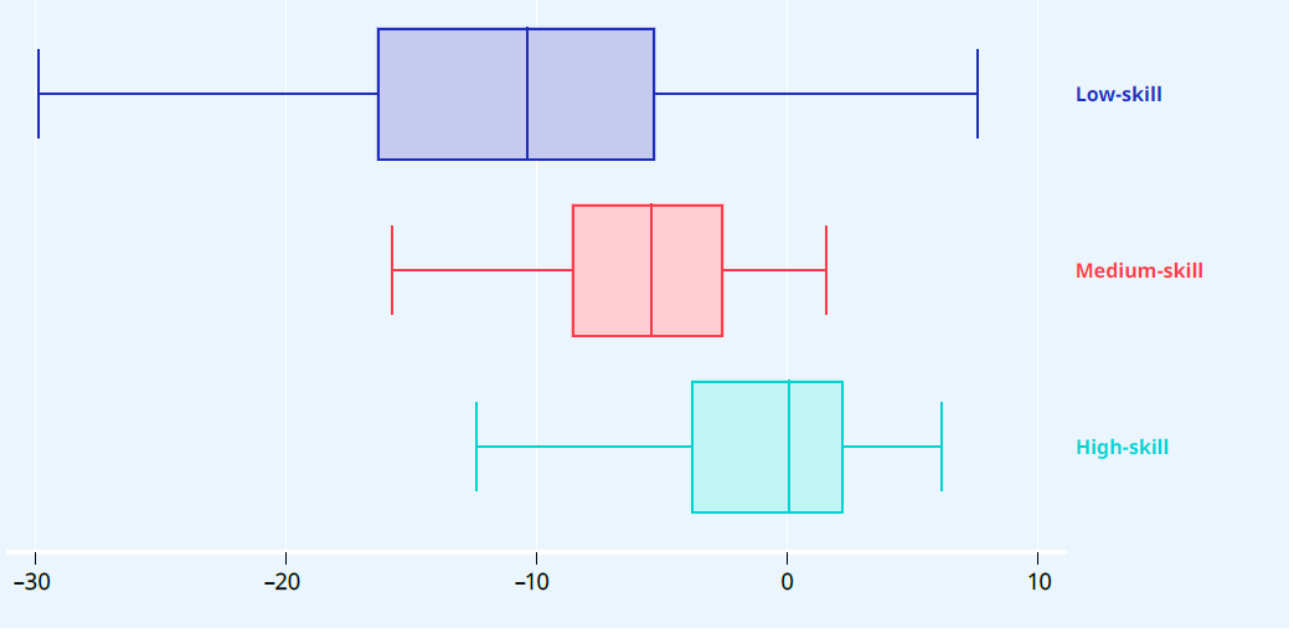

Note: Low-skill = elementary occupations and skilled agricultural, forestry and fishery workers; Medium-skill = clerical support workers, service and sales workers, craft and related trades workers, plant and machine operators, and assemblers; High-skill = managers, professionals and technicians, and associate professionals. The skill levels are based on ISC0-08; see ILOSTAT for further details. The sample consists of 50 high- and middle-income countries and territories with employment data for the second quarter of 2020 disaggregated by occupation. The box graph should be read as follows: (a) the vertical line in the middle of the box represents the median value (50th percentile); (b) the left-hand side of the box (whisker) represents the 25th percentile; (c) the right-hand side of the box (whisker) represents the 75th percentile; (d) the adjacent lines to the left and right of the box represent the lowest and highest values, respectively.

Source: ILO (2021 $[128])$.

\section{The right policy mix can accelerate digitalisation and lower income and productivity gaps}

47. Overcoming the threats while seizing the opportunities from the COVID-19 crisis is only possible with appropriate policies in place. A coordinated and comprehensive policy approach is needed to lift productivity and income in a sustainable and inclusive way. This section singles out the main areas of action in the LIFT approach: Lifelong learning for all; Intangible finance for the knowledge economy; Framework market conditions for the digital economy; Technology access via digital infrastructure.

48. Recent empirical evidence illustrates that progress in these four areas can provide significant productivity gains at the firm-level by accelerating the adoption of digital technologies and encouraging their effective use (Figure 20, Panel A). The strong complementarities between these four policy areas also imply that coordinated policy action can generate significantly larger benefits (Figure 20, Panel B). The breadth of these policy interventions requires an integrated approach to build synergies and manage trade-offs. National and international coordination efforts would help make the most of limited resources, accelerate the international diffusion of best practices and reduce the risk of international regulatory arbitrage. 


\section{Figure 20. A range of policies can support productivity through digital adoption}

Panel A: Effect on firm productivity (through digital adoption) of closing half of the gap with best performing countries in a range of areas. Average OECD country, effect after 3 years.

Panel B: Joint action in several areas can offer additional gains

Effect on MFP after 3 years

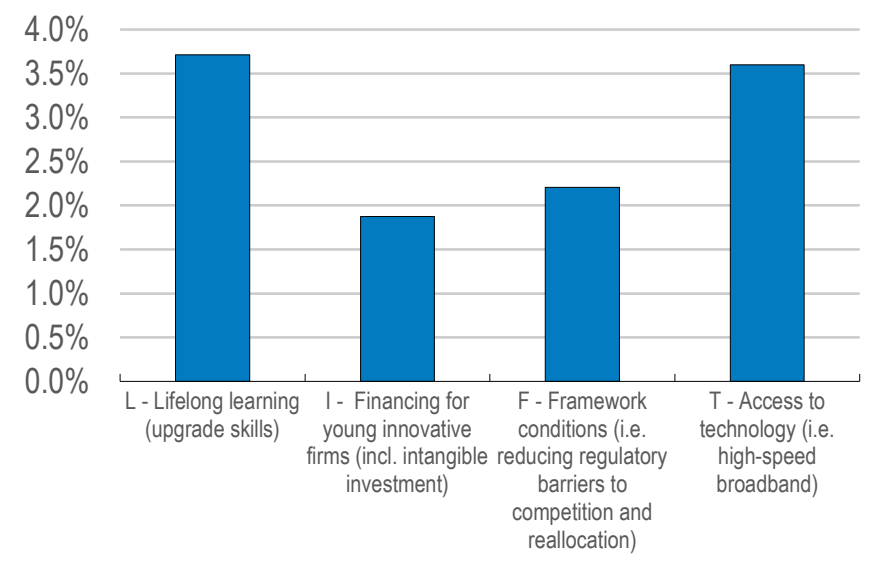

Effect on MFP after 3 years

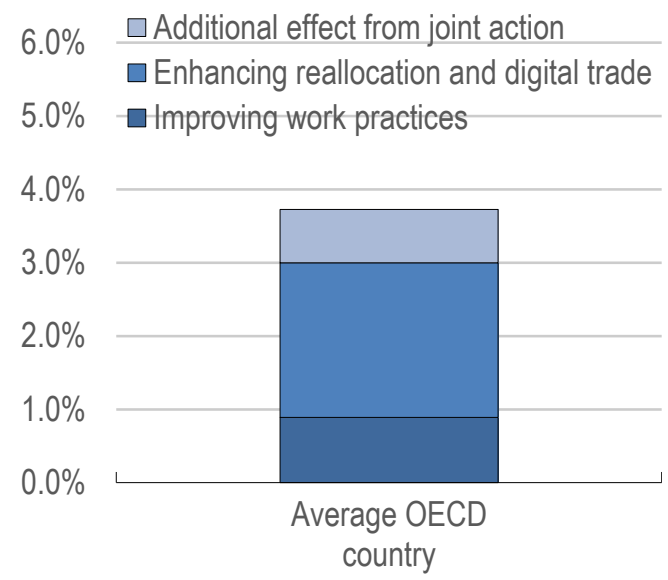

Notes: Panel A shows the estimated effect on multi-factor productivity (MFP) through the adoption of selected digital technologies (Enterprise Resource Planning, Cloud Computing, Customer Relationship Management Software and High-Speed Broadband) of the average firm of policy and structural factors. "Lifelong learning" covers participation in training (for both high- and low-skilled), quality of management schools and adoption of High Performance Work Practices (HPWP). "Financing for young innovative firms" covers the development of venture capital markets and the generosity of R\&D tax subsidies. "Framework conditions" includes lowering administrative barriers to start-ups, relaxing labour protection on regular contracts and enhancing insolvency regimes. "Access to technology" combines the direct effects on productivity and its indirect effects through the adoption of related technologies. "For each of the underlying indicators, it is assumed that half of the gap to the best performing country in the sample is closed. It is also assumed that policy factors in each group are largely independent from each other. Results are presented for the average OECD country. Panel B presents the estimated effect on multi-factor productivity (MFP) of the average firm (through digital adoption) from improving work practices (measured by the prevalence of High Performance Work Practices) and reduced regulation strictness in three areas (employment protection legislation, administrative burdens on start-ups and barriers to digital trade). For each indicator, it is assumed that half of the gap to the country with the best performance/practice in the sample is closed. The dark red bars show the additional productivity gains from joint action in both areas. Results are presented for the average OECD country after three years.

Source: Sorbe et al. $\left(2019_{[25]}\right)$.

\subsection{Lifelong learning for all}

49. In a digitalised world, skills are increasingly important for ensuring that technology adoption provides broadly shared and lasting productivity benefits. The effective use of digital technologies relies on a comprehensive set of skills. They include: (i) generic skills enabling to use of basic digital technologies (e.g. navigate the internet, using emails, using general software); (ii) technical and professional skills (e.g. ICT specialists); and (iii) complementary soft skills, including management, communication or teamwork skills (OECD, 2015[129]; OECD, 2016[130]; Grundke et al., 2017 [1311). The intensive use of digital technologies at work is often associated with tasks that require problem solving ability and more interaction with coworkers and clients (OECD, 2016[132]). For instance the task composition of US workers changed noticeably over the past decades, with non-routine tasks (both analytical and interpersonal ones) becoming more common and manual and routine-cognitive tasks becoming less so (Autor and Price, 2013 [133]) Workers endowed with a combination of several skill categories can reap higher wage premia, especially in digitally intensive industries (Grundke et al., 2018 $[134]$ ). Building strong lifelong learning systems, including both adult learning and high-quality initial education, is critical to providing firms and workers with these key skills (OECD, 2019[135]). 


\subsubsection{Developing inclusive adult learning systems to support digitalisation}

50. Enhancing adult learning opportunities through formal and non-formal channels is crucial to build and upgrade skills over the working life and cope with changing labour market needs. Comparing adult learning systems across countries, however, reveals that many countries still have a long way to go in terms of coverage (Figure 21). The three core areas of policy action to improve coverage and quality include: 1) raising awareness of training programmes and their benefits ; 2) easing financial constraints and; 3) improving quality and ensuring value for money (OECD, 2021 [136]; OECD, 2019 [137]; OECD, $\left.2020_{[138]}\right)$.

\section{Figure 21. Coverage of adult learning systems}

\section{Coverage index (0-1)}

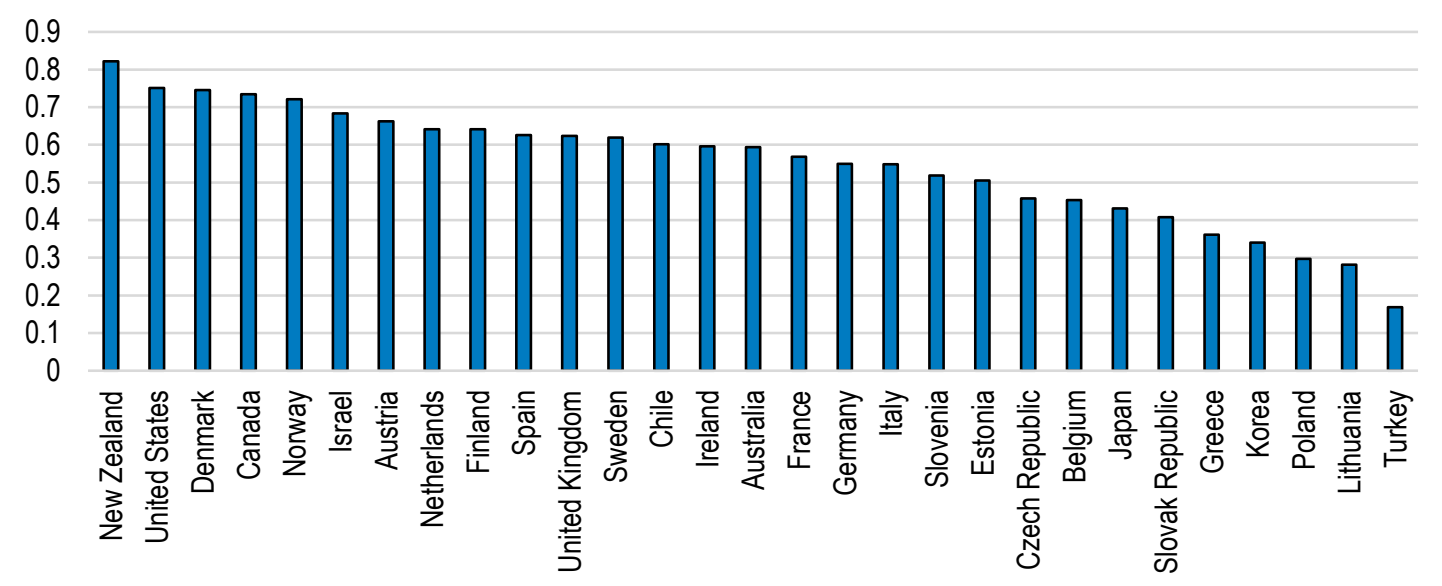

Note: The index ranges between 0-1 (highest coverage) and accounts for the following dimensions: (1) \% of adults who participated in formal or non-formal job-related adult learning in the past 12 months; (2) \% of workers who participate in informal job-related adult learning at least once per week; (3) Median number of hours participants spend on non-formal job-related adult learning per year; (4) 10-year change in the \% of adults participating in non-formal job-related adult learning (\%).

Source: OECD (2019[137]).

\section{Raising awareness of training programmes and their benefits}

51. A prime issue limiting participation in adult learning courses relates to the lack of awareness among many adults, especially those with low or medium skills, of the potential benefits of improving their skills (Windisch, 2015[139]). Indeed, the low-skilled or low-wage earners are significantly less likely to engage in formal and non-formal lifelong learning than other workers (Figure 22). Yet, these workers are likely to bear the brunt of structural changes as digital technologies have a greater impact on the type of tasks of low and medium-skilled occupations than high-skilled ones (OECD, 2019 $[140])$ - a vulnerability that the COVID19 crisis has further highlighted.

52. Targeted awareness campaigns, stressing the value of upskilling could increase the training participation of low and medium skill workers. Japan's National Skills Competition or Korea's Vocational Skill Month go in this direction (OECD, 2019 $\left[{ }_{[137]}\right)$. The returns of these initiatives in terms of firm performance could be significant, as raising the participation of low-skilled people in training has larger positive effects on the use of digital technologies and firms' productivity than raising the participation of high-skilled workers (Figure 23).

53. Reskilling strategies targeting low- and medium-skilled workers would also contribute to reducing educational and wage gaps. Medium-skilled workers were already at higher risk of jobs displacement prior 
to the crisis, as many of these jobs were high-routine occupations that are particularly vulnerable to advances in automation (Nedelkoska and Quintini, 2018[54]). Preliminary evidence also shows a much stronger fall in demand for low- and medium-skilled workers relative to high-skilled ones during the COVID19 shock (Figure 19) (ILO, 2021 [128]). Future technological advances (e.g. artificial intelligence) are likely to weigh even more heavily on the job prospects of low-skilled workers, thus adding to the need of targeted upskilling opportunities for those workers (Brekelmans and Petropoulos, 2020[141]; Squicciarini and Nachtigall, 2021 [142]).

Figure 22. Gap in participation by socio-demographic characteristics

$\%$ of adults participating in formal and non-formal job-related learning
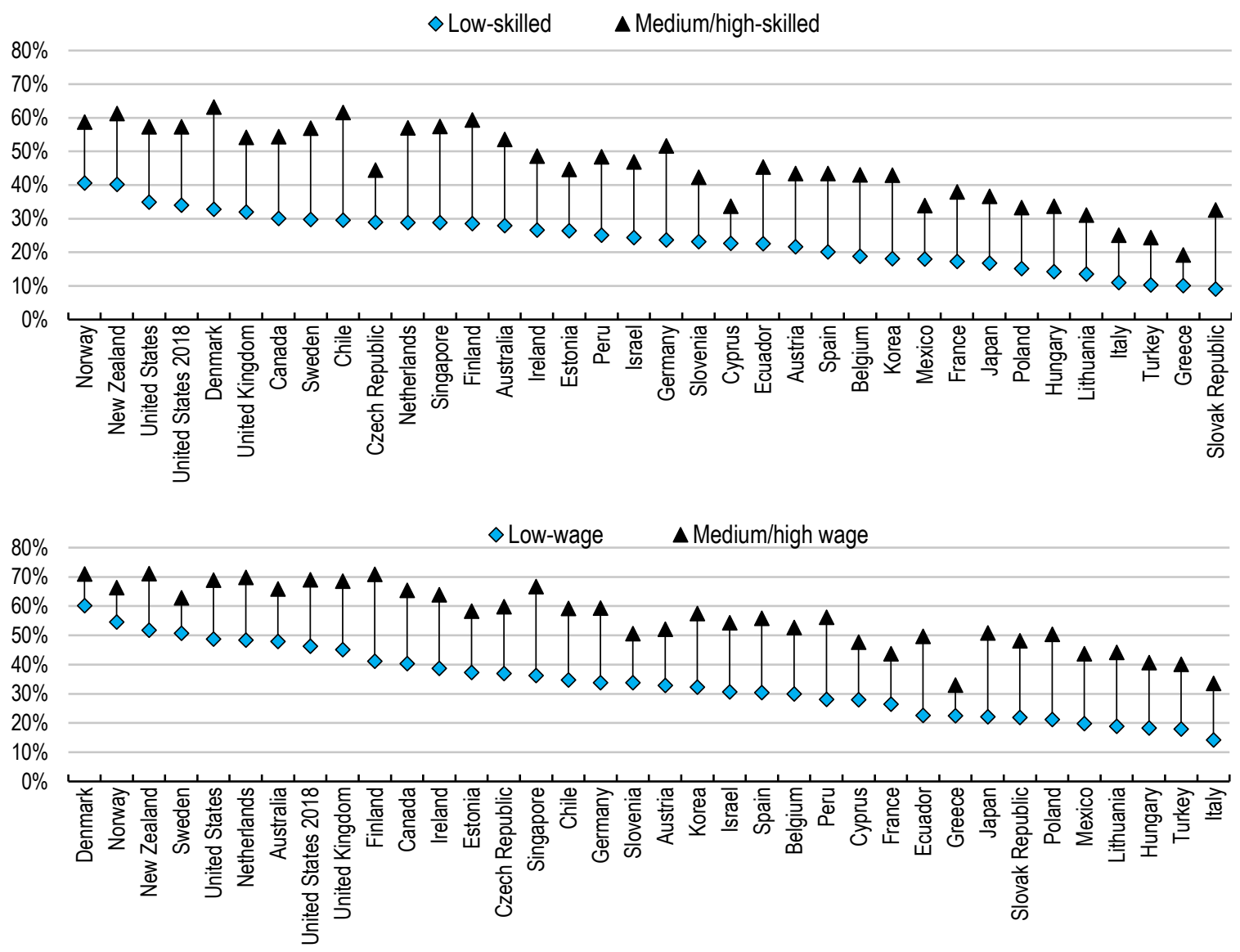

Note: Belgium refers to Flanders only, United Kingdom to England and Northern Ireland; formal and non-formal job-related education and training. Source: OECD $\left(2019_{[137]}\right)$. 


\section{Figure 23. Training the low-skilled contributes strongly to digital diffusion}

Increase in digital adoption associated with training of low and high-skilled workers

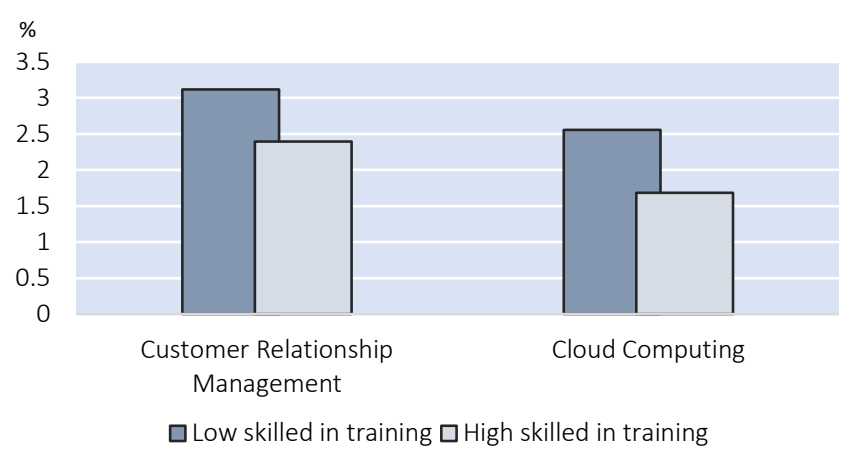

Note: This figure shows the ceteris paribus impact of an increase of a one standard deviation ( $11 \%$ for low-skilled, $13 \%$ for high-skilled) of the percentage of high/low-skilled workers having participated in formal training on the percentage of firms adopting CRM/Cloud Computing technologies between industries with a high or low knowledge intensity based on a sample of 25 European countries.

Source: Nicoletti et al. (2020[143]).

\section{Easing financial constraints}

54. Financial constraints are one of the most important barriers to participation in training along with a lack of time or family constraints, though to different degrees across countries (OECD, $2019_{[137]}$ ). Yet the design of adequate funding mechanisms to support adult learning activities has proved generally challenging. While there is no clear benchmark for the optimal level of spending, adult learning systems are often underfunded (OECD, 2019 ${ }_{[137]}$; UNESCO, 2019 $\left.{ }_{[144]}\right)$ and they receive less funding than other areas of education. Increasing pressures on public finances caused by the pandemic risk further lowering funds for adult training schemes. However, considering that adult learning is an already pressing policy challenge today, and will likely become more important in the future, funds devoted to this area will need to rise.

55. Targeted financial incentives should support the training in transferable skills as private enterprises, especially SMEs, underprovide these because of poaching concerns (Figure 24). SMEs' workers and managers deserve also specific attention as they face tighter financial constraints and fewer resources to provide training than large companies. In a number of OECD and G20 countries, SMEs account for a large share of total employment. Many of these enterprises are family-owned and run businesses with no professional external managers. Unlike large firms, SMEs are also often constrained by the absence of networks to help them identify and access talent (Eurofound, 2017 ${ }_{[145]}$ ). In addition, SME managers' low familiarity with digital technologies may lower the demand for staff with digital skills and for innovation. This along with other factors can contribute to the brain drain and risks setting the country in a low-skill/low productivity trap. Examples of OECD countries introducing, in response to COVID-19, trainings targeting specifically SME managers include Denmark's "SMEs:Digital" strategy and Spain's "Acelera PYME" programme (OECD, 2021 [83]).

56. Policies offering financial support to individual training participants and firms for training programmes vary across countries. In France, for instance, employers receive subsidies to train unemployed workers (Action de Formation Préalable au Recrutement and the Préparation Opérationnelle à l'Emploi) while in Korea, parts of wage costs (on top of training costs) for workers who are on paid training leave are subsidized by the government. Alternatively, incentives can also be set through tax systems, as is done in Argentina, where firms can obtain tax credit rights when workers or job-seekers participate in training, or Italy, which has introduced tax incentives for training staff in advanced digital technologies (through the Industry 4.0 plan) (OECD, 2017[146]). Since 2015, France also grants workers with a personal 
training account (Compte personnel de formation, CPF), which is funded by a compulsory contribution from businesses with more than 10 employees and the unemployment agency. Personal training accounts offer double the amount of training to low-skilled workers compared to high-skilled ones, and this right is retained even if the employer changes or during unemployment spells (Perez and Vourc'h, 2020[147]).

57. In addition to lowering costs, the online delivery of training courses can help to overcome other important obstacles, such as lack of time, hampering participation in training programmes (OECD, $\left.2019_{[137]}\right)$. Online learning allows also training to take place even when the face-to-face interaction becomes limited or impossible due to physical distancing requirements, in addition to cutting some of the costs associated with face-to-face trainings (e.g. renting a room, commuting). The ongoing COVID-19 crisis has already proved an important testing ground for online training and career guidance and anecdotal evidence suggests that many Public Employment Services shifted training offers online. For instance, in the Flemish Region of Belgium, the number of participants in online training provided by the Public Employment Service (VDAB) in the second half of March 2020 was four times higher than in the same period a year earlier (OECD, 2020[148]).

\section{Figure 24. SMEs provide less ICT training for their staff}

Percentage of businesses that use cloud computing services (y-axis) and that provide ICT training to their employees (x-axis) by firm size class, 2018

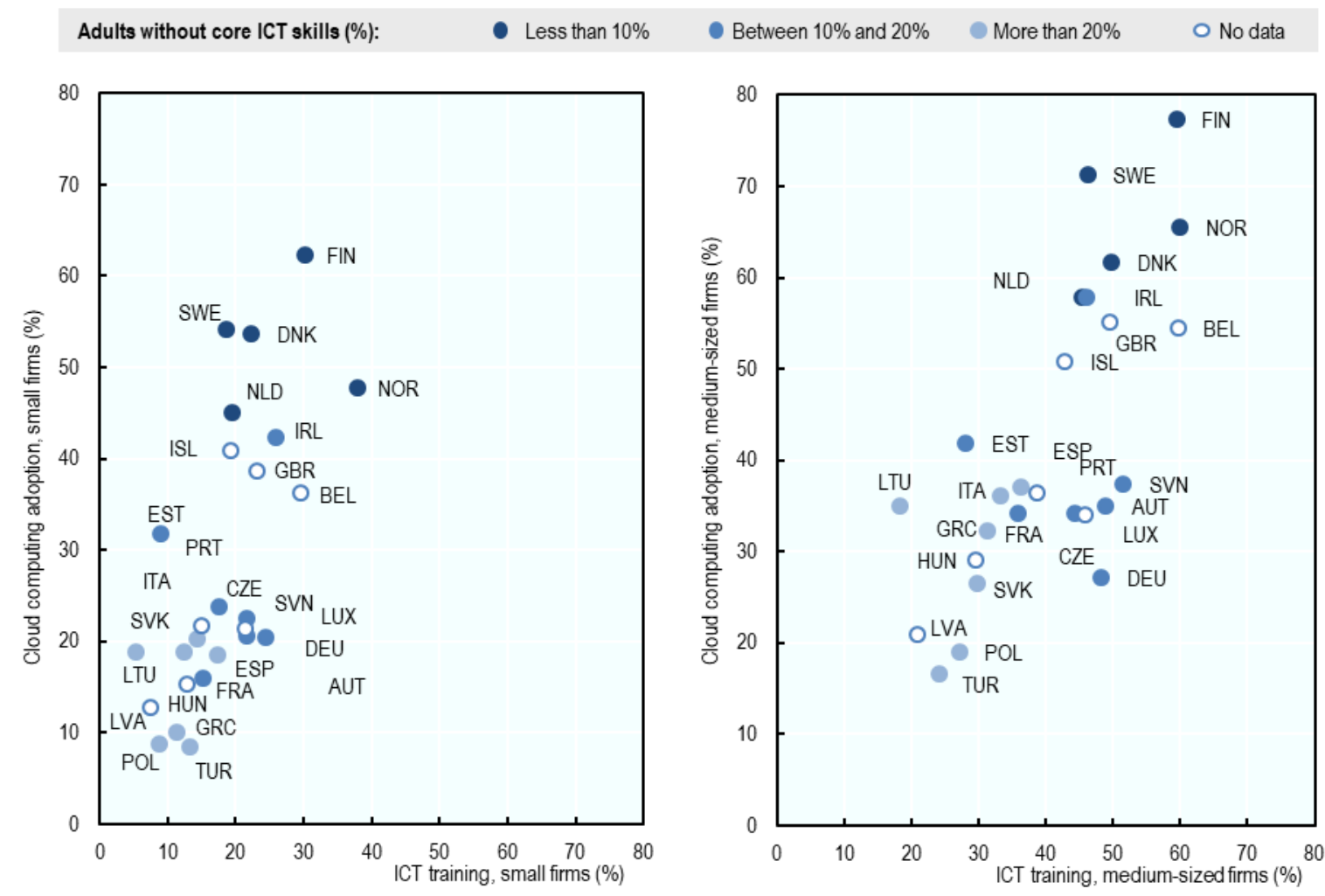

Note: Adults without core ICT skills include 25-65 year old adults with no computer experience or failing the ICT core in the 2015 PIAAC survey. Data on ICT training and cloud computing refer to 2018 or latest year available and comprise businesses with 10 or more employees that respectively provided any type of training to develop the ICT skills of their employees within the last 12 months and that use cloud computing services.

Source: OECD (2019[57]) Statlink http://dx.doi.org/10.1787/888933924799. 


\section{Improving quality and ensuring value for money}

58. More certain and generous sources of funds must be accompanied by quality improvements. Establishing quality standards and performing regular evaluation of adult learning programmes - while maintaining open competition among training providers - are important elements of high-quality adult learning systems. Reliable information on the quality of training programmes help individuals and firms to make informed training decisions and identify opportunities. For instance, recent evidence for the United States shows that well-designed training programs targeting low-wage workers, which include upfront screening processes to make sure participants can take advantage of the skills training, generate substantial and persistent earnings gains (10-40\%) (Katz. et al., 2020[149]). Many countries seek to ensure quality assurance through certification mechanisms and quality labels, or (self)-evaluations. Quality certificates and labels impose minimum requirements that training providers need to fulfil in order to be certified, with the objective of guaranteeing a standard, uniform level of quality of services. In contrast, evaluations - done either by providers themselves or by external bodies - aim at assessing the current quality of training through subjective measures of training satisfaction (OECD, 2021[136]). These mechanisms while potentially useful should not be used as a barrier to entry and to limit competition among training providers.

59. Quality assurance is important, but faces several challenges. Quality labels and certificates, for instance, are costly for providers, both in terms of money and time, and evaluations rely on trust in the providers, especially when results are not published on a regular and comparable basis across providers (OECD, 2021 [136]). On top of this, the number of providers is often extremely large. In France, for example, there are more than 92000 officially registered training providers and many of them are very small (République Française, $\left.2018_{[150]}\right)$. In such atomistic markets, establishing and monitoring quality standards poses difficult practical problems. Furthermore, the trend towards more flexible adult learning provision, for example through e-learning (as highlighted above), adds new challenges to ensure high-quality training (OECD, 2019[137]). Establishing partnerships between public employment services and private-sector training providers and adopting a fee structure that strengthens incentives to provide high quality training may help to reduce monitoring costs and improve training quality. For instance, linking part of the financial incentives or fees training providers receive with the occupational outcomes of training participants (after taking into account individual and regional factors) may go in this direction.

\subsubsection{Raising quality and opportunities in digitalised education systems}

60. In mid-April 2020, 192 countries had closed all schools and universities, affecting almost $90 \%$ of the world's learners (UNESCO, 2020[151]]). Public education systems that were better prepared to shift learning activities online, including through access to essential tools - notably computers or laptops - as well teachers' and students' ability to deal with a virtual learning environment, fared better. The continued need to keep schools closed into 2021, at least in some countries, will further aggravate students' learning losses unless education systems deploy digital technologies in more effective ways and students receive the support they need (OECD, 2020[104]).

61. Many countries were already making efforts to bring a broader array of ICT equipment into their schools and classrooms prior to COVID-19 (OECD, 2020[104]). Data from the OECD's Programme for International Student Assessment (PISA) 2018 for instance show that, between 2009 and 2018, the computer-student ratio increased in 47 out of the 63 countries covered by the PISA survey. As a result, in 2018 there was almost one computer available at school for educational purposes for every 15-year old student and internet connections, though of varying quality, were almost universal in schools that participated in the PISA test. In 2018, the vast majority (89\%) of students also had both a computer and internet connection at home. Shortages of material resources (i.e. school infrastructure and educational materials) remain a problem for socially disadvantaged public schools (in 39 education systems, public schools suffered from more shortages than other schools) and rural schools (in 25 education systems, 
rural schools suffered from more such shortages than other schools) (Schleicher, 2020[152]). On average across OECD countries, both shortages of educational materials, including digital resources, and of physical infrastructure of schools are associated with lower students' performance, although students' socio-economic background explains a large part of the variation in students' performance (Figure 25).

62. Students' universal access to digital technologies is important but does not guarantee equal opportunities and the capacity to build and upgrade digital skills over the lifetime. Differences in traditional academic skills (reading, writing and mathematics) explain to a large extent students' ability to effectively use digital tools for learning (OECD, 2015[153]). Thus, the availability of digital tools is in itself unlikely to boost student learning.

63. If not accompanied by complementary measures, digital technologies thus risk empowering students from stronger socio-economic backgrounds, while leaving those with weak foundations behind (OECD, 2019 $[154])$. Therefore, supporting students in attaining a baseline level of proficiency in reading and mathematics, in addition to expanding access to digital devices and services, will be crucial to create equal opportunities in a digital world.

\section{Figure 25. Socio-economic profiles still largely explain educational outcome gaps}

Change in reading performance associated with various factors

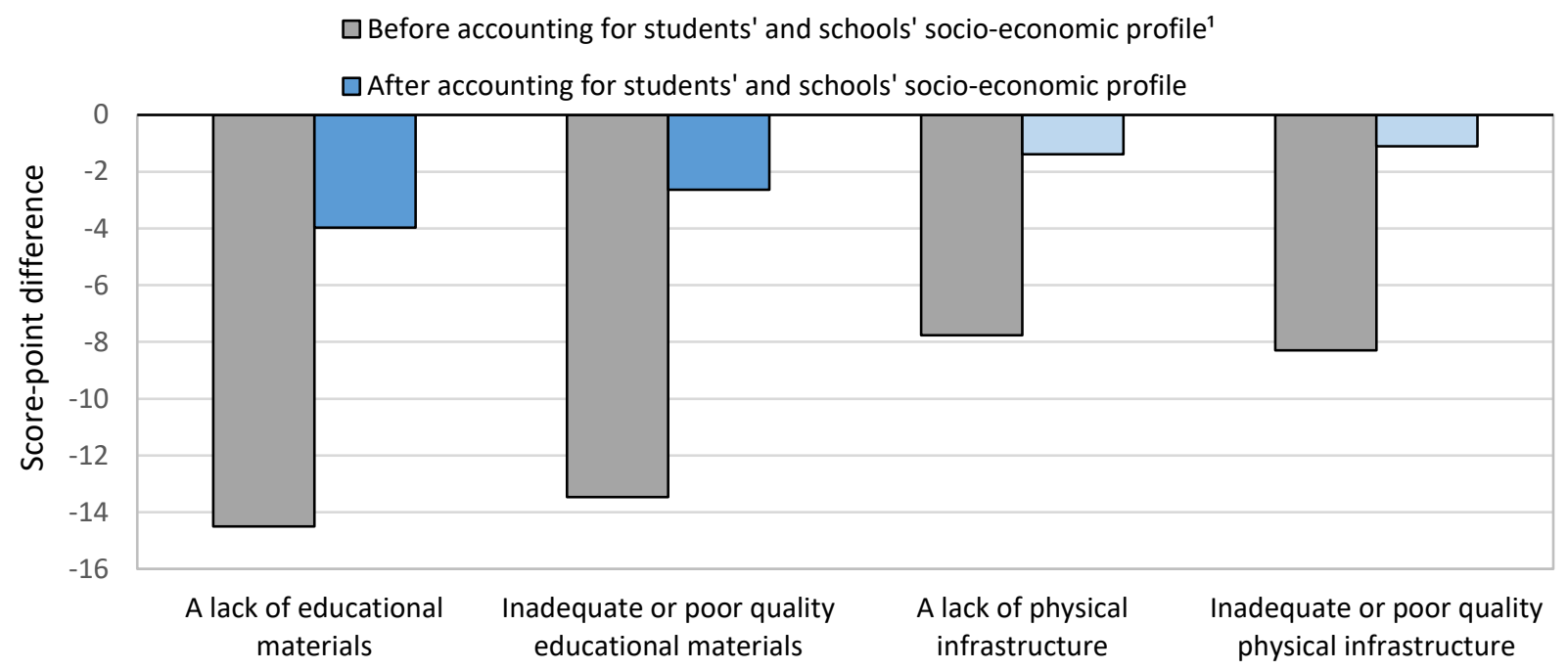

Note: Educational materials include textbooks, ICT equipment, library, laboratory material, etc. Physical infrastructure includes school building, grounds, heating/cooling systems, lighting and acoustic systems, etc. This analysis is restricted to schools with the modal ISCED level for 15year-old students.

Source: OECD $\left(2018_{[155]}\right)$.

64. Finally, technology is only as good as its use. On average across OECD countries, $65 \%$ of $15-$ year-olds are enrolled in schools whose school principals consider that their teachers have the necessary technical and pedagogical skills to integrate digital devices in instruction. Yet, this number varies between socio-economically advantaged and disadvantaged schools (OECD, 2018[155]). In Sweden, for example, the share of teachers with the necessary skills is $89 \%$ in advantaged schools but just $54 \%$ in disadvantaged schools. In this context, providing teachers with useful training in the use of information and communication technologies for pedagogical purposes will allow them to blend effectively digital tools into teaching activities and successfully assist students from lower socio-economic backgrounds. 
65. The fast development of new digital technologies heightens the need to teach students the ability to learn continuously over the working life ("learning to learn"). Only two-thirds of students across the OECD (63\%) showed a growth mind-set (i.e. these students agreed that "your intelligence is something about you that you can change"), which is increasingly critical for more autonomous approaches to learning (OECD, $\left.2020_{[156]}\right)$. Mixing in the school curriculum traditional academic subjects with others, such as entrepreneurial, creative and technical subjects, could help students to develop curiosity and "learning-tolearn" skills $\left(O E C D, 2019_{[157]}\right)$. Protecting education systems from budget cuts and ensuring they have the resources to help all students, irrespective of their socio-economic background, develop strong cognitive and non-cognitive skills is key to building digital skills and the ability to upgrade them over the life course.

\section{Box 3. Lifelong learning - selected policy actions}

Develop inclusive adult learning systems

1. Increase awareness of the importance and availability of adult learning courses, especially among vulnerable groups and make quality information publicly available.

2. Strengthen online training to widen access.

3. Increase funding and financial incentives allocated to employer provided trainings to improve transferable skills, especially for SMEs.

4. Establish quality certification schemes and monitor evaluation systems to ensure value for money while mainlining open competition among training providers.

5. Link part of the financial incentives or fees private-sector training providers receive with the occupational outcomes of training participants.

Create equal opportunities for future workers

6. Equip all schools with digital learning devices and internet access while investing in the development of traditional academic skills (reading, writing and mathematics)

7. Enhance teacher training in the use of information and communication technologies.

8. Adapt school curricula to strengthen non-cognitive skills and students' ability to learn continuously.

9. Ensure the school system has sufficient resources to ensure all students, irrespective of their socio-economic background, can develop strong cognitive and non-cognitive skills.

\subsection{Intangible finance for the knowledge economy}

66. As argued in Section 2, intangible assets are a key complement to digital technologies, as their effective deployment requires large upfront investments in R\&D, patents, managerial and workers' skills, databases, software, designs and organisation and distribution networks (Table 1). The combination of intangibles and digital technologies also can strengthen resilience to shocks, as demonstrated during the COVID-19 crisis in which digitalised and intangible-intensive firms and sectors are likely to have suffered less (Demmou et al., 2021 [4]; OECD, 2021 ${ }_{[114]}$ ). Nonetheless, as for digital technologies, there are large gaps among firms in the build-up of intangible assets, which generate rising productivity dispersion in intangible-intensive sectors (Figure 6, Panel C). 
Table 1. Examples of intangible capital and means of protection

\begin{tabular}{|c|c|c|}
\hline Categories & Types of intangible investment & $\begin{array}{l}\text { Examples of intangible capital } \\
\text { and means of protection }\end{array}$ \\
\hline $\begin{array}{l}\text { Digitized } \\
\text { information }\end{array}$ & Software \& Databases & $\begin{array}{l}\text { Digital capabilities, tools } \\
\text { Trade secrets (data) }\end{array}$ \\
\hline $\begin{array}{l}\text { Innovative } \\
\text { property }\end{array}$ & $\begin{array}{l}\text { Research and Development (R\&D) } \\
\text { Mineral exploration } \\
\text { Entertainment, artistic and literary originals } \\
\text { (E\&AO) } \\
\text { Other new product development (e.g. design, } \\
\text { originals, new financial products) }\end{array}$ & $\begin{array}{l}\text { Patents } \\
\text { Mineral rights } \\
\text { Licenses, contracts } \\
\text { Attributed designs } \\
\text { Trademarks } \\
\text { Trade secrets }\end{array}$ \\
\hline $\begin{array}{l}\text { Economic } \\
\text { competences }\end{array}$ & $\begin{array}{l}\text { Branding } \\
\text { Marketing Research } \\
\text { Organizational structure/business process } \\
\text { investment } \\
\text { Employer-provided training }\end{array}$ & $\begin{array}{l}\text { Brand equity } \\
\text { Market insights, customer lists } \\
\text { Operating models, processes and } \\
\text { systems } \\
\text { Firm-specific human capital } \\
\text { Trademarks }\end{array}$ \\
\hline
\end{tabular}

Note: Operating models include customer platforms, supply chains, distribution networks and after-market services Source: Corrado et al (2021 forthcoming[47]) based on Corrado et al. $\left(2005_{[158]}\right)$.

67. However, intangible assets share characteristics that make their financing more complex. They generally require large and risky initial investments. Asymmetric information and the difficulties in valuing intangible assets make it difficult to pledge them as collateral (OECD, 2021 ${ }_{[114]}$ ). As a result, funding intangible investments through external finance is more challenging than for traditional investment, especially for small and young firms (Berlingieri et al., 2020[45]).

68. There is ample scope for governments to reduce the many obstacles hampering the external financing of intangible investment. OECD (2021 [159]) propose different policy options to improve financing conditions and buttress intangible investment in the short and medium term (Figure 26).

69. In the short term, governments need to ensure that stimulus packages are intangible friendly and lay the foundation for a sustained recovery in productivity growth. As mentioned above, the share of distressed firms has grown during the pandemic. In this context, turning loan guarantees and targeted support schemes into equity-like capital injections for large firms and converting debt into grants for SMEs are critical to restore internal funds and restore firms' ability to invest in intangibles during the recovery. In addition, while governments should preserve "normal times" direct and indirect financial support measures to intangible investment (notably in R\&D) they could re-design them and improve their targeting by better accounting for firms' age and growth potential. Direct government support for innovation can play an important role, often complementary to tax incentives, in narrowing the financing gap in intangibles, especially for young firms lacking alternative financing sources (Hottenrott and Lopes-Bento, 2014 [160]; Mateut, 2018[161]; Appelt et al., 2016[162]; OECD, 2021 [111]).

70. The strong complementarities between digital technologies and skills highlight the importance of upgrading workers and managers' skills. In this area, adult and on-the-job training (as discussed in the previous section), especially of transferable skills that are typically underfunded by private firms, may deserve the same level of support as R\&D investment. Only half of the EU-Members, for instance, have corporate tax incentives for education and training in place (CEDEFOP, 2009 [163]; OECD, 2021 [114]). 
Figure 26. Policy options to make financial systems fit for the rise in intangible investment

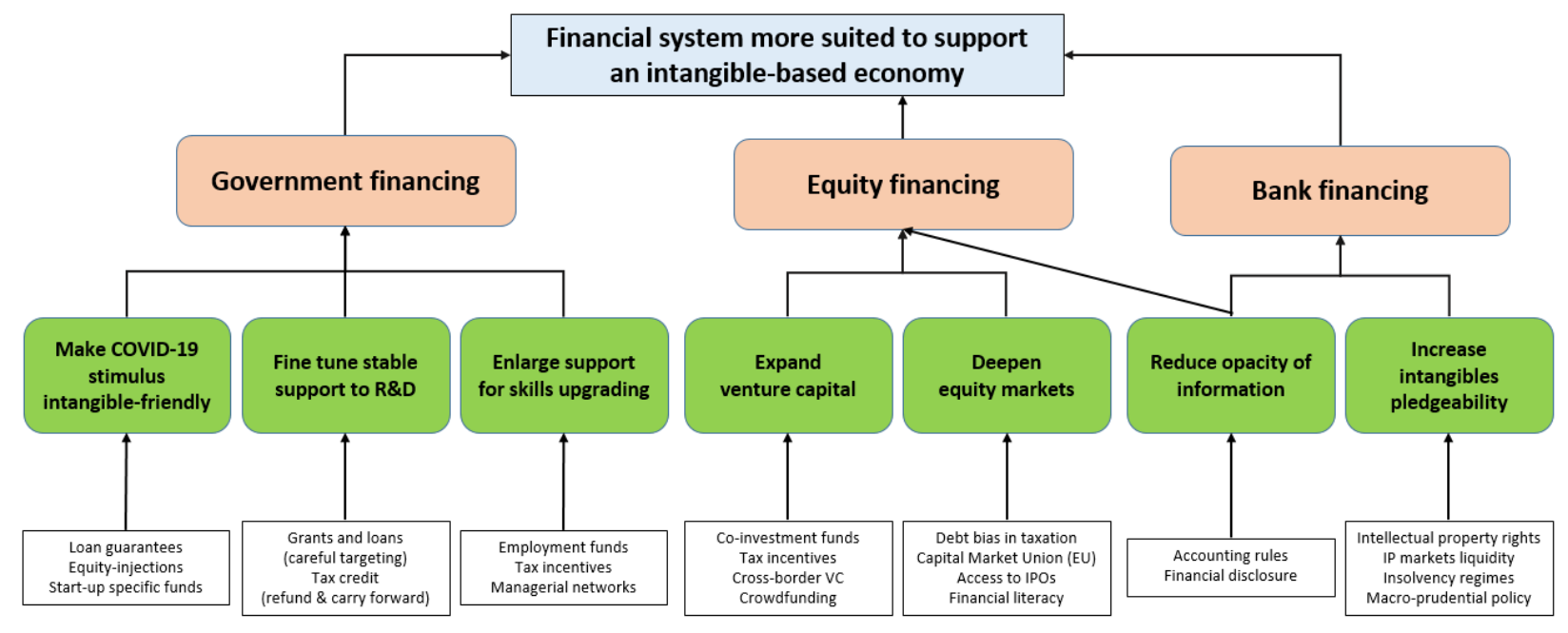

Source: OECD (2021 $[114])$.

71. Turning to financing from the private sector, policies should aim at deepening equity markets and facilitating bank lending for intangible investment. Shareholders are usually a key source of finance for risky projects and firms' development because of their willingness to take risk and ability to evaluate firms based on their growth opportunities rather than the availability of collateral. However, in many OECD and G20 economies, equity markets, along with other channels to raise equity (such as venture capital, private equity, or business angels), remain severely underdeveloped. One way to foster the development of equity markets would be to remove tax advantages favouring debt over equity financing. . Currently, given the low interest rates, the value of interest rate deductions is low, reducing the tax bias towards debt. However, the tax bias would rise with higher interest rates, hampering equity investment. Several G20 and OECD countries have recently introduced allowances for the deduction of a "normal" return on corporate equity to spur equity investment. This includes Brazil, Italy, Italy, Latvia and Portugal. Lowering the fragmentation of equity markets in financial integrated areas (such as in the European Union by progressing with the Capital Market Union), would also help to improve financing for intangible investment. Moreover, OECD and G20 governments could act as a catalyst for private venture capital investments by promoting publicprivate partnerships and establishing a favourable environment to attract foreign investors. In this context improving financial literacy among the managers and owners of the myriad of SMEs could contribute to opening up many of these firms to external capital and diversify their financing away from bank lending towards more risk-tolerant sources of capital.

72. Lastly, measures aimed at improving the collateralisation of intangibles would encourage greater bank lending for intangible investment. In particular, sound intellectual property regimes and liquid intellectual property markets could make it easier to value intangible assets and to pledge them as collateral. Also, a more efficient liquidation of intangible assets in case of insolvency would facilitate bank lending against intellectual property. Finally, reviewing prudential regulation may encourage the development of IP-backed loans as IP currently does not contribute to the calculation of banks' regulatory capital, reducing the incentives for banks to lend money against IP. Complementary to those measures, coordination at international level for the development of common standards to better measure intangible value could reduce informational asymmetry hampering investment in intangible assets.

73. As illustrated by simple simulations (Figure 27), harnessing the potential growth opportunities associated with intangible assets requires the deepening and upgrading of financial systems across OECD and G20 economies. For instance, improving financial development or the size of equity markets by one 
standard deviation, would lead to $2.5-3.5 \%$ increase in productivity in high relative to low intangible intensive sectors (left panel). In a similar vein, easing the collateralisation of intangible assets would benefit the productivity performance of all firms, but especially those with intangible intensity (right panel).

\section{Figure 27. Improving financial systems to harness the growth opportunities associated with intangible assets}

Panel A (left): Financial development and in particular deep equity markets foster productivity in intangible-intensive sectors

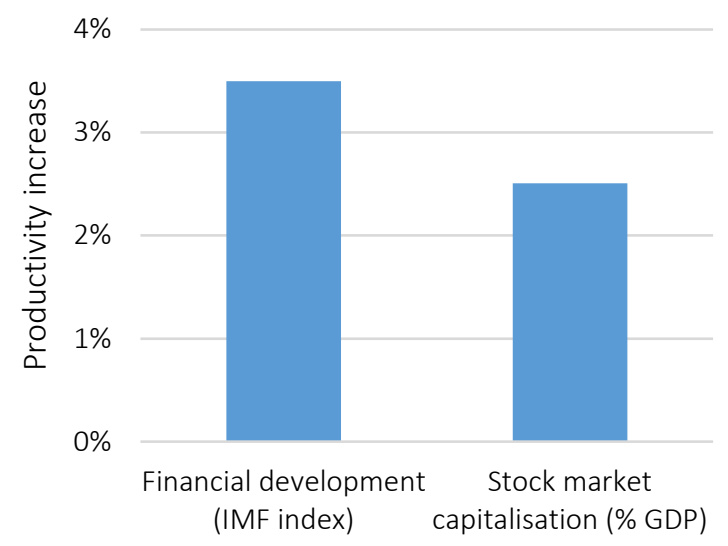

Panel B (right): Increasing collateral availability is more beneficial in intangible-intensive sectors

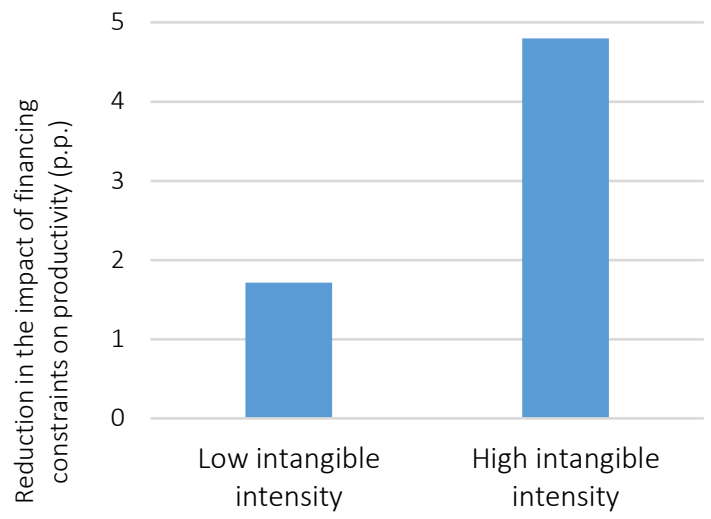

Note: Panel A shows the productivity gains (in high relative to low intangible-intensive sectors). Panel B shows the reduction in the impact of financing constraints on productivity in percentage points in firms with low and high intangible intensity.

Source: OECD (2021 [114]).

\section{Box 4. Intangible investment - selected policy actions}

1. Provide intangible-friendly COVID-19 stimulus packages

2. Ensure the continuity of "normal times" government support, but better account for firms' age and growth potential

3. Upgrade workers' and managers' skills by subsidising on-the-job training

4. Address the tax bias favouring debt over equity financing

5. Equip population with better financial literacy to diversify sources of financing and access external capital

6. Promote public-private partnerships to catalyse private venture capital investments and establish a favourable environment to attract foreign investors

7. Develop international standards to better measure intangible value and reduce informational asymmetry plaguing intangible assets

8. Increase intangibles pledgeability through sound intellectual property regimes, liquid IP markets and IP-backed loans 


\subsection{Framework market conditions for the digital economy}

74. The rising importance of digital technologies has occurred in tandem with signs of rising market concentration across some advanced economies (Figure 28). Big data, the use of algorithms and large network effects generated by digital technologies can give rise to "winner-take-all" dynamics, contributing to rising market concentration and mark-ups. The COVID-19 shock may be exacerbating these trends by shifting activity further towards large digital companies, such as online platforms, and via a wave of distressed small business acquisitions and liquidations in more traditional sectors. Recent evidence, for instance, shows that most areas in the online platform economy are dominated by a few large global platforms (Costa et al., forthcoming[24]) and that business creation has continued the declining trend observed over the past decade, often exacerbated by the COVID-19 crisis. Rising market concentration can slow wage and productivity growth by lowering competitive pressures, increasing monopsony power (OECD, 2008 $[164]$ ) and strengthening lobbying activities (Dellis and Sondermann, 2017[165]).

75. In addition, digitalisation along with globalisation have given rise to challenges for the international taxation system, which allocates taxing rights mainly based on physical presence. In spite of the success of the OECD/G20 Base Erosion and Profit Shifting (BEPS) project, certain BEPS issues remain, many of which are concentrated amongst digital and intangible intensive firms. In addition to depriving the governments of an important source of revenues, such activities may result in an uneven playing field between businesses who have access to tax planning opportunities and those who do not. (Sorbe and Johansson, 2017[166]).

76. To avoid these trends stifling competition and innovation, thus weighing on productivity growth and widening gaps between large and small firms, policies need to ensure that digital markets remain competitive, open and contestable. This requires policy action in four broad areas: 1 ) modernising taxation systems; 2) upgrading competition law and enforcement to the digital age while boosting digital security; 3) supporting business dynamism in digital-intensive sectors; and 4) developing e-government.

\section{Figure 28. Market concentration has increased in Europe and North America}

Differing concentration metrics (CR4, CR8, CR20) in Europe and North America
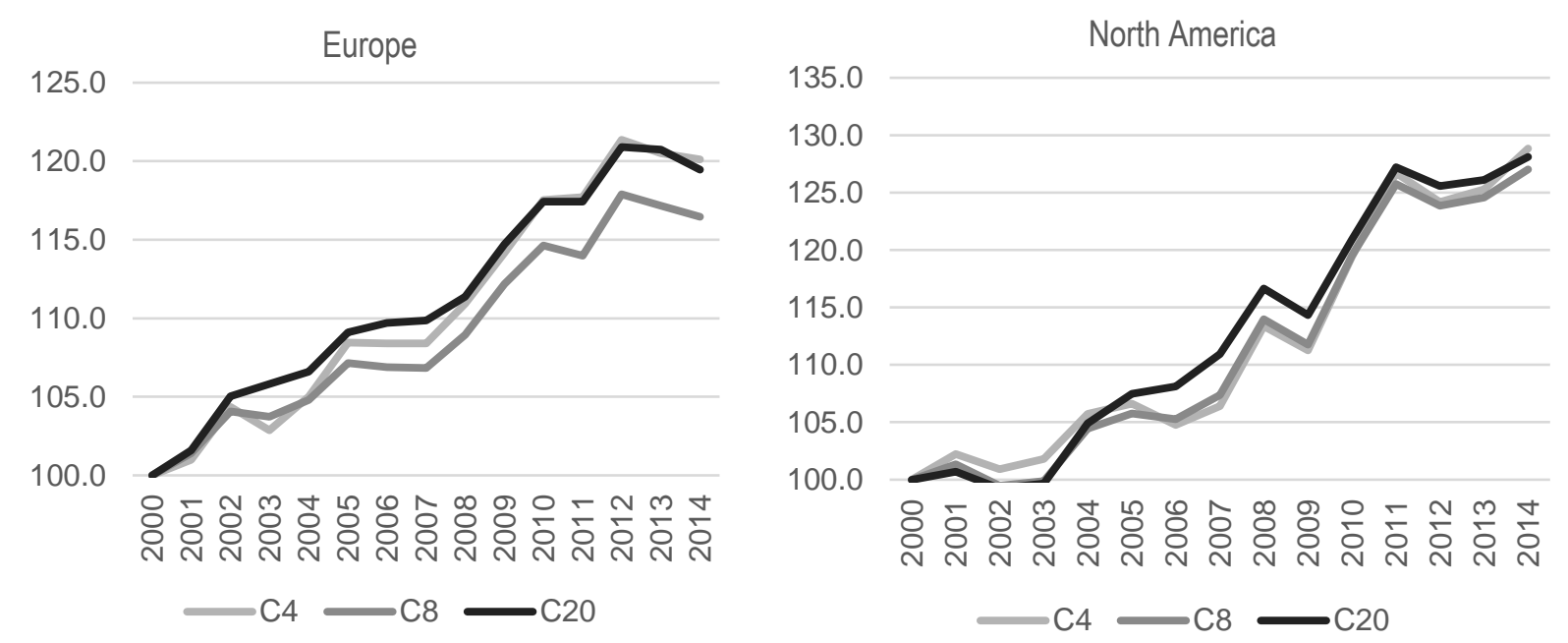

Note: The countries for Europe include BE, DE, DK, EE, ES, FI, FR, GB, GR, HU, IE, IT, LV, NL, NO, PL, PT, SI, SE, and for North America include CA and US. Included industries cover 2-digit manufacturing and non-financial market services. Concentration metrics reflect the share of the top 4, top 8 and top 20 firms in each industry - unweighted metrics (CR4, 8 and 20 respectively). To ensure comparability across different metrics, these now reflect proportional changes. The graphs can be interpreted as the cumulated percentage changes in levels of sales concentration for the mean 2-digit sector within each region. For instance, in 2014 the mean European industry had 20\% higher CR4 sales concentration compared to 2000 .

Source: (Bajgar et al., 2019[106]). 


\subsubsection{Modernising taxation systems}

77. Addressing the challenges to the international tax system linked with digitalisation would have important benefits for revenue and growth. Most jurisdictions still allocate taxing rights principally on the basis of physical presence, which is increasingly outdated in a digitalising economy. In addition, digitalised and intangible intensive businesses may have better access to opportunities to engage in base erosion and profit shifting (BEPS) (Bradbury et al., 2020[167]). These practices may tilt the playing field as they open ways for large and highly digitalised MNE groups to lower their tax payments and gain advantages over smaller competitors and domestic firms. In addition to lowering tax revenues, these practices can also negatively impact tax morale.

78. To improve the coherence of international tax rules and ensure a more transparent tax environment 139 jurisdictions are working together as members of the OECD/G20 Inclusive Framework on Base Erosion and Profit Shifting (BEPS), including through the implementation of BEPS minimum standards. Addressing the tax challenges arising from the digitalisation of the economy has been a top priority of the BEPS Project and the Inclusive Framework since its inception. In January 2019, members of the Inclusive Framework agreed to examine proposals in two pillars, which could form the basis for a consensus solution to the tax challenges arising from digitalisation. Pillar One focuses on nexus and profit allocation rules, whereas Pillar Two is focuses on a global minimum tax and intends to address remaining BEPS issues (OECD, 2020[168]; OECD, 2020[169]). Based on an Economic Impact Assessment carried out by the OECD in 2020, both pillars combined, could increase global corporate tax income (CIT) revenues by about USD 50-80 billion, or USD 60-100, if also taking into account the US Global Intangible Low-Taxed Income (GILTI) regime, the equivalent of $4 \%$ of global CIT revenues (Figure 29 ).

79. By reducing differences in effective tax rates across jurisdictions, the OECD proposal would tend to increase the relative importance of non-tax factors, such as infrastructure, education levels or labour costs, in the investment location decisions of MNEs. The additional revenue the OECD proposal would generate could then be invested to fund programmes to improve infrastructure and education systems or lower taxes on labour, thus supporting inclusive growth.

80. The digital transformation poses additional challenges and opportunities for national tax systems. These changes have raised questions on the fitness of Value Added Taxes/Goods and Services Taxes (VAT/GST) frameworks to efficiently capture online platforms' transactions so as to protect VAT/GST revenue and minimise economic distortions. At the same time, the emergence of online platforms and the availability of big data create new opportunities to enhance tax compliance and administration. 
Figure 29. Estimated effect of the proposals on tax revenues, by jurisdiction groups

Estimates based on illustrative assumptions on the design and parameters of Pillar One and Pillar Two, in \% of CIT revenues

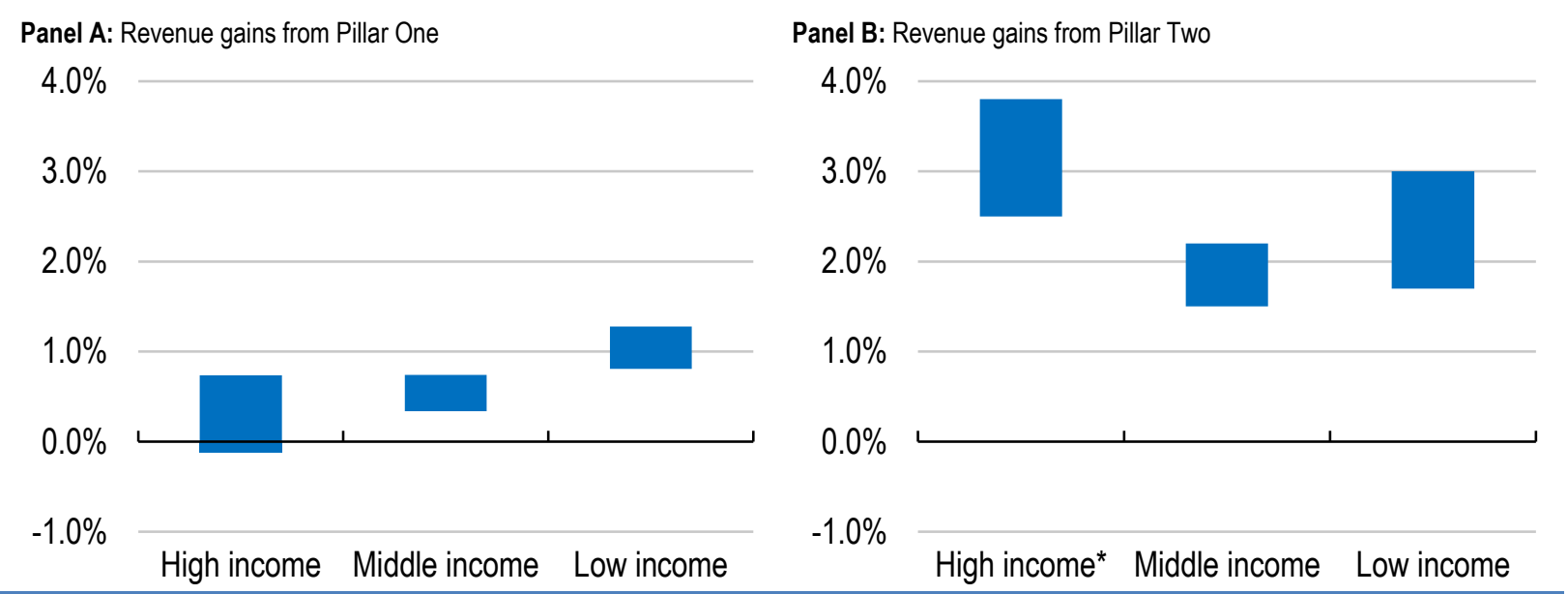

* Excluding the United States (given illustrative assumptionfbusiness that the US GILTI would co-exist with Pillar Two)

Note: The estimates in this figure are based on the following illustrative assumptions. Pillar One is assumed to focus on Automated Digital Services (ADS) and Consumer Facing Businesses (CFB), with a global revenue threshold of EUR 750 million, a profitability threshold percentage of $10 \%$ (based on the ratio of profit before tax to turnover), a reallocation percentage of $20 \%$ and a nexus revenue threshold of EUR 1 million for ADS and EUR 3 million for CFB. Pillar Two is assumed to involve a $12.5 \%$ minimum tax rate with jurisdictional blending and a $10 \%$ combined carve-out on payroll and depreciation expenses. The US GILTI regime is assumed to 'co-exist' with Pillar Two. As a result, the United States is not included in Panel B to ensure greater comparability of results (but it is included in Panel A). Pillar Two estimates take into account the interaction with Pillar One and include gains from a reduction in the profit shifting intensity of MNEs resulting from Pillar Two introduction. Estimates are presented as ranges to reflect uncertainty around the underlying data and modelling. Groups of jurisdictions (high, middle and low income) are based on the World Bank classification. Investment hubs (defined as jurisdictions with a total inward FDI position above $150 \%$ of GDP) are not included in this figure.

Source: OECD (2020[11]).

81. Recent OECD reports put forward a range of policy responses, to be tailored to country specific needs, to tackle the challenges and seize the opportunities the digital transformation engenders for national tax systems (OECD, 2021 [170]; OECD, 2020[171]). On a general level, policy responses need to be consistent with the general rules and principles of jurisdictions' existing VAT/GST systems and ensure an equal treatment of various distribution channels (either traditional or digital). Moreover, managing the increasing number of transactions and economic actors operating in online platforms requires different measures, including: considerations for the determination of a VAT/GST registration and/or collection threshold; presumptive schemes for determining the VAT/GST liability; accounting and reporting simplifications; the use of technology to facilitate VAT/GST administration and compliance; third-party reporting obligations; taxpayer education and other awareness raising activities. A number of complementary measures can enhance the efficient and effective implementation of these policy options, including targeted risk management strategies through extensive use of third party data and international co-operation among tax administration.

\subsubsection{Upgrading competition law and enforcement to the digital age}

82. The competition policy community has begun exploring if changes to existing competition tools are needed to meet the challenges of the digital age. Competition authorities participating in OECD Competition Roundtables have come to the conclusion that several features of the digital economy can be addressed using existing laws and analytical tools, including non-price competition in zero price markets, mergers that affect innovation incentives, vertical mergers, and the use of algorithms to implement collusive agreements (OECD, 2018[172]; OECD, 2017[173]; OECD, 2019 $\left.{ }_{[174]}\right)$. Other features - including 
network effects and multi-sided online platform business models - require authorities to adapt their analytical tools (OECD, 2018[175]).

83. Some digital competition challenges may require more fundamental changes. Competition authorities and policymakers more broadly are still grappling with the possible effects of conglomerate business models (i.e. digital companies building their business model around large ecosystems of complementary products and services) on competitive dynamics (OECD, 2020[176]). A few jurisdictions are also implementing legislative changes to address specific concerns, including ensuring that merger notification criteria allow scrutiny over acquisitions by large incumbents of new or potential entrants before they pose a real threat to their business (OECD, 2020[177]). In the decade to 2019, for instance, the five largest technology firms made over 400 acquisitions (The Economist, 2020[178]).

84. Several governments (such as in Australia, Brazil, Canada, the European Union, France and Germany, Japan, Italy, and Portugal and United States) have commissioned studies of existing competition policy frameworks to determine which changes are needed. Although the exact findings varied across jurisdictions, these studies agree that digital markets represent a unique challenge for competition policy and that other policy areas such as consumer policy have a role to play to preserve market competition. Other concrete changes currently being mooted (although more controversial) include the introduction of a new digital regulator, new enforcement approaches (e.g. a greater use of interim measures to enable more timely responses to potentially anticompetitive conduct), and new merger notification requirements (Mancini, 2019 [179]; Mancini, 2019[180]). Consensus has also emerged on the need for greater international co-operation among competition enforcers and the importance of analyses based on economic evidence (OECD, 2020[12]).

85. Some of these proposals are currently being discussed within the EU with the aim of ensuring a level-playing field between digital service providers and their users. The European Commission has recently put forward, after thorough stakeholder consultations, the Digital Markets Act and the Digital Services Act to reset the digital regulatory framework and to support SMEs in their scaling-up process through better access to customers and lower compliance costs. (European Commission, 2020 [181]).

86. Competition authorities may also need to pay more attention to the role of big data and algorithms. Debates have focussed on whether or not competition laws and agencies should consider big data and algorithms as an asset that can enhance market power and allow firms to engage in anticompetitive behaviour (Boone, Criscuolo and Mancini, 2019 [182]). Algorithms that abet tacit collusion are another potential source of concern, which may require competition agencies to update the traditional concepts of collusive agreements. Questions concern also the opportunity of regulating algorithms and what effects such regulations could have on competition and innovation (OECD, 2017[173]). Addressing these issues calls for closer cooperation between competition, data protection and consumer policy authorities (OECD, 2016[183]; OECD, 2020[184]).

87. Procompetitive regulatory reform can also enhance competition in digital markets. For example, outdated regulation may unnecessarily inhibit new entry and innovation, restricting competition in digital markets. The updated OECD's Competition Assessment Toolkit ${ }^{3}$ provides a detailed methodology for identifying and analysing regulatory barriers to competition taking into account the unique issues that arise in digital markets.

88. An important regulatory measure to promote competition in digital markets focuses on avoiding lock-in effects by allowing users to switch among digital-service providers easily and at low costs. This would require supporting user data portability across digital companies and interoperability (e.g. through open application programming interfaces) of digital services provided by different companies and prohibiting contractual clauses limiting multihoming (i.e. the unfettered freedom of using different providers

\footnotetext{
${ }^{3}$ https://www.oecd.org/competition/assessment-toolkit.htm
} 
at the same time). These provisions could prevent lock-in effects and strengthen market contestability without undermining the benefits of large network effects of successful digital companies. Similar requirements have already been applied in more traditional industries, such as telephone services (possibility of keeping the same telephone number when switching provider) and banking (credit registries allowing to access credit histories).

89. In this sense, the EU General Data Protection Regulation (GDPR) is a step in the right direction as it has introduced the right to data portability for individuals in the European Union. Other prominent data portability initiatives include: the US government's My Data series, launched in 2010, the Green Button energy initiative (US Department of Energy), the Midata data portability initiative of the United Kingdom in 2011 (Department for Business Innovation and Skills (UK), and Australia's CDR legislation (2019) (OECD, $\left.2019_{[185]}\right)$. However, data portability requirements consisting in one-off transfers from one digital company to another at the request of a user (as the GDPR envisages) may not be enough to promote competition. Complementing static data portability (i.e. one-off data transfer) requirements with continuous data portability and interoperability can offer more effective alternatives to boost competition among digital companies while preserving network effects (OECD, 2021 [186]; de Streel, Kramer and Senellart, 2020[187]).

\subsubsection{Supporting business dynamism in digital-intensive sectors}

90. Business dynamism, whereby new firms are born and the best-performing ones thrive and grow, while low performance firms exit, is essential to spread out digital adoption and attract workers to highwage jobs. Policies supporting the mobility of workers from low to high-productivity jobs, especially in digital-intensive sectors, would therefore help to offset and reverse the decade-long decline in business dynamism, which the COVID-19 crisis has aggravated (see Section 2).

91. In this regard, the wider adoption of teleworking practices could incentivize workers to switch to potentially more productive firms located farther away, or even abroad, if those firms no longer require continuous physical presence and frequent commuting. Policies supporting this aim should notably address legal and cultural hurdles, while ensuring investment to strengthen digital infrastructure and skills, especially in rural areas (OECD, 2020[6]). Similar effects can be obtained by easing of licensing and registration requirements, (Bambalaite, Nicoletti and von Rueden, 2020 ${ }_{[188]}$ ), revising housing policies (e.g. by redesigning land-use and planning policies that raise house price differences across locations or relaxing overly strict rental regulations), and imposing a limitation on legal and contractual barriers (e.g. non-poaching agreements (Causa and Pichelman, 2021 [189]; Criscuolo et al., 2021 [71]).

92. COVID-19 also generated both challenges and opportunities for start-ups, which are often more digitalised and innovative. On the one hand, the precipitous drop in economic activity drastically reduced firms' birth in the early stage of the pandemic (Benedetti Fasil, Sedláček and Sterk, 2020[190]). Its durable rebound will hinge on the speed of the recovery and the effectiveness of policies aiming at encouraging entrepreneurship, lowering the costs of firm creation and enhancing business dynamism. Yet, the COVID19 outbreak might also offer opportunities for new innovative firms addressing specific needs related to the pandemic (e.g. tracking and testing) and serving changing consumer preferences (e.g. the demand for telework, e-commerce or online health services). With a view to grasping these opportunities, policy efforts should thus focus on sectors that have proven resilient to COVID-19, including sectors with a high digital intensity. Several countries already introduced measures with a specific focus on start-ups, including a four billion EUR fund to start-up liquidity in France, a tailored start-up programme in Germany or a co-financing round for innovative companies facing financial difficulties in the United Kingdom (OECD, 2020 $\left.{ }_{[15]}\right)$.

93. At the same time, effective insolvency regimes will be key to freeing up workers and assets trapped in less resilient and low productivity firms and facilitate their transition to more digitally equipped and productive ones. The wave of insolvencies that many countries may face in the coming months, as support measures are withdrawn, adds to the urgency of reforming insolvency regimes. However, comparable international data show large differences in the characteristics and effectiveness of insolvency regimes 
across countries. In many countries the restructuring of viable companies is still slow and costly because of difficulties in entering into a composition with creditors (whereby creditors agree on a restructuring plan), the limited ability by creditors to initiate restructuring rather than liquidation and limited use of out-of-court agreements (Adalet McGowan and Andrews, 2018[191]). Empirical evidence suggests that lowering the barriers to corporate restructuring can entail significant benefits, especially for intangible-intensive sectors where the risk of failure is higher due the risky nature of projects and difficulties in accessing finance. (OECD, 2021 [114] $)$. To ameliorate this situation, liquidation could take place in bundles of assets with the aim of preserving synergies across various intangible assets and limit value erosion (OECD, 2021 [159]).

94. Cross-border flows of data are vital to the sharing of information, ideas and knowledge and a backbone to global business and consumer interactions. Evidence is accumulating that cross-border data flows contribute to boosting business dynamism and economic growth. Estimates for the European Union indicate that barriers to cross-border data flows reduce GDP by $0.4-1.1 \%$ ( (van der Marel, Lee-Makiyama and Bauer, 2014[192]; Bauer, Ferracane and Van Der Marel, 2016 [193]). United States International Trade Commission (2014[194]) estimates that the GDP of the United States would be $0.1 \%$ to $0.3 \%$ higher if foreign digital trade barriers were removed. The pandemic has highlighted the usefulness of cross-border data flows for medical research and infection diagnosis in addition to digital services' adoption for business continuity.

95. Cross-border data flows can contribute to level the playing field between large and small companies by helping start-ups and SMEs to expand operations internationally and enabling a new breed of "micro multinationals" (MGI, 2016 $\left.{ }_{[195]}\right)$. The possibility of easily transferring data across borders allow start-ups and SMEs to collect transaction and consumer behaviour data in different jurisdictions and then transfer these data across borders to be stored, aggregated and analysed. Insights from aggregated global data then form the basis of commercial services (e.g. targeted advertising and demand forecasting) offered in multiple locations.

96. Data flows across borders can also support and enhance trust in fair competitive markets by supporting efforts to detect and monitor fraud and money laundering (World Economic Forum, 2020[196]). The 2015 G20 Anti-Corruption Open Data Principles emphasise the potential of free data flows to strengthen collective commitments and efforts across borders to increase public sector transparency and reduce corruption (G20, 2015 $[197])$.

97. However, cross-border data flows raise several legitimate policy concerns relating to privacy protection, data security and data integrity, regulatory control and audit, national security and digital industrial policies. Because of these concerns the number of policies restricting cross-border data flows doubled in the past 10 years as an increasing number of jurisdictions introduced regulatory conditions on transferring data and requirements to store and process data locally (Ferracane, Kren and van der Marel, 2018[198]; OECD, 2021 [199]; World Economic Forum, 2020[200]). For instance, in mid-2020 the European Court of Justice ruled that the "Privacy Shield" is an invalid mechanism for transferring personal data between the European Economic Area and the United States.

98. Data privacy is increasingly recognised as a fundamental value that deserves protection and is deemed as a pre-condition for the flow of data across organisations and borders. Indeed, among respondents to the 2019 OECD Privacy Guidelines Questionnaire, uncertainty regarding legal privacy regimes was the most cited obstacle to cross-border data flows, followed by incompatibility of legal regimes. (OECD, 2020[5]).

99. The proliferation of different data-privacy and security regulations across countries risks fragmenting the international regulatory landscape. This can impose prohibitively high compliance and entry costs on all firms, but especially SMEs, by forcing them to build or lease data centres and comply with different local data regulations. The multiplicity of applicable data regimes also heightens uncertainty for governments, businesses and individuals on the rules applying in a given situation. Moreover, rather than strengthening information security, experts agree that data localization requirements could lower 
companies' ability to ensure cybersecurity or consumer protection, and could facilitate cyberattacks (World Economic Forum, 2020[201]).

100. With the right policies, cross-border data flows can support business dynamism without undermining data privacy and digital security and regulators' access to information. The key challenge is to design privacy and data protection rules that can enable the movement of data across borders with "trust" while contributing to domestic policy interests and objectives. Further progress in sharing experiences on data policy - especially identifying commonalities between existing approaches and instruments used to enable data to flow across borders - could facilitate interoperability of data-privacy and data-transfer frameworks, promoting cross-border data flows with trust. Recent OECD work on cross border data flows could be useful to inform discussions on these issues (Spiezia and Tscheke, 2020[202]; Casalini, López González and Nemoto, 2021[203]; OECD, 2021[204]).

101. Developing common regional and global data privacy and security principles will go in this direction. Implementing internationally recognised security standards and best practices in online security (e.g. ISO 27000 series) would boost trust in other countries' security standards and reduce cybersecurity risks, thereby encouraging cross-border data transfer. Overall, increasing digital security and privacy requires a coordinated government approach, encompassing regulation of different actors, monitoring, increased awareness and skill development (OECD, 2020[5]).

\subsubsection{Advancing digital government policies}

102. The digital transformation of the public administration is crucial to rethink public services and operations from the outset. In line with the OECD Recommendation on Digital Government Strategies (2014[94]) and the G20 Digital Government principles (2018[205]), the strategic use of digital technologies is key to this process and offers the opportunity to develop a more people-driven, transparent and efficient public sector (OECD, 2020[74]). The COVID-19 crisis has underlined the importance of competent and effective use of digital technologies in this area as they have been key to managing emergency responses to the crisis and ensuring continuity of critical public services.

103. The extent to which governments progressed in the digital transformation prior to the COVID-19 shock varies substantially across countries (Figure 30). COVID-19 has catalysed the digital transformation of the public sector, forcing central and subnational governments to adopt a host of new digital initiatives in a wide range of areas, such as infection control or tracking measures, public communication and data sharing, design and delivery of public services and remote working (OECD, 2020[91]).

104. Further progress in the digital transformation will have to consolidate these recent changes and require a coordinated approach to exploit synergies among different initiatives. For instance, enhanced digital public services could ameliorate the matching processes between the unemployed and jobs, as well as foster the development of digital skills that firms need while facilitating interactions with public authorities. Reinforcing public and private employment services to scale up their digital capacities and services, without giving up standard in-person meetings for people with weaker digital skills, would help in this respect $($ OECD, 2020[3]). Making strides in this area would especially benefit SMEs, as the time and resources spent on dealing with inefficient public administrations or overly complex digital services likely account for a larger share of revenues of SMEs than larger enterprises.

105. The use of digital technologies in the public administration and the design of public services accessible through whichever channel a user prefers will require a common IT infrastructure to better integrate processes and data flows, exploit information and eventually improve the public administration's efficiency. This will involve the accumulation and use of large amount of data and improving data governance (OECD, 2019[206]). By adopting an "open-by-default" approach, government could make their data and policy-making processes (including algorithms) available to the public, although this should occur in balance with national and public interests and duly considering ethical issues concerning the accumulation and use of large amount of data (OECD, 2021 [207]) . 
106. Through open government data or open source software projects (i.e. "open-by-default" approach), governments can actively encourage innovation and collaboration with firms and potential startups. The numerous projects that have emerged from open governments data efforts during the pandemic are a testament to the usefulness of this approach (OPSI, 2020[97]). The "open-by-default" and "government-as-a-platform" approaches can enable entrepreneurs (in the public and private sectors) to innovate and further develop and improve digital services, fostering the development of an ecosystem of innovators and start-ups (e.g. GovTech) to solve public problems (OECD, 2020[74]). The 2015 G20 Open Data Principles for Anti-Corruption Free also emphasise the potential of free data flows to strengthen collective commitments and efforts across borders to support greater public sector transparency, and reduce corruption $\left(\mathrm{G} 20,2015_{[197]}\right)$.

\section{Figure 30. The digital transformation of governments is underway but much remains to be done}

\section{OECD Digital Government Index}

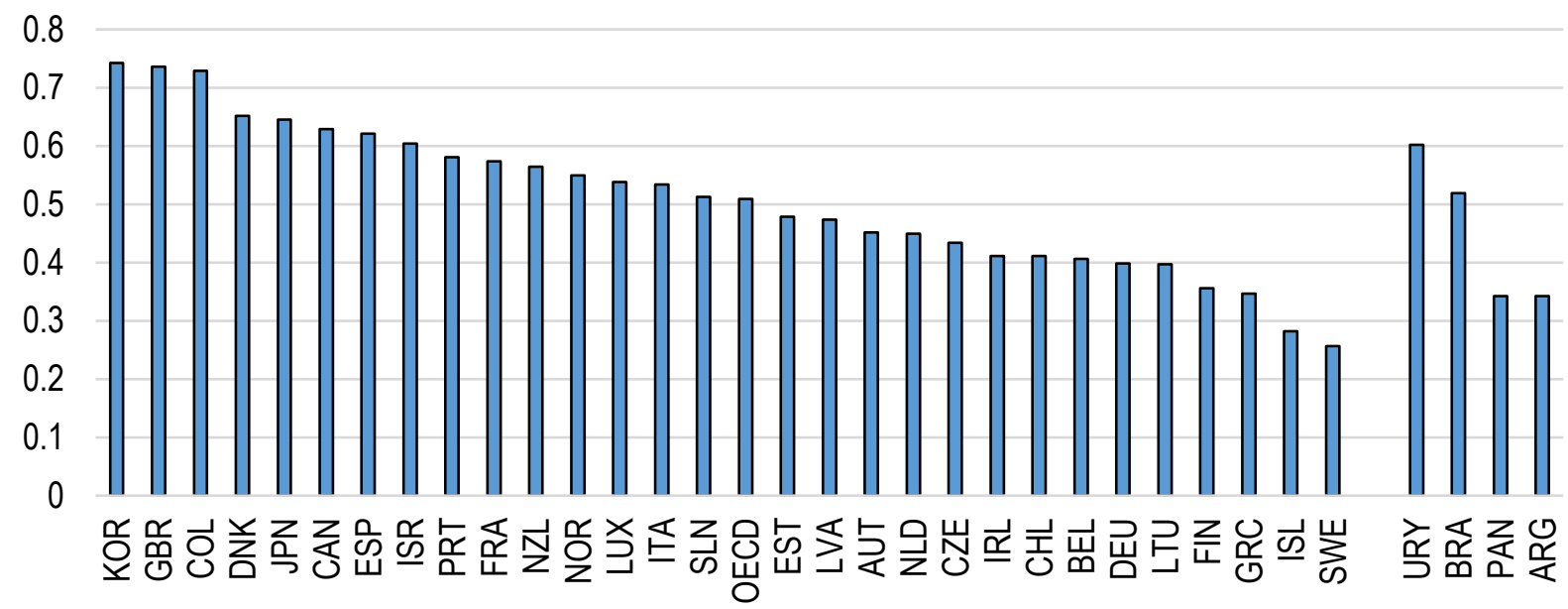

Note: Composite indicator, embedding six dimensions: (1) digital by design, (2) data-driven public sector; (3) government as a platform, (4) open by default, (5) user-driven, (6) proactiveness.

Source: OECD Survey on Digital Design 2.0, forthcoming.

107. The Covid-19 crisis has also highlighted that data collected by digital companies can be an important input to advance digital government policies. Perhaps the most striking example comes from data collected by telephone networks and online platforms. These have been essential in assessing the level of compliance with mobility restrictions and identifying the sectors most affected by lockdowns (OECD, 2021 [8]; OECD, 2021 [199]).

108. On a general level, data from digital companies hold the promise of improving official statistics, making them more timely, accurate and salient. They can provide policymakers with a more accurate picture of key macroeconomic variables such as consumption, prices and productivity. However, the engagement of official statistics offices with the private sector is still sporadic and fragmented due to the lack of a mutually trusted governance framework (OECD, 2019 $\left.{ }_{[185]}\right)$. Building such a governance frameworks is a pre-condition to strengthen engagements between statistical offices and the private sector and unlock coordinated flows of data while meeting high confidentiality and privacy standards. Agreeing at the G20 level on a set of high-level principles to develop this governance framework can strengthen commitments and accelerate the development of public-private data partnerships for the production of official statistics. 


\section{Box 5. Framework conditions - selected policy actions}

- Modernize antitrust law by adopting new analytical tools to address specific features of the digital economy (e.g. network effects and multi-sided online platform business models).

- Encourage competition enforcers to engage in greater international co-operation and further rely on analyses based on economic evidence rather than mere presumptions of competitive harm.

- Promote data portability and multi-homing initiatives to facilitate the switching between providers.

- Continue to update the international tax rules by seeking a global agreement to address the tax challenges arising from the digitalisation and globalisation of the economy through the OECD/G20 Inclusive Framework on Base Erosion and Profit Shifting (BEPS).

- Improve the design of insolvency regimes to facilitate restructuring and limit the loss of intangible assets associated with liquidation procedures.

- Support start-ups in sectors with a high digital intensity, and ensure the continuity of support throughout all early stages of firm development.

- Promote international coordination to support cross-border data flows while ensuring data privacy and security and regulators' access to information.

- Advance digital government strategies, including through open government and open data initiatives and through developing mutually trusted governance frameworks to share data with the private sector.

\subsection{Technology access via digital infrastructure}

109. Communication networks have been central to effective responses to the pandemic and facilitated the continuation of economic activity. With more than 1.3 billion citizens of OECD countries alone working and studying from home, internet traffic increased by as much as $60 \%$ along Internet Exchange Points (including fixed and mobile broadband operators, content and cloud providers, and points where Internet networks connect to each other to exchange traffic (Figure 31). In Italy, for instance, Telecom Italia experienced a traffic increase of $63 \%$ and $36 \%$ in the fixed and mobile network, respectively in the early months of the pandemic. In this unprecedented situation, the universal availability of resilient broadband networks has become more critical than ever before.

\section{Figure 31. Increase in domestic bandwidth production across $\mathrm{G} 20$ countries}

Bandwidth produced at Internet exchange points (Terabits per second)

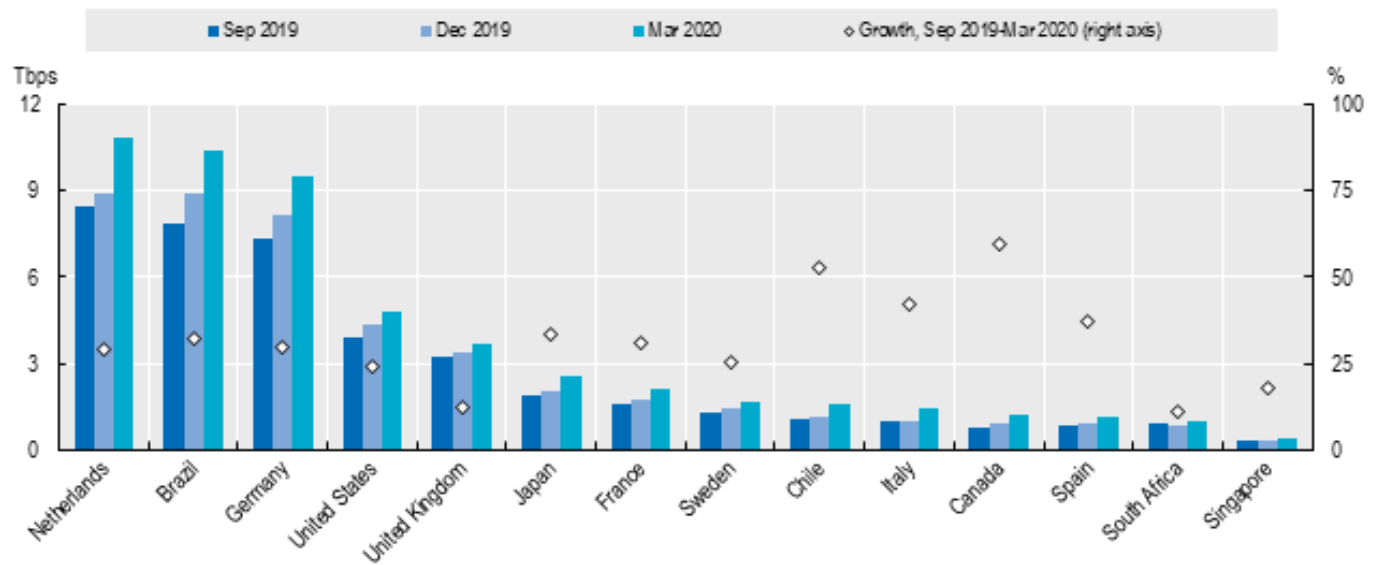

Note: Tbps $=$ Terabits per second. Data show the median IXP peak traffic aggregated by country in September 2019, December 2019 and March 2020, based on public sources. For Canada, data may not capture all Internet traffic as Canadian ISPs do not rely exclusively on public IXPs to exchange traffic, and often leverage on private direct exchange (transit) with content providers.

Source: OECD calculations based on data from PCH (2020[208]) and OECD (2020[18] $)$. 
110. In addition to maintaining business operations and social interactions, access to high-speed internet supports firms' productivity growth directly as well as indirectly, by enabling the adoption of productivity-enhancing digital technologies such as cloud computing (Sorbe et al., 2019 [25]; Nicoletti, von Rueden and Andrews, 2020[143]). Raising the number of firms adopting high-speed internet connections (> $30 \mathrm{Mbps}$ ) to the best performing country, for instance, could increase productivity gains within firms by up to $6.5 \%$ over three years, with half the gains accruing from indirect benefits (Figure 32). With SMEs lagging behind large firms in terms of connectivity (Figure 5, Panel B), these gains would also contribute to closing digital divides and the related productivity and income gaps.

111. At the same time, the evolving complexity of digital technologies and a growing share of activities requiring high-speed internet connections (e.g. video streaming services, multiple screens services and home-connected devices) constantly increases the demand for broadband connections. Internet of Things (IoT), artificial intelligence and other applications will further accelerate this trend in the coming years. By 2022, there will be three connected devices per person around the globe (OECD, 2019[209]).

112. Moving towards high-capacity fixed networks (Gigabit networks), and the next generation of wireless networks (i.e. 5G), while phasing out XDSL technologies, will be necessary to meet this surging demand. Fixed and wireless networks are usually seen as substitutes but there are important complementarities between them. As the amount of data exchanged on wireless connections rises, the speed of these connections will ultimately hinge on the capacity of fixed networks and backbone facilities. Further investment in fibre backhaul is then increasingly important. Taking fibre backhaul closer to end users, whether a business or a residence, will increase Internet speed across all technologies (OECD, 2019[209]; OECD, 2020[5]).

\section{Figure 32. High-speed broadband is associated with higher productivity}

Effect on productivity from closing half of the gap in the take up of high-speed internet broadband with best performing country

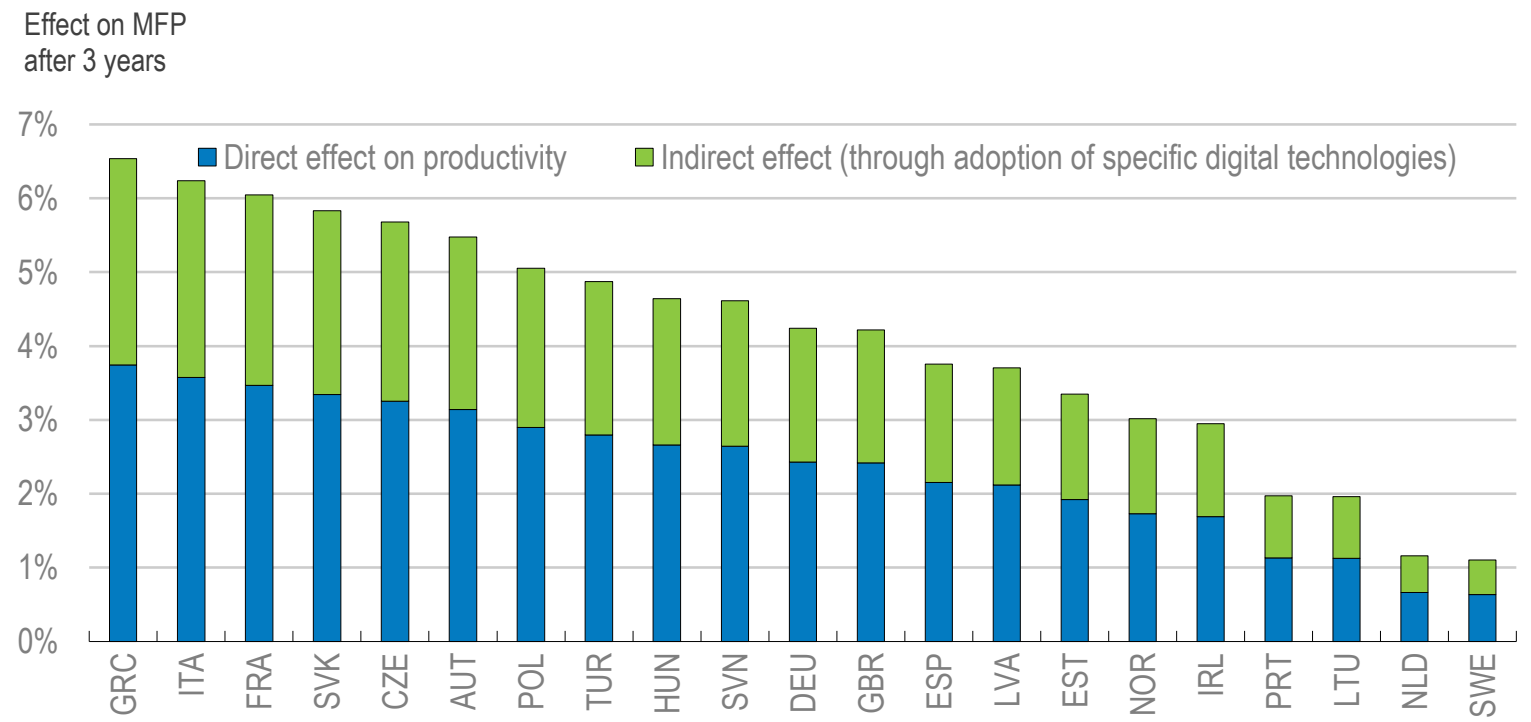

Notes: Estimated effect on multi-factor productivity (MFP) of the average firm after three years from increasing high-speed broadband access $(>30 \mathrm{Mb} / \mathrm{s})$ to close half of the gap with the best performing country in the sample (Denmark). The indirect effect captures the productivity benefits from increased adoption of cloud computing, Enterprise Resource Planning (ERP) and Customer Relationship Management (CRM) software resulting from faster internet access. The direct effect corresponds to other sources of productivity gains, either directly related to faster internet access or resulting from adoption of other digital technologies.

Source: Sorbe et al. $\left(2019_{[25])}\right.$. 
113. A number of demand and supply side policies are relevant to enhance communication networks and widen access to them between and within countries as underlined by the recently revised OECD Recommendation on Broadband Connectivity (OECD, 2021[210]). More in detail, governments may need to invest directly in high-speed networks and improve incentives for private enterprises to invest, especially in rural and remote places (OECD, 2020[40]). Improving the capacity of sub-national governments is important in those countries where they account for a large share of total public investment (de Mello and Ter-Minassian, 2020[211]), such as Canada and Australia. Some concrete examples of ways in which governments can reduce such gaps in the digital divide include encouraging the development of solutions at the local level (e.g. through locally owned co-operatives and municipal networks), simplifying subsidies, using auction-based subsidy programs to deliver next generation technologies, encouraging competition in the provision of local public services, and encouraging risk-sharing through public-private partnerships (OECD, 2021 [212]).

114. Ensuring dynamic and competitive telecommunication markets, by encouraging the emergence of new entrants and lowering barriers to trade and investment, can spur investment in communication infrastructure while lowering fees. For instance, in Mexico following the opening up of the telecommunication industry started in 2013 , prices for mobile services decreased significantly between 2012 and 2016 (by over 60\%), leading to over 50 million new mobile Internet connections and a fourfold increase in the number of people using the Internet for online transactions (OECD, 2017[213]).

115. Restrictions to foreign entry and barriers to competition are the most prevalent restrictions according to the OECD Telecommunication Services Trade Restrictiveness Index and account for most of its variation across countries. Specific policy initiatives involve voucher programmes and targeted subsidies, competitive tenders for private-sector network deployment, tax incentives, low-interest loans, lower spectrum fees and implementing open access and infrastructure-sharing arrangements. More generally, a supportive regulatory environment can also be conducive to spurring investment and lowering prices. This is illustrated by Korea, which was able to achieve high broadband penetration rates earlier than other countries due to a mix of supply and demand side policies including highly competitive markets; clear strategic plans guiding public investment; incentives for private investment (e.g.: low interest loans for network roll-out in rural areas); free internet access centres in remote areas; and a regulatory approach responsive to changing market conditions.

116. Streamlining administrative procedures - for instance to secure "rights of way" to dig up streets is also important to build and enhance key infrastructure such as the deployment of many small cells for $5 \mathrm{G}$ and their backhaul connections. For example, Germany and Switzerland have taken measures to strengthen coordination of civil works across municipalities. By defining presumptively reasonable time for local authorities to grant or deny different permit applications, the United States' Federal Communication Commission can substantially accelerate the pace of $5 \mathrm{G}$ deployment. The development of $5 \mathrm{G}$ wireless networks depends also on the efficient allocation of the spectrum while infrastructure sharing can help to mitigate investment costs (OECD, 2019[214]; OECD, 2020[5]).

117. Many countries already bundle national infrastructure targets in dedicated digital strategies. In 2019, 34 out of 37 OECD countries had an overarching national digital strategy (NDS), in which the development of telecommunication infrastructure consistently ranks among the top priorities (OECD, $\left.2020_{[5]}\right)$. In this context, almost all OECD countries have established broadband access targets, and in some cases, usage targets. Korea, for example, has the highest target for download speeds (10 Gigabits per second (Gbps) to $50 \%$ of urban households by 2022), which likely explains the composition of broadband subscriptions illustrated in Figure 4. Several OECD countries even changed their legal frameworks to include broadband as part of their universal service framework, including Australia, Belgium, Canada, Finland, Spain, Switzerland, Sweden and Korea among many others. Since 2017, many OECD countries also issued national $5 \mathrm{G}$ strategies, or embedded a vision of $5 \mathrm{G}$ in their broadband strategies. In this context, the Austrian 5G Strategy, for example, explicitly aims to close infrastructure gaps between rural and urban areas. The set of solutions to improve the availability and affordability of broadband 
infrastructure will differ by country, whether it is addressing regulations or providing public sector support and incentives, but overall NDS has proven to be a useful tool to define policy priorities, set objectives and outline actions for implementation.

118. Regulators and policy-makers are increasingly recognising the need to monitor the quality of infrastructure networks - resilience to shocks, interruption of services, actual versus advertised speed as this is crucial to support the effective use of digital technologies. Initiatives involve mainly using information on actual data usage and transfer, or data-driven regulation. One of their major benefits is to increase market transparency and extending competition beyond prices to quality. For instance, in France the communication regulator (Acerp) aims at providing users with information on data coverage and quality of communication networks. Germany, Korea and Austria have also started similar initiatives (OECD, 2020[5]).

\section{Box 6. Technology access - selected policy recommendations}

- Promote competition and remove barriers to investment to boost connectivity.

- Expand coverage in rural areas, encourage private investment through incentives (such as competitive tendering, tax incentives, lower spectrum fees, or loans at a reduced interest rate, community-led programs and municipal networks) or invest directly where it is not commercially viable.

- Develop and implement broadband development plans and usage targets.

- Adopt tools, such as data-driven regulation, to monitor quality of communication networks in addition to fees and prices. 


\section{References}

Adalet McGowan, M. and D. Andrews (2018), "Design of insolvency regimes across countries", OECD Economics Department Working Papers, No. 1504, OECD Publishing, Paris, https://dx.doi.org/10.1787/d44dc56f-en.

Adalet McGowan, M., D. Andrews and V. Millot (2017), "Insolvency Regimes, Technology Diffusion and Productivity Growth : Evidence from Firms in OECD Countries", OECD Economics Department Working Papers, No. 1425, OECD Publishing, Paris, https://dx.doi.org/10.1787/36600267-en.

Adalet McGowan, M., D. Andrews and V. Millot (2017), "Insolvency regimes, zombie firms and capital reallocation", OECD Economics Department Working Papers, No. 1399, OECD Publishing, Paris, https://dx.doi.org/10.1787/5a16beda-en.

Adams-Prassl, A. et al. (2020), Inequality in the Impact of the Coronavirus Shock: Evidence from Real Time Surveys, IZA Discussion Paper Series.

Allen, R. (2012), The British industrial revolution in global perspective, Cambridge University Press, http://dx.doi.org/10.1017/CBO9780511816680.

Andrews, D., C. Criscuolo and P. Gal (2016), "The Best versus the Rest: The Global Productivity Slowdown, Divergence across Firms and the Role of Public Policy", OECD Productivity Working Papers, No. 5, OECD Publishing, Paris, https://dx.doi.org/10.1787/63629cc9-en.

Andrews, D. and A. de Serres (2012), "Intangible Assets, Resource Allocation and Growth: A Framework for Analysis", OECD Economics Department Working Papers, No. 989, OECD Publishing, Paris, https://dx.doi.org/10.1787/5k92s63w14wb-en.

Andrews, D. et al. (2020), The career effects of labour market conditions at entry", OECD [125] Publishing, Paris.

Andrews, D., G. Nicoletti and C. Timiliotis (2018), "Digital technology diffusion: A matter of capabilities, incentives or both?", OECD Economics Department Working Papers, No. 1476, OECD Publishing, Paris, https://dx.doi.org/10.1787/7c542c16-en.

Appelt, S. et al. (2016), "R\&D Tax Incentives: Evidence on design, incidence and impacts", OECD Science, Technology and Industry Policy Papers, No. 32, OECD Publishing, Paris, https://dx.doi.org/10.1787/5j|r8fldqk7j-en.

Autor, D. and B. Price (2013), "The Changing Task Composition of the US Labor Market: An Update of Autor, Levy, and Murnane (2003)", MIT Working Paper June 2013.

Azevedo, J. et al. (2020), Simulating the Potential Impacts of COVID-19 School Closures on Schooling and Learning Outcomes, World Bank, http://pubdocs.worldbank.org/en/798061592482682799/covid-and-education-June17-r6.pdf. 
Bailin Rivares, A. et al. (2019), "Like it or not? The impact of online platforms on the productivity [221] of incumbent service providers", OECD Economics Department Working Papers, No. 1548, OECD Publishing, Paris, https://dx.doi.org/10.1787/080a17ce-en.

Bajgar, M. et al. (2019), "Industry Concentration in Europe and North America", OECD Productivity Working Papers, No. 18, OECD Publishing, Paris, https://dx.doi.org/10.1787/2ff98246-en.

Bambalaite, I., G. Nicoletti and C. von Rueden (2020), "Occupational entry regulations and their effects on productivity in services: Firm-level evidence", OECD Economics Department Working Papers, No. 1605, OECD Publishing, Paris, https://dx.doi.org/10.1787/c8b88d8b-en.

Barrero, J., N. Bloom and S. Davis (2020), COVID-19 IS ALSO A REALLOCATION SHOCK, NBER Working Paper, https://www.nber.org/system/files/working papers/w27137/w27137.pdf.

Bauer, M., M. Ferracane and E. Van Der Marel (2016), Tracing the Economic Impact of Regulations on the Free Flow of Data and Data Localization, Centre for International Gouvernance Innovation Paper No. 30,, https://www.cigionline.org/publications/tracingeconomic-impact-regulations-free-flow-data-and-data-localization (accessed on 23 April 2021).

Beck, T. (ed.) (2018), "The walking dead? Zombie firms and productivity performance in OECD countries", Economic Policy, Vol. 33/96, pp. 685-736, http://dx.doi.org/10.1093/epolic/eiy012.

Benedetti Fasil, C., P. Sedláček and V. Sterk (2020), EU start-up calculator: impact of COVID-19 on aggregate employment, European Commission JRC Technical Report, http://dx.doi.org/10.2760/049945.

Berlingieri, G. et al. (2020), "Laggard firms, technology diffusion and its structural and policy determinants", OECD Science, Technology and Industry Policy Papers, No. 86, OECD Publishing, Paris, https://dx.doi.org/10.1787/281bd7a9-en.

Bessen, J. and R. Hunt (2007), "An Empirical Look at Software Patents", Journal of Economics Management and Strategy, Vol. 6/1, pp. 157-189.

Bessen, J. and E. Maskin (2009), "Sequential innovation, patents, and imitation", The RAND Journal of Economics, Vol. 40/4, pp. 611-635, http://dx.doi.org/10.1111/j.17562171.2009.00081.x.

Bianchi, N., Y. Lu and H. Song (2020), The Effect of Computer-Assisted Learning on Students' Long-Term Development, National Bureau of Economic Research, Cambridge, MA, http://dx.doi.org/10.3386/w28180.

Bloom, N., S. Davis and Y. Zhestkova (2020), "COVID-19 Shifted Patent Applications Toward Technologies that Support Working from Home", SSRN Electronic Journal, http://dx.doi.org/10.2139/ssrn.3695191.

Bonadio, B. et al. (2020), Global Supply Chains in the Pandemic, NBER Working Paper No. 27224, http://dx.doi.org/10.3386/w27224.

Boone, L., C. Criscuolo and J. Mancini (2019), Competition in the digital age, https://oecdecoscope.blog/2019/05/31/competition-in-the-digital-age/ (accessed on 26 January 2021). 
Bounie, D. et al. (2020), Dynamiques de consommation dans la crise :les enseignements en temps réel des données bancaires, Conseil d'analyse économique.

Bradbury, D. et al. (2020), Tax challenges from digitalisation: A global two-pillar solution could increase tax revenues and support economic activity, OECD Ecoscope Blog, https://oecdecoscope.blog/2020/10/20/tax-challenges-from-digitalisation-a-global-two-pillarsolution-could-increase-tax-revenues-and-support-economic-activity/.

Brekelmans, S. and G. Petropoulos (2020), Occupational change, artificial intelligence and the geography of EU labour markets, Working Paper Bruegel.

Broadberry, S. and K. O' Rourke (2010), The Cambridge Economic History of Modern Europe Volume 21870 to the Presernt, Cambridge University Press, https://www.cambridge.org/core/series/cambridge-economic-history-of-moderneurope/0A79E0A8C2D0B76F757B9B5798DBE083 (accessed on 10 December 2020).

Brynjolfsson, E. et al. (2008), "Scale Without Mass: Business Process Replication and Industry Dynamics”, SSRN Electronic Journal, http://dx.doi.org/10.2139/ssrn.980568.

Brynjolfsson, E., D. Rock and C. Syverson (2018), "The Productivity J-Curve: How Intangibles Complement General Purpose Technologies", NBER Working Paper 25148, http://www.nber.org/papers/w25148 (accessed on 9 December 2020).

Calvino, F., C. Criscuolo and R. Verlhac (2020), "Declining business dynamism: Structural and policy determinants", OECD Science, Technology and Industry Policy Papers, No. 94, OECD Publishing, Paris, https://dx.doi.org/10.1787/77b92072-en.

Cameron, R. (1975), "The Diffusion of Technology as a Problem in Economic History", Economic Geography, Vol. 51/3, p. 217, http://dx.doi.org/10.2307/143118.

Casalini, F., J. López González and T. Nemoto (2021), "Mapping commonalities in regulatory approaches to cross-border data transfers", OECD Trade Policy Papers, No. 248, OECD Publishing, Paris, https://dx.doi.org/10.1787/ca9f974e-en.

Causa, O. and J. Pichelman (2021), Should I stay or should I go? Housing and residential mobility across OECD countries, OECD Publishing (forthcoming).

CEDEFOP (2009), Using Tax Incentives to Promote Education and Training, Cedefop panorama series.

Cette, G. et al. (2020), Economic Adjustment during the Great Recession: The Role of Managerial Quality, NBER Working Paper, http://10.3386/w27954.

Cohen, W., R. Nelson and J. Walsh (2000), Protecting Their Intellectual Assets: Appropriability Conditions and Why U.S. Manufacturing Firms Patent (or Not), National Bureau of Economic Research, Cambridge, MA, http://dx.doi.org/10.3386/w7552.

Comin, D. and M. Mestieri (2018), "If Technology Has Arrived Everywhere, Why Has Income Diverged? †", American Economic Journal: Macroeconomics, Vol. 10/3, pp. 137-178, http://dx.doi.org/10.1257/mac.20150175.

Conti, A., J. Thursby and M. Thursby (2013), "Patents as Signals for Startup Financing", The Journal of Industrial Economics, Vol. 61/3, pp. 592-622. 
Corrado, C. et al. (2021 forthcoming), New Evidence on Intangibles, Diffusion and Productivity, https://one.oecd.org/document/DSTI/CIIE/WPIA(2020)6/en/pdf.

Corrado, C., C. Hulten and D. Sichel (2005), Measuring Capital in the New Economy, University of Chicago Press.

Costa, H. et al. (forthcoming), Are online platforms killing the offline stars? Platform diffusion and the productivity of traditional firms, Paper presented at the OECD WP1 meeting on the 22 October 2020, ECO/CPE/WP1(2020)6.

Costa, H. et al. (forthcoming), "Welcome to the (digital) jungle: a new cross-country measure of online platform diffusion".

Criscuolo et al. (2021), The firm-level link between productivity dispersion and wage dispersion: A symptom of low job mobility?, OECD Economics Department Working Papers No. 1656.

Criscuolo, C. et al. (2020), "Workforce composition, productivity and pay: the role of firms in wage inequality", OECD Economics Department Working Papers, No. 1603, OECD Publishing, Paris, https://dx.doi.org/10.1787/52ab4e26-en.

Criscuolo, C. and J. Timmis (2018), "GVC centrality and productivity: Are hubs key to firm performance?", OECD Productivity Working Papers, No. 14, OECD Publishing, Paris, https://dx.doi.org/10.1787/56453da1-en.

CSIS (2018), Exploring the Potential of Digitalization fro Inclusive Socio-Economic Development in Eastern Indonesia, Centre for Strategic and a nd International zstudies \& Facebook, http://www.csis.or.id.

David, P. (1990), The dynamo and the computer: An historical perspective on the modern productivity paradox, American Economic Association, http://dx.doi.org/10.2307/2006600.

Davis, M., A. Ghent and J. Gregory (2021), The Work-at-Home Technology Boon and its Consequences, NBER Working Paper, http://dx.doi.org/10.3386/w28461.

de Mello, L. and T. Ter-Minassian (2020), Digitalisation Challenges and Opportunities for Subnational Governments, OECD Working Papers on Fiscal Federalism.

de Streel, A., J. Kramer and P. Senellart (2020), Making data portability more effective for the digital economy, Centre on Regulation in Europe, https://cerre.eu/publications/report-makingdata-portability-more-effective-digital-economy/ (accessed on 3 June 2021).

Dellis, K. and D. Sondermann (2017), Lobbying in Europe: new firm-level evidence, European Central Bank Working Paper Series, https://www.ecb.europa.eu/pub/pdf/scpwps/ecb.wp.2071.en.pdf.

Demmou, L. et al. (2021), "Insolvency and debt overhang following the COVID-19 outbreak: Assessment of risks and policy responses", OECD Economics Department Working Papers, No. 1651, OECD Publishing, Paris, https://dx.doi.org/10.1787/747a8226-en.

Demmou, L. and G. Franco (2021), Intangible assets and productivity: mind the financing gap!, OECD Economics Department working paper (forthcoming). 
Demmou, L., I. Stefanescu and A. Arquie (2019), "Productivity growth and finance: The role of intangible assets - a sector level analysis", OECD Economics Department Working Papers, No. 1547, OECD Publishing, Paris, https://dx.doi.org/10.1787/e26cae57-en.

di Mauro, F. and C. Syverson (2020), The COVID crisis and productivity growth, VOX EU Blog, https://voxeu.org/article/covid-crisis-and-productivity-growth.

Dieppe, A. (2020), Global Productivity : Trends, Drivers, and Policies, Washington, DC: World Bank, https://openknowledge.worldbank.org/handle/10986/34015 License: CC BY 3.0 IGO.".

Dinerlosz, E. et al. (2021), Business Formation: A Tale of Two Recessions, Center for Economic Studies (CES), https://www2.census.gov/ces/wp/2021/CES-WP-21-01.pdf.

EU (2020), Mobile contact tracing apps in EU Member States, https://ec.europa.eu/info/livework-travel-eu/coronavirus-response/travel-during-coronavirus-pandemic/mobile-contacttracing-apps-eu-member-states en (accessed on 27 March 2021).

Eurofound (2020), Living, working and COVID-19 dataset, Dublin, http://eurofound.link/covid19data.

Eurofound (2017), Sixth European Working Conditions Survey - Overview report (2017 update), http://dx.doi.org/10.2806/784968.

European Commission (2020), Europe fit for the Digital Age: Commission proposes new rules for digital platforms, Press Release, https://ec.europa.eu/commission/presscorner/detail/en/ip 202347.

Fadic, M., P. Garda and M. Pisu (2019), "The effect of public sector efficiency on firm-level productivity growth: The Italian case", OECD Economics Department Working Papers, No. 1573, OECD Publishing, Paris, https://dx.doi.org/10.1787/6d20b56d-en.

Falentina, A. et al. (2019), Digitalization and the performance of micro and small enterprises in Yogyakarta, Indonesia, https://crawford.anu.edu.au/publication/working-papers-trade-anddevelopment/14343/digitalization-and-performance-micro-and.

Faquet, R. and V. Malardé (2020), Digitalisation in France's business sector, Direction générale du Trèsor, Ministère de l'Economie et des Finances, https://www.tresor.economie.gouv.fr/Articles/2020/11/26/digitalisation-in-france-s-businesssector (accessed on 27 April 2021).

Ferracane, M., J. Kren and E. van der Marel (2018), The cost of data protection, Vox EU CEPR, https://voxeu.org/article/cost-data-protectionism.

G20 (2020), Communiqué - G20 Finance Ministers \& Central Bank Governors Meeting, https://g20.org/en/media/Documents/FMCBG\%20Communiqu\%C3\%A9 English 14October2 $020700 \mathrm{pm} . \mathrm{pdf}$.

G20 (2018), G20 Argentina - G20 Digital Economy Ministerial Declaration, http://www.g20.utoronto.ca/2018/2018-08-24-digital ministerial declaration salta.pdf (accessed on 22 February 2021).

G20 (2015), Introductory note to the G20 anti-corruption open data principles, http://www.g20.utoronto.ca/2015/G20-Anti-Corruption-Open-Data-Principles.pdf. 
Galasso, A. and M. Schankerman (2015), "Patents and Cumulative Innovation: Causal Evidence from the Courts", The Quarterly Journal of Economics, Vol. 130/1, pp. 317-369.

Galasso, A. and M. Schankerman (2010), "Patent Thickets, Courts and the Market for Innovation", RAND Journal of Economics, Vol. 41, pp. 472-503.

Galasso, V. and M. Foucault (2020), "Working during COVID-19: Cross-country evidence from real-time survey data", OECD Social, Employment and Migration Working Papers, No. 246, OECD Publishing, Paris, https://dx.doi.org/10.1787/34a2c306-en.

Gal, P. et al. (2019), "Digitalisation and productivity: In search of the holy grail - Firm-level empirical evidence from EU countries", International Productivity Monitor Number 37, Fall 2019.

Gal, P. and W. Witheridge (2019), "Productivity and innovation at the industry level: What role for integration in global value chains?", OECD Productivity Working Papers, No. 19, OECD Publishing, Paris, https://dx.doi.org/10.1787/a5cec52c-en.

Gavosto, A. and B. Romano (2020), "The impact of the COVID-19 pandemic on the Italian schools and universities: The challenge of distance learning", in Bellettini, G. and A. Goldstein (eds.), The Italian economy after COVID-19: Short-term costs and long-term adjustments, Bonomia University Press, Bologna.

Goldfarb, A. and C. Tucker (2019), "Digital Economics", Journal of Economic Literature, Vol. 57/1, pp. 3-43, http://dx.doi.org/10.1257/jel.20171452.

Gourdon, H. (2020), Un nouveau record de créations d'entreprises en 2020 malgré la crise sanitaire, Insee Première $n^{\circ} 1837$, https://www.insee.fr/fr/statistiques/5016913\#onglet-2 (accessed on 12 March 2021).

Grundke, R. et al. (2017), "Having the right mix: The role of skill bundles for comparative advantage and industry performance in GVCs", OECD Science, Technology and Industry Working Papers, No. 2017/03, OECD Publishing, Paris, https://dx.doi.org/10.1787/892a4787en.

Grundke, R. et al. (2018), "Which skills for the digital era?: Returns to skills analysis", OECD Science, Technology and Industry Working Papers, No. 2018/09, OECD Publishing, Paris, https://dx.doi.org/10.1787/9a9479b5-en.

Hall, B. (2009), "Innovation and Diffusion", in The Oxford Handbook of Innovation, Oxford University Press, http://dx.doi.org/10.1093/oxfordhb/9780199286805.003.0017.

Halpern, L., M. Koren and A. Szeidl (2015), "Imported inputs and productivity", American Economic Review, Vol. 105/12, pp. 3660-3703, http://dx.doi.org/10.1257/aer.20150443.

Haskel, J. and S. Westlake (2018), Capitalism without Capital: The Rise of the Intangible Economy, Princeton University Press.

Heller, M. and R. Eisenberg (1998), Can patents deter innovation? The anticommons in biomedical research, American Association for the Advancement of Science, http://dx.doi.org/10.1126/science.280.5364.698.

Hornstein, A. and P. Krusell (1996), "Can Technology Improvements Cause Productivity Slowdowns?”, NBER Macroeconomics Annual, Vol. 11, http://dx.doi.org/10.1086/654303. 
Hottenrott, H. and C. Lopes-Bento (2014), "(International) R\&D collaboration and SMEs: The effectiveness of targeted public R\&D support schemes”, Research Policy, Vol. 43/6, pp. 10551066.

Hupkau, C. et al. (2020), Labour market shocks during the Covid-19 pandemic: inequalities and child outcomes, Centre for Economic Performance, https://cep.Ise.ac.uk/pubs/download/cepcovid-19-015.pdf.

ILO (2021), ILO Monitor: COVID-19 and the world of work..

Katz., L. et al. (2020), Why Do Sectoral Employment Programs Work? Lessons From Workadvance, NBER Working Paper, http://dx.doi.org/10.3386/w28248.

Klenow, P. and H. Li (2020), Innovative Growth Accounting, University of Chicago Press.

López González, J. et al. (2019), "Participation and benefits of SMEs in GVCs in Southeast Asia", OECD Trade Policy Papers, No. 231, OECD Publishing, Paris, https://dx.doi.org/10.1787/3f5f2618-en.

López-Gurrero, M. (2020), Beyond the Classroom Walls: An opportunity for an inclusive digitalisation of education, The OECD Forum Network, https://www.oecdforum.org/posts/beyond-the-classroom-walls-an-opportunity-for-an-inclusive-digitalisation-ofeducation.

Mancini, J. (2019), Charting the way forward for digital competition policy, https://oecdonthelevel.com/2019/12/02/charting-the-way-forward-for-digital-competitionpolicy/ (accessed on 26 January 2021).

Mancini, J. (2019), "Digital antitrust: An emerging consensus?", https://www.concurrences.com No 4-2019, pp. 0-0.

Manpower (2020), Closing the skills gap: What workers want, Manpower Group, https://go.manpowergroup.com/hubfs/MPG WhatWorkersWant 2020.pdf?hsLang=en.

Manpower (2020), Talent Shortage by Company Size, https://go.manpowergroup.com/talentshortage.

Mateut, S. (2018), "Subsidies, financial constraints and firm innovative activities in emerging economies", Small Business Economics, Vol. 50, pp. 131-162.

Mazzucato, M. (2015), "The Entrepreneurial State", in The Entrepreneurial State: Debunking Public vs. Private Sector Myths, Anthem Press, https://books.google.fr/books?id=LznCgAAQBAJ.

McKinsey (2020), How COVID-19 has pushed companies over the technology tipping point-and transformed business forever, https://www.mckinsey.com/business-functions/strategy-andcorporate-finance/our-insights/how-covid-19-has-pushed-companies-over-the-technologytipping-point-and-transformed-business-forever.

McKinsey (2016), Unlocking Indonesia’s Digital Oportunity, McKinsey \& Company.

MGI (2016), Digital Globalisation: The New Era of Global Flows, McKinsey Global Institute, https://www.mckinsey.com/business-functions/mckinsey-digital/our-insights/digitalglobalization-the-new-era-of-global-flows. 
Moser, P. (2013), "Patents and Innovation: Evidence from Economic History", Journal of Economic Perspective, Vol. 27/1, pp. 23-44.

Moser, P. (2005), "How Do Patent Laws Infl uence Innovation? Evidence from NineteenthCentury World's Fairs", American Economic Review, Vol. 95/4, pp. 1215-36.

Nedelkoska, L. and G. Quintini (2018), "Automation, skills use and training", OECD Social, Employment and Migration Working Papers, No. 202, OECD Publishing, Paris, https://dx.doi.org/10.1787/2e2f4eea-en.

Nicoletti, G., C. von Rueden and D. Andrews (2020), "Digital technology diffusion: A matter of capabilities, incentives or both?", European Economic Review, Vol. 128, p. 103513, http://dx.doi.org/10.1016/..euroecorev.2020.103513.

Nordhaus, W. (1969), Invention, Growth, and Welfare: A Theoretical Treatment of Technological, MIT Press, Cambridge MA.

OECD (2021), Bridging the gap in the financing of intangibles to support productivity: A policy toolkit, OECD Publishing, Paris (forthcoming).

OECD (2021), Bridging the gap in the financing of intangibles to support productivity: Background paper, OECD Publishing, Paris (forthcoming).

OECD (2021), Data portability, interoperability and competition - Background note, OECD, Paris, https://www.oecd.org/daf/competition/data-portability-interoperability-and-competition.htm (accessed on 3 June 2021).

OECD (2021), Delivering Quality Education and Health Care to All: Preparing Regions for Demographic Change, OECD Rural Studies, OECD Publishing, Paris, https://dx.doi.org/10.1787/83025c02-en.

OECD (2021), Dissecting online platform diffusion's patterns and drivers: Background paper, OECD contribution to the Framework Working Group of the 2021 G20 Presidency.

OECD (2021), Fostering economic resilience in a world of open and integrated markets: Risks, vulnerabilities and areas for policy action, Report Prepared for the 2021 UK Presidency of the G7.

OECD (2021), Good Practice Principles for Data Ethics in the Public Sector, OECD Publishing (forthcoming).

OECD (2021), Harnessing the producitivty benefits of online platforms: Backgrond paper, OECD contribution to the Framework Working Group of the 2021 G20 Presidency.

OECD (2021), Improving the Quality of Non-Formal Adult Learning: Learning from European Best Practices on Quality Assurance, Getting Skills Right, OECD Publishing, Paris, https://dx.doi.org/10.1787/f1b450e1-en.

OECD (2021), OECD Science, Technology and Innovation Outlook 2021: Times of Crisis and Opportunity, OECD Publishing, Paris, https://dx.doi.org/10.1787/75f79015-en.

OECD (2021), Recommendation of the Council on Broadband Connectivity, OECD Publishing.

OECD (2021), Tackling the COVID-19 outbreak: Reinforcing the digital transformation of the public sector, OECD Policy Responses to Coronavirus (COVID-19), forthcoming. 
OECD (2021), The Digital Transformation of SMEs, OECD Studies on SMEs and

Entrepreneurship, OECD Publishing, Paris, https://dx.doi.org/10.1787/bdb9256a-en.

OECD (2021), The Human Side of Productivity, Global Forum on Productivity (forthcoming).

OECD (2021), The Impact of the Growth of the Sharing and Gig Economy on VAT/GST Policy and Administration, OECD, http://dx.doi.org/10.1787/51825505-en.

OECD (2021), The role of online platforms in weathering the COVID-19 shock, OECD Policy Responses to Coronavirus (COVID-19), http://www.oecd.org/coronavirus/policyresponses/the-role-of-online-platforms-in-weathering-the-covid-19-shock-2a3b8434/.

OECD (2020), Abuse of Dominance in Digital Markets, http://www.oecd.org/daf/competition/abuse-of-dominance-in-digital-markets-2020.pdf (accessed on 30 November 2020).

OECD (2020), Capacity for remote working can affect shutdowns' costs differently across places, OECD Policy Responses to Coronavirus (COVID-19), http://www.oecd.org/coronavirus/policyresponses/capacity-for-remote-working-can-affect-lockdown-costs-differently-across-places$\underline{0 \mathrm{e} 85740 \mathrm{e} / .}$.

OECD (2020), Combatting COVID-19's effect on children, OECD Policy Responses to Coronavirus (COVID-19), http://www.oecd.org/coronavirus/policy-responses/combattingcovid-19-s-effect-on-children-2e1f3b2f/.

OECD (2020), Competition Economics of Digital Ecosystems, https://www.oecd.org/daf/competition/competition-economics-of-digital-ecosystems.htm (accessed on 26 January 2021).

OECD (2020), Consumer Data Rights and Competition - Background Note, OECD Publishing, Paris, https://www.oecd.org/daf/competition/consumer-data-rights-and-competition.htm (accessed on 30 August 2020).

OECD (2020), COVID-19 and global value chains: Policy options to build more resilient production networks, http://www.oecd.org/coronavirus/policy-responses/covid-19-and-globalvalue-chains-policy-options-to-build-more-resilient-production-networks-04934ef4/ (accessed on 15 December 2020).

OECD (2020), "Digital Government Index: 2019 results", OECD Public Governance Policy Papers, No. 03, OECD Publishing, Paris, https://dx.doi.org/10.1787/4de9f5bb-en.

OECD (2020), E-commerce in the times of COVID-19, OECD Policy Responses to Coronavirus (COVID-19), https://read.oecd-ilibrary.org/view/?ref=137 137212-t0fjgnerdb\&title=Ecommerce-in-the-time-of-COVID-19.

OECD (2020), Education at a Glance 2020: OECD Indicators, OECD Publishing, Paris, https://dx.doi.org/10.1787/69096873-en.

OECD (2020), Increasing Adult Learning Participation: Learning from Successful Reforms, Getting Skills Right, OECD Publishing, Paris, https://dx.doi.org/10.1787/cf5d9c21-en.

OECD (2020), Insolvency and debt overhang following the COVID-19 outbreak: Assessment of risks and policy responses, OECD Publishing, Paris, https://dx.doi.org/10.1787/7806f078-en. 
OECD (2020), Insolvency and debt overhang following the COVID-19 outbreak: Assessment of risks and policy responses, OECD Publishing, Paris, https://dx.doi.org/10.1787/7806f078-en.

OECD (2020), Insolvency and debt overhang following the COVID-19 outbreak: Assessment of risks and policy responses, OECD Publishing, Paris, https://dx.doi.org/10.1787/7806f078-en.

OECD (2020), Insolvency and debt overhang following the COVID-19 outbreak: Assessment of risks and policy responses, OECD Publishing, Paris, https://dx.doi.org/10.1787/7806f078-en.

OECD (2020), Keeping the Internet up and running in times of crisis, http://www.oecd.org/coronavirus/policy-responses/keeping-the-internet-up-and-running-intimes-of-crisis-4017c4c9/ (accessed on 9 October 2020).

OECD (2020), Lessons for Education from COVID-19: A Policy Maker's Handbook for More Resilient Systems, OECD Publishing, Paris, https://dx.doi.org/10.1787/0a530888-en.

OECD (2020), Model Rules for Reporting by Platform Operators with respect to Sellers in the Sharing and Gig Economy, OECD Publishing, Paris, https://www.oecd.org/tax/exchange-oftax-information/model-rules-for-reporting-by-platform-operators-with-respect-to-sellers-in-thesharing-and-gig-economy.htm (accessed on 30 August 2020).

OECD (2020), OECD Digital Economy Outlook 2020, OECD Publishing, Paris, https://dx.doi.org/10.1787/bb167041-en.

OECD (2020), OECD Economic Outlook, Volume 2020 Issue 2, OECD Publishing, Paris, https://dx.doi.org/10.1787/39a88ab1-en.

OECD (2020), OECD Employment Outlook 2020: Worker Security and the COVID-19 Crisis, OECD Publishing, Paris, https://dx.doi.org/10.1787/1686c758-en.

OECD (2020), OECD Regions and Cities at a Glance 2020, OECD Publishing, Paris, https://dx.doi.org/10.1787/959d5ba0-en.

OECD (2020), Productivity gains from teleworking in the post COVID-19 era : How can public policies make it happen?, OECD Policy Responses to Coronavirus (COVID-19), https://www.oecd.org/coronavirus/policy-responses/productivity-gains-from-teleworking-inthe-post-covid-19-era-a5d52e99/.

OECD (2020), Public Procurement and Infrastructure Governance: Initial policy responses to the Coronavirus (COVID-19) crisis, https://read.oecd-ilibrary.org/view/?ref=135 135391eb6wiwbrmn\&title=Public-Procurement-And-Infrastructure-Governance.

OECD (2020), Seven lessons learned about digital security risk during the COVID-19 crisis, OECD Publishing.

OECD (2020), Start-ups in the time of COVID-19: Facing the challenges, seizing the opportunities, http://www.oecd.org/coronavirus/policy-responses/start-ups-in-the-time-ofcovid-19-facing-the-challenges-seizing-the-opportunities-87219267/ (accessed on 12 December 2020).

OECD (2020), Start-ups, Killer Acquisitions and Merger Control, http://www.oecd.org/daf/competition/start-ups-killer-acquisitions-and-merger-control.htm (accessed on 9 September 2020). 
OECD (2020), Supporting businesses in financial distress to avoid insolvency during the COVID19 crisis, OECD Policy Responses to Coronavirus (COVID-19), http://www.oecd.org/coronavirus/policy-responses/supporting-businesses-in-financialdistress-to-avoid-insolvency-during-thecovid-19-crisis-b4154a8b/.

OECD (2020), Tax Challenges Arising from Digitalisation - Economic Impact Assessment: Inclusive Framework on BEPS, OECD/G20 Base Erosion and Profit Shifting Project, OECD Publishing, Paris, https://dx.doi.org/10.1787/0e3cc2d4-en.

OECD (2020), Tax Challenges Arising from Digitalisation - Report on Pillar One Blueprint: Inclusive Framework on BEPS, OECD/G20 Base Erosion and Profit Shifting Project, OECD Publishing, Paris, https://dx.doi.org/10.1787/beba0634-en.

OECD (2020), Tax Challenges Arising from Digitalisation - Report on Pillar Two Blueprint: Inclusive Framework on BEPS, OECD/G20 Base Erosion and Profit Shifting Project, OECD Publishing, Paris, https://dx.doi.org/10.1787/abb4c3d1-en.

OECD (2020), The firm-level link between productivity dispersion and wage inequality: A symptom of low job monility?, ECO/CPE/WP1(2020)20.

OECD (2020), The impact of COVID-19 on student equity and inclusion: Supporting vulnerable students during school closures and school re-openings, OECD Publishing, Paris, https://dx.doi.org/10.1787/d593b5c8-en.

OECD (2020), The impact of COVID-19 on student equity and inclusion: Supporting vulnerable students during school closures and school re-openings, OECD Publishing, Paris, https://dx.doi.org/10.1787/d593b5c8-en.

OECD (2020), "The OECD Digital Government Policy Framework: Six dimensions of a Digital Government", OECD Public Governance Policy Papers, No. 02, OECD Publishing, Paris, https://dx.doi.org/10.1787/f64fed2a-en.

OECD (2020), The potential of online learning for adults: Early lessons from the COVID-19 crisis, OECD Policy Responses to Coronavirus (COVID-19), http://www.oecd.org/coronavirus/policyresponses/the-potential-of-online-learning-for-adults-early-lessons-from-the-covid-19-crisisee040002/.

OECD (2019), Enhancing Access to and Sharing of Data: Reconciling Risks and Benefits for Data Re-use across Societies, OECD Publishing, Paris, https://dx.doi.org/10.1787/276aaca8en.

OECD (2019), Getting Skills Right: Future-Ready Adult Learning Systems, Getting Skills Right, OECD Publishing, Paris, https://dx.doi.org/10.1787/9789264311756-en.

OECD (2019), Going Digital: Shaping Policies, Improving Lives, OECD Publishing, Paris, https://dx.doi.org/10.1787/9789264312012-en.

OECD (2019), How's Life in the Digital Age?: Opportunities and Risks of the Digital Transformation for People's Well-being, OECD Publishing, Paris, https://dx.doi.org/10.1787/9789264311800-en.

OECD (2019), Measuring the Digital Transformation: A Roadmap for the Future, OECD Publishing, Paris, https://dx.doi.org/10.1787/9789264311992-en. 
OECD (2019), OECD Compendium of Productivity Indicators 2019, OECD Publishing, Paris, https://dx.doi.org/10.1787/b2774f97-en.

OECD (2019), OECD Economic Surveys: China 2019, OECD Publishing, Paris, https://dx.doi.org/10.1787/eco surveys-chn-2019-en.

OECD (2019), OECD Economic Surveys: India 2019, OECD Publishing, Paris, https://dx.doi.org/10.1787/554c1c22-en.

OECD (2019), OECD Future of Education and Skills 2030 Concept Note: Skills for 2030, https://www.oecd.org/education/2030-project/teaching-and-learning/learning/all-conceptnotes/ (accessed on 14 January 2021).

OECD (2019), OECD Regional Outlook 2019: Leveraging Megatrends for Cities and Rural Areas, OECD Publishing, Paris, https://dx.doi.org/10.1787/9789264312838-en.

OECD (2019), OECD Skills Outlook 2019 : Thriving in a Digital World, OECD Publishing, Paris, https://dx.doi.org/10.1787/df80bc12-en.

OECD (2019), OECD SME and Entrepreneurship Outlook 2019, OECD Publishing, Paris, https://dx.doi.org/10.1787/34907e9c-en.

OECD (2019), PISA 2018 - Insights and Interpretations, https://www.oecd.org/pisa/PISA\%202018\%20Insights\%20and\%20Interpretations\%20FINAL\% 20PDF.pdf.

OECD (2019), Preparing for the Changing Nature of Work, https://www.oecd.org/goingdigital/changing-nature-of-work-in-the-digital-era.pdf.

OECD (2019), Recommendation on Digital Security of Critical Activities, OECD Publishing.

OECD (2019), The Path to Becoming a Data-Driven Public Sector, OECD Digital Government Studies, OECD Publishing, Paris, https://dx.doi.org/10.1787/059814a7-en.

OECD (2019), "The road to 5G networks: Experience to date and future developments", OECD Digital Economy Papers, No. No. 284, OECD, https://www.oecd-ilibrary.org/science-andtechnology/the-road-to-5g-networks 2f880843-en (accessed on 13 January 2021).

OECD (2019), "Vertical Mergers in the Technology, Media and Telecom Sector", https://one.oecd.org/document/DAF/COMP(2019)5/en/pdf.

OECD (2018), PISA 2018 Results (Volume V): Effective Policies, Successful Schools, PISA, OECD Publishing, Paris, https://dx.doi.org/10.1787/ca768d40-en.

OECD (2018), Quality considerations in digital zero-price markets, http://www.oecd.org/daf/competition/quality-considerations-in-the-zero-price-economy.htm (accessed on 26 January 2021).

OECD (2018), Rethinking Antitrust Tools for Multi-Sided Platforms 2018, OECD Publishing, https://www.oecd.org/daf/competition/rethinking-antitrust-tools-for-multi-sided-platforms.htm.

OECD (2017), Algorithms and Collusion: Competition Policy in the Digital Age, http://www.oecd.org/competition/algorithms-collusion-competition-policy-in-the-digitalage.htm. 
OECD (2017), OECD Economic Surveys: Italy 2017, OECD Publishing, Paris.

OECD (2017), OECD Telecommunication and Broadcasting Review of Mexico 2017, OECD

Publishing, Paris, https://dx.doi.org/10.1787/9789264278011-en.

OECD (2016), Big Data: Bringing Competition Policy to the Digital Era, OECD, https://one.oecd.org/document/DAF/ COMP(2016)14/en/pdf.

OECD (2016), "New Skills for the Digital Economy: Measuring the demand and supply of ICT skills at work", OECD Digital Economy Papers, No. 258, OECD Publishing, Paris, https://dx.doi.org/10.1787/5j|wnkm2fc9x-en.

OECD (2016), "Skills for a Digital World: 2016 Ministerial Meeting on the Digital Economy Background Report", OECD Digital Economy Papers, No. 250, OECD Publishing, Paris, https://dx.doi.org/10.1787/5j|wz83z3wnw-en.

OECD (2015), Enquiries Into Intellectual Property's Economic Impact, OECD Publishing.

OECD (2015), OECD Science, Technology and Industry Scoreboard 2015: Innovation for growth and society, OECD Publishing, Paris, https://dx.doi.org/10.1787/sti scoreboard-2015-en.

OECD (2015), Students, Computers and Learning: Making the Connection, PISA, OECD Publishing, Paris, https://dx.doi.org/10.1787/9789264239555-en.

OECD (2014), Recommendation of the Council on Digital Government Strategies, OECD, Paris, https://legalinstruments.oecd.org/en/instruments/OECD-LEGAL-0406.

OECD (2013), Interconnected Economies: Benefiting from Global Value Chains, OECD Publishing, Paris, https://dx.doi.org/10.1787/9789264189560-en.

OECD (2013), New sources of growth: Knowledge-based capital, OECD Publishing.

OECD (2008), Monopsony and Buyer Power, Proceedings of a Roundtable on Monopsony and Buyer Power held by the OECD Competition Committee in October 2008, https://www.oecd.org/daf/competition/44445750.pdf.

Olson, P. (2015), "Exclusive: The Rags-To-Riches Tale Of How Jan Koum Built WhatsApp Into Facebook's New \$19 Billion Baby", Forbes, https://www.forbes.com/sites/parmyolson/2014/02/19/exclusive-inside-story-how-jan-koumbuilt-whatsapp-into-facebooks-new-19-billion-baby/\#70442bc82fa1 (accessed on 1 September 2020).

OPSI (2020), OPSI COVID-19 Innovative Response Tracker, https://oecd-opsi.org/responsebadge/open-data/.

Oreopoulos, P., T. von Wachter and A. Heisz (2012), "The Short- and Long-Term Career Effects of Graduating in a Recession", American Economic Journal: Applied Economics, Vol. 4/1, pp. 1-29, http://dx.doi.org/10.1257/app.4.1.1.

Perez, C. and A. Vourc'h (2020), "Individualising training access schemes: France - the Compte Personnel de Formation (Personal Training Account - CPF)", OECD Social, Employment and Migration Working Papers, No. 245, OECD Publishing, Paris, https://dx.doi.org/10.1787/301041f1-en. 
Pilat, D. and C. Criscuolo (2018), "The Future of Productivity what contribution can digital transformation make?”, Policy Quarterly, Vol. 14/3, pp. 10-16.

Psacharopoulos, G. et al. (2020), The COVID-19 cost of school closures, World Bank Blogs, https://blogs.worldbank.org/education/covid-19-cost-school-closures (accessed on 4 February 2021).

PWC (2020), COVID-19 has accelerated customer demand for cloud-based offerings, https://www.pwc.com/us/en/industries/tmt/library/covid19-cloud-infrastructure.html (accessed on 16 December 2020).

République Française (2018), Liste Publique des Organismes de Formation (L.6351-7-1 du Code du Travail), https://www.data.gouv.fr/fr/datasets/liste-publique-des-organismes-deformationl-6351-7-1-du-code-du-travail/.

Ristuccia, C. and S. Solomou (2014), "Can general purpose technology theory explain economic growth? Electrical power as a case study", European Review of Economic History, Vol. 18/3, pp. 227-247, http://dx.doi.org/10.1093/ereh/heu008.

Rosenberg, N. (1972), "Factors Affecting the Diffusion of Technology", Explorations in Economic History, Vol. 10/1, https://search.proquest.com/openview/65fba4ea2889158b17b6e92e83224a6a/1?cbl=181932 6\&pq-origsite $=$ gscholar (accessed on 10 December 2020).

Ruiz-Valenzuela, J. (2020), "Intergenerational effects of employment protection reforms", Labour Economics, Vol. 62, p. 101774, http://dx.doi.org/10.1016/j.labeco.2019.101774.

Sampat, B. and H. Williams (2019), "How Do Patents Affect Follow-On Innovation? Evidence from the Human Genome", American Economic Review, Vol. 109/1, pp. 203-26.

Schleicher, A. (2020), Advancing schooling beyond coronavirus - new insights from PISA, Blogpost - OECD Education and Skills Today, https://oecdedutoday.com/advancingschooling-beyond-coronavirus-new-insights-from-pisal.

Schwellnus, C. et al. (2019), "Gig economy platforms: Boon or Bane?”, OECD Economics Department Working Papers, No. 1550, OECD Publishing, Paris, https://dx.doi.org/10.1787/fdb0570b-en.

Sorbe, S. et al. (2019), "Digital Dividend: Policies to Harness the Productivity Potential of Digital Technologies", OECD Economic Policy Papers, No. 26, OECD Publishing, Paris, https://dx.doi.org/10.1787/273176bc-en.

Sorbe, S. and Å. Johansson (2017), "International tax planning, competition and market structure", OECD Economics Department Working Papers, No. 1358, OECD Publishing, Paris, https://dx.doi.org/10.1787/e9c35474-en.

Spiezia, V. and J. Tscheke (2020), "International agreements on cross-border data flows and international trade: A statistical analysis", OECD Science, Technology and Industry Working Papers, No. 2020/09, OECD Publishing, Paris, https://dx.doi.org/10.1787/b9be6cbf-en.

Squicciarini, M. and H. Nachtigall (2021), "Demand for Al skills in jobs: Evidence from online job postings", OECD Science, Technology and Industry Working Papers, No. 2021/03, OECD Publishing, Paris, https://dx.doi.org/10.1787/3ed32d94-en. 
Squicciarini, M. and L. Samek (forthcoming), The Role of Innovation and Human Capital for the Productivity of Industries, https://one.oecd.org/document/DSTI/CIIE/WPIA(2020)7/en/pdf.

Syverson, C. (2011), "What Determines Productivity?", Journal of Economic Literature, Vol. 49/2, pp. 326-365, http://dx.doi.org/10.1257/jel.49.2.326.

The Economist (2020), When big isn't beautiful: What more should antitrust be doing?, https://www.economist.com/schools-brief/2020/08/06/what-more-should-antitrust-be-doing.

UN/DESA (2020), Policy Brief \#61: COVID-19: Embracing digital government during the pandemic and beyond, United Nations, https://www.un.org/development/desa/dpad/publication/un-desa-policy-brief-61-covid-19embracing-digital-government-during-the-pandemic-and-beyond/.

UNESCO (2020), Education: From disruption to recovery, https://en.unesco.org/covid19/educationresponse.

UNESCO (2019), 4th Global Report on Adult Learning and Education, UNESCO Institute for Lifelong Learning, https://uil.unesco.org/system/files/grale 4 final.pdf.

United States International Trade Commission (2014), Digital Trade in the U.S. and Global Economies, Part 2, United States International Trade Commission, Washington, DC.

van der Marel, E., H. Lee-Makiyama and M. Bauer (2014), The Costs of Data Localisation: A Friendly Fire on Economic Recovery /, European Centre for International political Economy, https://ecipe.org/publications/dataloc/ (accessed on 23 April 2021).

Windisch, H. (2015), "Adults with low literacy and numeracy skills: A literature review on policy intervention", OECD Education Working Papers, No. 123, OECD Publishing, Paris, https://dx.doi.org/10.1787/5jrxnjdd3r5k-en.

Wolf, N. (2010), "Europe's Great Depression: coordination failure after the First World War", Oxford Review of Economic Policy, Vol. 26/3, pp. 339-369, http://dx.doi.org/10.1093/oxrep/gra022.

World Economic Forum (2020), A Roadmap for CrossBorder Data Flows: Future-Proofing Readiness and Cooperation in the New Data Economy, World Economci Forum, Geneva, https://www.weforum.org/whitepapers/a-roadmap-for-crossborder-data-flows-future-proofingreadiness-and-cooperation-in-the-new-data-economy (accessed on 22 April 2021).

World Economic Forum (2020), Data Free Flow with Trust (DFFT), World Economic Forum, http://www3.weforum.org/docs/WEF Paths Towards Free and Trusted Data\%20 Flows 2 020.pdf.

World Economic Forum (2020), Exploring International Data Flow Governance, World Economic Forum White Paper, http://www3.weforum.org/docs/WEF Trade Policy Data Flows Report.pdf. 